\title{
Climate and geology - a Phanerozoic perspective
}

\author{
ALAN P.M. VAUGHAN \\ British Antarctic Survey, High Cross, Madingley Rd, Cambridge CB3 0ET, e-mail: a.vaughan@bas.ac.uk
}

No of words in text: 19,106

No of references: 614

No of tables: 2

No of figures: 8

Running Title: Phanerozoic climates 


\section{Abstract}

The Phanerozoic is over 540 million years long, and, with its defining accompaniment of abundant complex life, provides us with a unique perspective on the extremes of climate change. Understanding these extremes is particularly important if we are to anticipate the possible effects of global warming. The broad sweep of climate change through the Phanerozoic began with relatively cool global temperatures and recovery from late Proterozoic glaciation. This was followed by a mid Cambrian to Ordovician episode of relatively warm global climate, after which global climate cooled, culminating in the major glaciations of the Carboniferous and Permian periods. The Triassic and Early Jurassic were warm. The Late Jurassic-Early Cretaceous period was cool, although without full global glaciation. Global temperatures peaked in the mid-Cretaceous. Since then global climates have cooled, culminating in Neogene glaciation. These $\sim 100$ million year trends in overall climate show short intense excursions of contrasting climate, many of which have been associated with the mass extinction of life, and with major volcanic and tectonic events. This chapter argues that, through the Phanerozoic, two overlapping stable climate regimes appear to have dominated: a high- $\mathrm{CO}_{2}$ ( $>1000$ ppmv), largely warm climate regime, punctuated by many short-lived episodes of glaciation; and a low- $\mathrm{CO}_{2}(<1000 \mathrm{ppmv})$, largely cool regime, marked by protracted episodes of superglaciation.

As Hay et al. (1997) pointed out, "the climate of the Holocene is not well-suited to be the baseline climate of the planet". This is particularly important in light of predicted changes to the global climate anticipated as a result of global warming (Hay et al. 1997; IPCC 2001). To understand what may happen we must examine and try to simulate the warm and cool climates of the more distant past, ideally of the whole Phanerozoic (Fig. 1). The most 
complete summary of Phanerozoic warm and cool climates continues to be Frakes et al. (1992), based on geological evidence from the rock record and oxygen isotopes. They subdivided Phanerozoic time into palaeoclimate "modes" (Table 1; Fig. 1a), independent of geological timescale boundaries, improving on the chronostratigraphic system by system treatment by Frakes (1979). These "modes" are still valid and useful today, although Barron (1993) pointed out that they may represent oversimplifications. For example, Barron (1993) argued that Frakes et al. (1992) placed the Pliocene warm interval, currently the focus of much study to understand the possible effects of global warming (e.g. Haywood et al. 2005; Barreiro et al. 2006), in one of their cold modes. Barron (1993) also contended that they grouped quite dissimilar Late Cretaceous and Early Eocene warm intervals together in the same warm mode. In this chapter, the warm and cool climate modes of Frakes et al. (1992) will be reviewed in time-sequential order, and only developments or changes since their synthesis will be covered in any detail.

Between 1992 and the advent of this book there have been several reviews of aspects of the Phanerozoic palaeoclimate record, although none on the scale of Frakes et al. (1992). The volume edited by Walliser (1995) reviewed global event stratigraphy for the Phanerozoic, which includes many aspects of climate change. Crowell (1999) examined the implications of pre-Mesozoic ice ages on our understanding of the climate system, and Huber et al. (2000) specifically treated former warm climates. Boucot \& Gray (2001) assessed Phanerozoic climate models based on atmospheric $\mathrm{CO}_{2}$, and reviewed the many $\mathrm{CO}_{2}$ proxies, with a particular emphasis on soil and soil-forming organisms. Wallmann (2001) has come closest to the treatment by Frakes et al. (1992) and used the record of marine $\delta^{18} \mathrm{O}$ values to subdivide the Phanerozoic. He identified three combined icehouse-greenhouse cycles with durations of approximately 127 My between the Cambrian and the Triassic, followed by a 
longer cycle spanning the Jurassic to Cenozoic, which largely correspond to the climate modes proposed by Frakes et al. (1992) and discussed in this chapter. Subsequently, Wallmann (2004) used a multi-proxy approach to model Phanerozoic climates and identify warm and cool climate epochs based on $\mathrm{CO}_{2}$ levels, proposing a link with the intensity of the galactic cosmic ray flux.

\section{Palaeoclimate proxies}

We cannot directly observe the climates of the geological past in the way that we have been able to observe climate parameters since the $17^{\text {th }}$ century (e.g. Plaut et al. 1995). The key variables, which are both physical and chemical, and include temperature, atmospheric composition and seawater salinity, cannot be measured directly. We depend on chemical and biological systems that have responded, hopefully systematically, to changes in climate, and which have left a record in sediments and ice, which if not pristine, has at least been altered in a systematic way. These so-called proxy data, proxies for short, can be interpreted to yield numerical and qualitative data for the key variables of former climates in the geological past (e.g. Wefer et al. 1999). Proxies must be evaluated carefully and the level of confidence in a proxy can change as the factors affecting its reliability are better understood (e.g. Elderfield 2002; Williams et al. 2005). Geological proxies, i.e. those based on sedimentary facies such as coal or evaporites, can appear relatively straightforward to interpret but may introduce a bias in the signal through incompleteness of the stratigraphic record. There are also parallel factors, such that often only extreme events get preserved, and that preservation of ordinary events often requires peculiarities of tectonic setting (for a discussion of some of these caveats see Sellwood et al. 1993). It is useful to think of the tides in this respect and when or where today the constant shifting of sand on an average beach might be preserved to record a 
shoreline. Even in tectonically active areas, such as the western margin of the Americas, earthquakes that shift the base level, such as the 1960 Chile earthquake (e.g. Cisternas et al. 2005), or the 1964 Alaska earthquake (e.g. Hamilton et al. 2005), happen only once every few hundred years along any particular section of coastline. Therefore, of the order of 150,000 tidal events may go unrecorded, with only the last tides preceding a major earthquake having a chance of preservation. By comparison, chemical and palaeontological methods of estimating Phanerozoic palaeoclimate are complex to interpret, but, and certainly in the case of oceanic records, they can offer better guarantees of completeness, at least back into the Jurassic.

In the sections below, proxies are reviewed (summarized in Table 2) and organised according to the way that proxies are grouped within particular subdisciplines. Chemistry-based proxies are the most abstract and tend to focus on the chemical or isotopic system applied. These are grouped by parameter estimated. Lithological proxies are the most directly related to the parameter estimated and are grouped by rock type, mineralogy or facies interpreted. Palaeontological proxies are subdivided by whether they use taxonomic methods or focus on some morphological aspect of a group of organisms. For clarity and ease of reference, all the proxies reviewed are grouped by parameter estimated in Table 2 .

\section{Chemistry-based proxies.}

Chemistry-based palaeoclimate proxy studies were made possible by the stable isotope work of Harold Urey and others in the 1940's and 1950's (Urey 1947; Epstein et al. 1953). Emiliani (1955) published the first quantitative Pleistocene palaeotemperature curve based on the new $\delta^{18} \mathrm{O}$ palaeothermometer. This work was substantially built upon by Shackleton and others (Shackleton 1965; Shackleton \& Opdyke 1973; Shackleton \& Kennett 1975; 
Shackleton 1977), culminating in the enormous success of the CLIMAP project in the 1970's (CLIMAP 1981). Table 2 summarizes chemical proxies based on isotope-, element- and biogeochemistry-based systems.

Henderson (2002) has provided a useful framework for the treatment of chemistry-based oceanic proxies, which will form the basis for this section, though here applied to both oceanic and continental chemistry-based proxies. Henderson (2002) distinguished proxies that can be used to reconstruct the physical environment, such as palaeotemperature and mass flows, and those that can be used to reconstruct aspects of the carbon cycle, such as oceanic $\mathrm{pH}$ or atmospheric $\mathrm{CO}_{2}$ concentrations.

Palaeotemperature. Surface temperature is a reflection of time-averaged net solar energy input. This is energy that is not immediately reradiated back to space or involved in photosynthesis, but which is trapped for a time, either in the atmosphere via, for example, the greenhouse effect and hydrological cycle, e.g. evaporation and ice melting, or in the solid surface, lakes, seas and oceans. Surface temperature is the key variable for the Earth system. In the oceans, it drives the weather and winds, which ultimately power circulation in the atmosphere and oceans. On land and sea, it controls evaporation, which is a major influence on the water cycle and weathering.

As outlined above, $\delta^{18} \mathrm{O}$ in carbonate has been used as a surface palaeotemperature proxy since the 1950 's (e.g. Emiliani 1955). $\delta^{18} \mathrm{O}$ values are determined from skeletal and nonskeletal carbonates (Marshall 1992), with varying degrees of success, depending on whether the carbonate analysed is pristine or secondary. In marine settings $\delta^{18} \mathrm{O}$ ratios are derived from calcareous plankton, such as foraminifera or coccolithophores, as well as other marine 
invertebrates, such as brachiopods (Korte et al. 2005), corals, and various molluscs (e.g. Gazdzicki et al. 1992; Elorza et al. 1996; Bailey et al. 2003), and also bulk sediments (Tobin \& Walker 1997) and cements (Hays \& Grossman 1991). Marine records extend back to the Proterozoic (e.g. Samuelsson 1998). In terrestrial settings, speleothems (Winograd et al. 1992) provide a detailed record, as do lake-dwelling ostracods (Schwalb 2003) and gastropods (Grimes et al. 2003), although only extending back to the Pleistocene. Pedogenic carbonate provides a longer time record (e.g. Mack \& Cole 2005), although with significant gaps and problems of interpretation. Overall, interpretation of the signal from carbonate is complicated by, for example, the presence of cryptic species, such as in the foraminifera (e.g. Kucera \& Darling 2002), biological isotope fractionation during development, so called "vital effects" (e.g. Friedrich et al. 2006), and diagenesis (e.g. Wenzel et al. 2000; Williams et al. 2005). $\delta^{18} \mathrm{O}$ ratios can also be derived from non-calcareous sources, such as vertebrate tooth enamel (e.g. Bentaleb et al. 2006) and bone (e.g. Barrick et al. 1999), as well as fish scales and otoliths (e.g. Grimes et al. 2003), and diatom silica (e.g. Leng \& Barker 2006).

Other carbonate-based palaeotemperature proxies use the ratios of trace elements, such as foraminiferal $\mathrm{Mg} / \mathrm{Ca}$ (e.g. Elderfield 2002; Elderfield et al. 2002), coralline $\mathrm{Sr} / \mathrm{Ca}$ (e.g. Devilliers et al. 1994; Wei et al. 2004) and Li/Ca (Marriott et al. 2004), or Ca isotope ratios such as foraminiferal $\delta^{44} \mathrm{Ca}$ (e.g. Gussone et al. 2003). However, Ca isotope ratios have complex species-related variations in sensitivity (e.g. Sime et al. 2005) that complicate their usefulness. $\mathrm{Mg} / \mathrm{Ca}$ and $\mathrm{Sr} / \mathrm{Ca}$ from belemnites appears to be effective from the Late Cretaceous back to the Early Jurassic (Rosales et al. 2004).

More recent non-carbonate palaeotemperature proxies include the index of unsaturation of alkenones from the membranes of some Prymnesiophyceae algae (coccolithophores) such as 
Emiliania huxleyi (e.g. Prahl et al. 1988), the so-called UK'37 proxy. This proxy has proved to be very successful (e.g. Bard 2001), is effective back to the Miocene for marine sediments (e.g. Haywood et al. 2005), and has also been applied to lakes (Li et al. 1996). Oxidation effects needs to be considered for the older record (e.g. Hoefs et al. 1998). Amino acid racemization epimerization in molluscan calcite is another terrestrial palaeotemperature proxy (e.g. Murray-Wallace et al. 1988), which initially showed promise back to the Pliocene (e.g. Kaufman \& Brighamgrette 1993). However, recent studies have shown its application to be limited to the Late Pleistocene (e.g. Andersson et al. 2000). Similar to UK37', TEX86 is a palaeotemperature proxy based on the tetraether lipids of crenarcheota (Schouten et al. 2002). Initial results suggest that the proxy is robust (e.g. Wuchter et al. 2004). It appears to be resistant to post-depositional oxidation (e.g. Schouten et al. 2004) and is capable of recording palaeotemperatures above the $\sim 29^{\circ} \mathrm{C}$ limit of UK37' (e.g. Pelejero \& Calvo 2003; Schouten et al. 2003). TEX86 is also applicable to lakes (e.g. Powers et al. 2004), and it has an effective time range extending back to the Mesozoic (e.g. Schouten et al. 2003).

Palaeosalinity. Henderson (2002) highlighted palaeosalinity as a major environmental parameter for which we have no direct marine proxy. Calculations based on $\delta^{18} \mathrm{O}$ are prone to error (Schmidt 1999; Rohling 2000), but have been applied back to the Early Triassic (Korte et al. 2005). Recent developments suggest that U/Ca ratios in corals (Ourbak et al. 2006) and alkenone unsaturation ratios (Sikes \& Sicre 2002; Blanz et al. 2005; Schouten et al. 2006) show some promise.

Palaeocirculation of oceans. Palaeocirculation proxies either trace the movement of water masses or provide estimates of deep water flow (Henderson 2002). Of the former, $\delta^{13} \mathrm{C}$ (e.g. Lynch-Stieglitz \& Fairbanks 1994), Zn/Ca (e.g. Marchitto et al. 2000) and Cd/Ca (Boyle 1988) ratios in foraminiferal carbonate and ${ }^{9} \mathrm{Be} /{ }^{10} \mathrm{Be}$ ratios in manganese crusts (Kusakabe et 
al. 1987; vonBlanckenburg et al. 1996) trace water masses by mimicking nutrients. More recent tracers of water masses include isotopes of $\mathrm{Nd}$ and $\mathrm{Pb}$ (Ling et al. 1997), and $\mathrm{Hf}$ (David et al. 2001) mainly from ferromagnesian crusts on manganese nodules, but also from foraminifera (e.g. Vance \& Burton 1999), and Ag/Si ratios (Zhang et al. 2004). For deep water flow, radioactive proxies include ${ }^{14} \mathrm{C}$, and the U-series daughter products ${ }^{231} \mathrm{~Pa}$ and ${ }^{230} \mathrm{Th}$ (Henderson 2002). These have half-lives of less than $100 \mathrm{ky}$ (e.g. Edwards et al. 1997) and are really only applicable to the Pleistocene.

Sea-ice. IP25 (Belt et al. in press) is a proxy for palaeo-sea-ice distribution based on the distribution of $\mathrm{C} 25$ highly branched isoprenoid alkenes biosynthesised by diatoms living in sea-ice, notably genera of Haska and Rhizosolenia (Belt et al. 2006). The technique has so far been demonstrated in the Canadian Arctic for the Holocene (Belt et al. in press).

The carbon cycle. Understanding and quantifying the carbon cycle is key to determining the controls on past atmospheric $\mathrm{CO}_{2}$ (Henderson 2002). For long timescales, i.e. longer than a million years, the main control on atmospheric $\mathrm{CO}_{2}$ is the balance between volcanogenic gas output and net consumption by silicate weathering and carbonate deposition on the seafloor (Walker et al. 1981). For shorter timescales, the oceans (e.g. Henderson 2002), terrestrial vegetation (e.g. Schimel 1995) and soils (e.g. Schlesinger \& Andrews 2000) are likely to be the main controls. For example the oceans contain 50 to 60 times as much $\mathrm{CO}_{2}$ as the atmosphere (e.g. Henderson 2002; Barker et al. 2003). Quantifying, for example, the influence of the oceanic carbon cycle on atmospheric $\mathrm{CO}_{2}$ must take into account the four species of dissolved inorganic carbon, i.e. dissolved $\mathrm{CO}_{2}$, undissociated carbonic acid, bicarbonate ion and carbonate ion, by assessing the factors controlling the concentration of these species, in particular, productivity, nutrient utilization, carbonate alkalinity/weathering fluxes, and $\mathrm{pH}$ (Henderson 2002). Even in the modern era, the role of soils and terrestrial 
vegetation remains uncertain (House et al. 2003), this chapter will deal with the role of soils and vegetation in the section on lithological proxies below.

Palaeoproductivity. Biological productivity has the effect of removing carbon to depth from the surface oceans and the atmosphere. Biogenic barite has traditionally been used as a palaeoproductivity proxy because it sinks through the water column and enters the sedimentary record without much dissolution (e.g. Gingele \& Dahmke 1994). New palaeoproductivity proxies for the Pleistocene include the difference in solubility of $\mathrm{Th}, \mathrm{Pa}$, and Be (e.g. Chase et al. 2002), and sedimentary U concentration (e.g. Francois et al. 1997). Isotopic fractionation of transition metal isotopes by biological activity appears to select for lighter values (Zhu et al. 2002). The $\delta^{66} \mathrm{Zn}$ ratio of manganese crusts shows increasingly positive values with increasing bioproductivity (e.g. Maréchal et al. 2000). Fe isotopes (e.g. Beard et al. 1999) have proved so far ambiguous (e.g. Zhu et al. 2000). Zn/Si ratios in deep sea hexactinellid sponges increase with increasing rain of carbon as particulate matter from shallower oceanic levels, reflecting increased bioproductivity (Ellwood et al. 2004). Mo/Al ratios in black shales provide a palaeoproductivity proxy with a particularly long time range (e.g. Wilde et al. 2004). Rare earth element distribution coefficients in planktonic foraminifera also show promise as palaeoproductivity proxies (e.g. Haley et al. 2005). However, a recent intercomparison of palaeoproductivity proxies, particularly $\mathrm{Ba}$, has shown some significant interpretation problems (Averyt \& Paytan 2004).

Nutrient utilization. Water upwelling from the deep ocean carries with it nutrients and dissolved inorganic carbon. In areas of lower bioproductivity, some of this carbon is returned as $\mathrm{CO}_{2}$ to the upper oceans and atmosphere. This has been particularly true in the Southern Ocean (e.g. Sigman 2000). The three major biolimiting nutrients are phosphate, nitrate and 
silicate (Henderson 2002), with an increasing role being recognised for iron (e.g. Kumar et al. 1995; Noiri et al. 2005). Phosphate is not well-preserved in the sedimentary record, but its behaviour is tracked well by $\mathrm{Cd}$, which substitutes into calcite (Henderson 2002). $\mathrm{Cd} / \mathrm{Ca}$ ratio in foraminifera allows reconstruction of phosphate utilization (e.g. Rickaby \& Elderfield 1999). A recent new proxy for phosphate utilization is $\mathrm{Cd} / \mathrm{P}$ ratio in phytoplankton particulate matter (Elderfield \& Rickaby 2000; Cullen \& Sherrell 2005). Nitrate utilization can be tracked by $\delta^{15} \mathrm{~N}$, which increases in organic matter with increasing nitrogen uptake (Sigman et al. 1997; Robinson et al. 2005). This proxy has been demonstrated also to work for the Mesozoic (Jenkyns et al. 2001). For silicate, biogenic opal (e.g. diatom skeletons) preferentially incorporates the light isotope of silicon, ${ }^{28} \mathrm{Si}$, resulting in increasingly positive $\delta^{30} \mathrm{Si}$ values with increasing silicic acid utilization (De La Rocha et al. 1998; Reynolds et al. 2006). Rare earth element distribution coefficients in benthic foraminifera also show promise as nutrient utilization proxies (e.g. Haley et al. 2005)

Carbonate alkalinity/weathering fluxes. Carbonate alkalinity (the average concentration and distribution of carbonate and bicarbonate ions) determines the chemical speciation of carbon in the upper ocean and therefore the amount of $\mathrm{CO}_{2}$ that can be drawn into the surface ocean from the atmosphere (Henderson 2002). Rivers constitute the major delivery system for alkalinity (generally bicarbonate ion) and weathering fluxes (most importantly $\mathrm{Ca}^{2+}$ ) to the oceans (e.g. Raymond \& Cole 2003). Foraminiferal $\mathrm{Ba} / \mathrm{Ca}$ ratios have been used as a proxy for past alkalinity distributions (Lea 1993) although the relationship between the Ba and alkalinity cycles is complex (Rubin et al. 2003). ${ }^{87} \mathrm{Sr} /{ }^{86} \mathrm{Sr}$ in carbonate (e.g. Dessert et al. 2001) and ${ }^{187} \mathrm{Os} /{ }^{186}$ Os ratios in clastic sediments (e.g. Cohen et al. 2004) measure weathering flux from continental sources, but mainly pick up periods of high-rate continental weathering (e.g. Ravizza et al. 2001). From marine sediments, the ${ }^{87} \mathrm{Sr} /{ }^{86} \mathrm{Sr}$ curve is particularly useful 
as a weathering proxy, and, with biostratigraphical context, a powerful estimator of numerical age (Francois \& Walker 1992; McArthur et al. 2001). Ge/Si ratios in diatom silica (opal) also show some promise as continental weathering proxies (e.g. Munhoven \& Francois 1996; Jones et al. 2002), although temperature-dependent effects in the oceans need to be accounted for (e.g. Hammond et al. 2004). Hf and Nd isotope ratio time trajectories in manganese crusts show relative deviations during glacial periods that have been interpreted as a mechanical weathering proxy (van de Flierdt et al. 2002). Overall, good proxies for global oceanic alkalinity and weathering are lacking (Henderson 2002).

$p H$. Oceanic $\mathrm{pH}$ provides insights into how the carbonate chemistry of the oceans, including depth to lysocline, has changed through time (e.g. Sanyal et al. 1995). With increasing oceanic $\mathrm{pH}$, concentration of the chemical species $\mathrm{B}(\mathrm{OH})_{3}$ reduces and $\mathrm{B}(\mathrm{OH})_{4}{ }^{-}$increases (e.g. Vengosh et al. 1991; Zeebe 2005). Isotopic fractionation between these two species results in an up to $\sim 20 \%$ isotopic shift in $\delta^{11} \mathrm{~B}$ which is recorded by foraminiferal carbonate (e.g. Vengosh et al. 1991; Zeebe 2005). This proxy has been applied to other carbonate reservoirs (e.g. Honisch et al. 2004) and has been applied over a long time span, even back to the Silurian (e.g. Joachimski et al. 2005), although reliable estimates only extend back to the Palaeocene (Pearson \& Palmer 2000). However, several parameters of the boron/borate/boric acid system need to be better known before long-term estimates can be used with confidence (e.g. Pagani et al. 2005a). Palaeo-pH over Phanerozoic timescales has also been estimated by Royer et al. (2004) based on the calcium-ion concentration of seawater and modelled atmospheric $\mathrm{CO}_{2}$ concentrations.

Atmospheric $\mathrm{CO}_{2}$. Atmospheric $\mathrm{CO}_{2}$ concentrations that pre-date the $\sim 800 \mathrm{ky}$ direct record provided by ice cores (e.g. Siegenthaler et al. 2005) are of extreme importance for palaeoenvironmental reconstruction. Of oceanic proxies, $\delta^{13} \mathrm{C}$ of organic materials has been 
particularly successful, and has recently been refined with studies that focus on $\delta^{13} \mathrm{C}$ derived from a single group of organisms, for example, alkenones (e.g. Pagani 2002), rather than total marine organic material (Henderson 2002). The alkenones record extends back to the Eocene-Oligocene boundary (e.g. Pagani et al. 2005b). Atmospheric $\mathrm{CO}_{2}$ from $\delta^{13} \mathrm{C}$ of other organic materials, including terrestrial materials such as fossil wood (Hesselbo et al. 2000) has been demonstrated back to the Jurassic. $\delta^{13} \mathrm{C}$ of carbonate, including both marine (Buggisch 1991), freshwater (Yemane \& Kelts 1996) and pedogenic (Royer et al. 2001), has also been used as a proxy for atmospheric and oceanic carbon source and for rates of carbon burial (e.g. Schouten et al. 2000; Strauss \& Peters-Kottig 2003). Oceanic pH has also been used as a proxy for atmospheric $\mathrm{CO}_{2}$ concentration, although this requires assumptions to be made about past dissolved inorganic carbon, $\mathrm{Ca}$ flux to the oceans and alkalinity (Henderson 2002; Pearson \& Palmer 2002). By this method, Pearson \& Palmer (2000) and Demicco et al. (2003) have reconstructed atmospheric $\mathrm{CO}_{2}$ concentration back to 60 m.y. ago. Recently, the technique has been demonstrated for Neoproterozoic carbonates (Kasemann et al. 2005).

\section{Lithological proxies.}

Sedimentary rocks are the most venerable palaeoclimate proxies in terms of when they were first used (e.g. Lyell 1830; Croll 1867) and they offer palaeoclimatic information from some of the earliest periods of Earth history (e.g. Moore et al. 2001). Köppen \& Wegener (1924) made the earliest attempt at quantitative use of sedimentary facies for palaeoclimate reconstruction. The 1960's saw a period of critical appraisal of the value of sedimentary facies as palaeoclimate indicators (e.g. Nairn 1961; Van Houten 1961; Smith 1963). Since the early 1970 's, the focus has been increasingly on chemical or isotopic components of the facies rather than interpretation of the facies themselves, most particularly for carbonate sediments, although they continue to be important because of the time range over which they 
are useful. Sellwood et al. (1993) reviewed the sedimentary facies that are key palaeoclimatic indicators.

Carbonate rocks. Marine carbonate facies are some of the most important palaeoclimate indicators. Sellwood et al. (1993) distinguished between temperature-related facies changes, i.e. related to cool or warm water, and carbonate structures, such as reefs. Modern-day warm-water shelves carbonates form between $30^{\circ} \mathrm{S}$ and $30^{\circ} \mathrm{N}$ and include reef-building corals, codiacian algae, and ooids, aggregates and pellets. Temperate water carbonates, which extended as far as $50^{\circ} \mathrm{N}$ during the Cretaceous, are characterized by benthic foraminiferans, molluscs, bryozoans, barnacles and calcareous red algae, along with ahermatypic (non-reef-forming) corals. The latitudinal distribution of shelf carbonates has varied through the Phanerozoic, although total area appears to have been relatively invariant (Kiessling et al. 2003). Reefs and carbonate build-ups are interpreted as indicating the presence of former warm seaways (Sellwood et al. 1993), although the communities of organisms responsible have varied through the Phanerozoic (e.g. Braga \& Aguirre 2001; Edinger et al. 2002; Leinfelder et al. 2005). Sellwood et al. (1993) gave the poleward limit of reefs as greater than $30^{\circ}$ away from the equator. In the interim, it has been recognised that deep-water, cold-temperate reefs can form at latitudes of up to $65^{\circ} \mathrm{N}$ (e.g. Freiwald et al. 1997; Freiwald \& Wilson 1998).

Evaporites. Evaporites are the second major facies treated by Sellwood et al. (1993) who defined them as forming anywhere on the Earth's surface where evaporation exceeds precipitation and/or rate of water inflow. Ziegler (2003) added that this must occur under the descending limbs of Hadley cells, today centred between $10^{\circ}$ and $40^{\circ}$ north or south. However, it is worth noting that hypersaline brines form in Antarctic dry valleys today 
(Doran et al. 2003), at high latitudes and very low temperatures. The earliest evaporites are Archaean in age (e.g. Zharkov 2005).

Storm deposits. Storm deposits are another important palaeoclimatic indicator with high preservation potential (Sellwood et al. 1993). Tempestites (e.g. Myrow \& Southard 1996; Mohseni \& Al-Aasm 2004), other storm deposits (e.g. Hentschke \& Milkert 1996; Chaudhuri 2005), and windblown dust (e.g. Dodonov \& Baiguzina 1995; Clemens 1998; Qin et al. 2005) can indicate changing storminess, and, with modelling, even show the geographical distribution of storm belts through time (Agustsdottir et al. 1999). Palaeowind directions are also derivable in some cases (e.g. Allen 1996; Pochat et al. 2005).

Glacial sediments. Glacial sediments are archetypal indicators of cold palaeoclimates (Agassiz 1828; Darwin 1842). The direct products of glaciation, deposited in the immediate glacial environment, are generally unsorted diamictons (or, when lithified, diamictite), consisting of rounded granule to large boulder clasts, matrix supported in clay-silt. These are often referred to as boulder clay or till/tillite (Sellwood et al. 1993) and are in many cases intercalated with clast-supported conglomerate lenses. In the older record tillites/glacial diamictites need careful interpretation to avoid confusion with diamictites resulting from meteorite impact (e.g. Mory et al. 2000), subaerial debris flows (e.g. Blair 1999), or nonglacially derived sub-aqueous gravity flows (e.g. Eyles 1993), but reliable records extend back to the Archaean (e.g. Young et al. 1998). Fluvial systems driven by glacial meltwater produce outwash facies (e.g. Visser 1997; O'Brien et al. 1998), which can feed into glaciomarine systems including submarine fans. Glaciers feeding directly into the sea, with or without intervening ice shelves also produce distinctive glaciomarine deposits, commonly with dropstones from floating ice or icebergs (e.g. Bennett \& Doyle 1996; Visser 1997; Price 
1999). More distally, marine sequences can preserve layers of ice-rafted debris, shed from more far-travelled floating ice (e.g. Keany et al. 1976; Isbell et al. 2001). For periglacial environments, evidence pre-Late Cenozoic is sparse, but there are records from the Neoproterozoic (Williams 1998), and Mesozoic (Constantine et al. 1998).

Glendonites. The questions raised by Sellwood et al. (1993) over the palaeoclimatic significance of glendonite carbonate nodules have largely been resolved and their status as indicators of cold subaqueous environments confirmed (e.g. Swainson \& Hammond 2001). Glendonite carbonate nodules are distinctive pseudomorphs after ikaite, a low-temperature, hydrous form of calcite that may be associated with methane hydrates (Greinert \& Derkachev 2004). The precursor ikaite forms under near-freezing conditions at moderately elevated hydrostatic pressure (Swainson \& Hammond 2001). Glendonites are characteristic of glaciomarine sediments throughout the Neoproterozoic and Phanerozoic (e.g. Price 1999; McLachlan et al. 2001; Alley \& Frakes 2003; James et al. 2005). 
Sub-glacial volcanic deposits. The deposits of sub-glacial volcanic eruptions, which include lavas overlying or intercalated with glacial diamicton, and intercalated or laterally associated with hyaloclastite breccia deltas (e.g. Smellie et al. 2006) indicate the presence of former ice caps and ice sheets (Smellie 2000). These have been described from Antarctica (e.g. Smellie \& Skilling 1994; Smellie et al. 2006) and Iceland (e.g. Schopka et al. 2006). They constitute a new quantitative proxy for the presence or absence of ice caps (e.g. Schopka et al. 2006) and palaeo ice sheet thickness (e.g. Smellie et al. 2006), complementing nunatak and trimline studies (e.g. Rae et al. 2004; Paus et al. 2006). Zeolite compositions from subglacially erupted lavas can also be used to distinguish between marine and freshwater/glacial eruptive environments (Johnson \& Smellie in press).

Coal, lignite and peat. Coal, lignite and peat deposits are well-recognised indicators of terrestrial humidity (Sellwood et al. 1993), i.e. areas where precipitation exceeds evaporation (e.g. Parrish et al. 1982; Hallam 1985). A combination of tectonic (e.g. McCabe 1991), biological (e.g. McCabe \& Shanley 1992), eustatic (e.g. Staub 2002) and climatic (e.g. McCabe \& Parrish 1992) factors is required for the preservation of coal- or lignite-forming mires. There are two main types (Moore 1995): rain-fed mires, which form in humid maritime climates at high-mid latitudes today; and flow-fed mires, which currently form at low latitudes. The latitudes of coal formation may, however, have been different in the past (Crowley \& North 1991), although, for the Palaeozoic, for example, both low latitude flowfed mires (e.g. Edwards 1998) and high latitude, rain- and flow-fed mires (e.g. Michaelsen \& Henderson 2000) have been recognised.

Fusain. Wildfires (Harris 1981; Sellwood et al. 1993; Glasspool 2000) are represented in the geological record by the presence of fossil charcoal, predominantly fusain (Scott 1989; Scott 
et al. 2000), in sedimentary rocks, and are indicators of a rapid growing season punctuated by periods of drought (Finkelstein et al. 2005) terminated with thunderstorms (Edwards 1984). The lack of a more complete treatment of fire through the Phanerozoic, as highlighted by Sellwood et al. (1993), has since been addressed by the excellent review by Scott (2000). Late Carboniferous wildfires in tropical lowland peats (Scott 2000) may reflect elevated levels of atmospheric $\mathrm{O}_{2}$ at that time (Berner et al. 2003).

Palaeosols. Palaeosols provide important palaeoclimatic information, in particular palaeoprecipitation (e.g. Sellwood et al. 1993; Retallack 2001). Palaeosols represent intervals or areas of low or no sedimentation. Their mineral and chemical composition reflects the interaction between their source terrigenous clastic sediments and the processes of weathering, which can be physical, chemical and biological. Sellwood et al. (1993) identified five different, major, climatically significant palaeosol types. Laterites and bauxites they linked with humid tropical climate with a long dry season. They distinguished between pedogenic and groundwater laterites, the latter of which occur in low land and coastal settings, deriving their iron from groundwater. Sellwood et al. (1993) pointed out that although most bauxites occur with laterites, some may form in depressions in karst. Price et al. (1997a) modelled the occurrence of bauxites and showed that they require mean annual temperatures greater than $22 \mathrm{C}^{\circ}$ or $23 \mathrm{C}^{\circ}$ and high precipitation for at least 6 months of the year. Clay-rich vertisols, with characteristic internal features and micro structures, were linked by Sellwood et al. (1993) with exclusively warm temperate to tropical climates with four to eight dry months each year, in some cases associated with playas in otherwise arid or semi-arid regions. However, recent data suggests that they can also form in humid climates (e.g. Nordt et al. 2004). Chemical analyses of vertisol profiles provide palaeoprecipitation proxies (e.g. Stiles et al. 2001; Driese et al. 2005). 
Calcretes and dolocretes, calcium or magnesium carbonate-rich soils respectively, are also a marker for arid or semi-arid areas, both cold (e.g. Lauriol \& Clark 1999; Rowe \& Maher 2000) and warm (e.g. Jimenez-Espinosa \& Jimenez-Millan 2003), and are often found in association with zones of gypsum precipitation (gypcretes). Alonso-Zarza (2003) has pointed out that there is a continuum between calcretes and palustrine (swamp or marsh) carbonates, and that the latter can form rapidly and under much more humid conditions than calcretes, requiring care when making palaeoenvironmental interpretations. This is particularly important when determing palaeoprecipitation via transfer functions derived from the depth to the nodular, pedogenic carbonate horizon (Retallack 2005).

Cementation of soil, or the underlying saprolite, by secondary silica forms silcretes (e.g. Webb \& Golding 1998). Since the work by Sellwood et al. (1993) silcretes have been identified forming today in central Australia. Although Webb \& Golding (1998) suggested an association with long-term aridity and seasonally high evaporation, allowing silica to precipitate from highly saline ground waters, they argue that silcretes still have no clear climatic association. Recent work by Ullyott \& Nash (2006) and Alexandre et al. (2004) suggested that silcretes may also form in cool and wet climates.

The final category of palaeosol identified by Sellwood et al. (1993) are podzols (spodosols of Mack et al. (1993)). These form in cool wet environments where humus accumulates, promoting acidic conditions (e.g. Bonifacio et al. 2006). Sellwood et al. (1993) pointed out, however, that podzols may form under warmer climatic regimes in well-drained siliceous substrates (e.g. Van Niekerk et al. 1999). 
Mack \& James (1994) proposed a simpler scheme using the classification scheme of Mack et al. (1993), and based on a theoretical model of four palaeoclimatic palaeosol associations. They defined: 1) a wet equatorial zone, characterized by oxisols (laterites and bauxites), with secondary clay-rich argillisols and humic histosols (including coal); 2) a subtropical dry zone containing calcisols (calcretes and dolocretes) with subsidiary gypsisols (gypcretes) and vertisols; 3) a moist mid-latitude zone with argillisols, spodosols (rich in organic matter and iron/aluminium oxides; common in coniferous forests today and equivalent to podzols), gleysols (waterlogged soils) and histosols; and 4) a polar zone with gleysols and protosols (regolithic soils).

Clay mineralogy. Of parallel importance to soils, the distribution in oceanic sediments of clay minerals will reflect weathering processes and soil development in adjacent continents, providing an indirect record of terrestrial climate (e.g. Chamley 1989; Sellwood et al. 1993; Chamley 1998; Thiry 2000). A recent review by Thiry (2000) highlights the difficulties in extracting a climate signal, in particular the time lag introduced by the time it takes for soils to form, and biases in the signal that result from, for example, the longevity of kaolinite deposits (indicative of tropical wet climates). Differential settling of clay particles between proximal and distal settings may also introduce a bias in the signal (e.g. Simkevicius et al. 2003). Nevertheless, for example, the declining proportions of crystallized smectite and chlorite, and increasing illite in marine sediments have been used to trace the transition from humid to subpolar and polar conditions in the high southern latitudes (e.g. Ehrmann et al. 2005), and characteristic proportions of kaolinite, smectite, chlorite and illlite indicate warm equable Late Triassic and humid Early Jurassic climates at mid-northern latitudes (Ahlberg et al. 2003). In terrestrial settings, Ballantyne (1994) suggested that low gibbsite concentration 
of soils in formerly glaciated is a proxy for glacial erosion, which has recently been confirmed by cosmogenic isotope dating (Ballantyne et al. 2006).

Sortable silt. This is a relatively new proxy for palaeocurrent speed and rates of deep-water flow (e.g. McCave et al. 1995). It uses the 10-63 $\mu \mathrm{m}$ fraction of marine sediment because this fraction is most sensitive to sorting in response to hydrodynamic processes and its properties can be used to infer current speed (McCave et al. 1995). The proxy works well for the Cenozoic (e.g. Pfuhl \& McCave 2005), where contourite drifts have been identified from sea-floor topography and geographic association, but should, in theory be applicable to the entire interrogateable sea-floor record.

Aeolianites. The final class of palaeoclimate indicator facies treated by Sellwood et al. (1993) was aeolianites (wind-blown sediments). As Sellwood et al. (1993) pointed out, the simple association between these deposits and hot arid climates has been seriously questioned and their main palaeoclimatic significance is as palaeowind indicators (e.g. Allen 1993; Adams 2003; Segalen et al. 2004; Le Guern \& Davaud 2005). Fine-grained aeolianites, such as loess deposits and dust (for review see Kohfeld \& Harrison 2001) are important in that they provide the only proxy for atmosphere palaeocirculation (e.g. Henderson 2002). Palaeocirculation information can be derived from interpretation of temporal variations in source region from the chemical and mineralogical composition of dust (e.g. Nakai et al. 1993). In addition to providing palaeowind and palaeocirculation data (e.g. Sun et al. 2004), loess deposits also indicate cold, arid periglacial climates (Lagroix \& Banerjee 2002; Sun \& An 2005).

Palaeontological proxies. 
The empirical use of fossils and fossil assemblages as palaeoclimate indicators can be traced back at least as far as Lyell (1830) and their value was even recognised in classical times (Imbrie \& Newell 1964). Quantifying former climates using biological data is based on three key assumptions (Woodcock 1992): 1) that climatic factors limit the occurrences or associations of taxa; 2) that taxa have characteristics (such as leaf shape, or stomatal density) that respond to climate; and 3) that climate causes variance in relative frequency of taxa. It is useful to subdivide studies that use biological data into taxonomic and morphological types (Wing \& Greenwood 1993) based on whether or not they address assumption "2" above. Quantitative, proxy-based palaeoclimate reconstruction based on fossil data began for terrestrial environments in the 1950's, based on pollen analysis (Faegri \& Iverson 1950), and for the marine environment in the early 1970's with the development of micropalaeontologybased transfer functions by Imbrie \& Kipp (1971). Quantitative techniques relate biological parameters to changes in environment variables such as temperature, $\mathrm{pH}$ or salinity. These parameters can either be measured of individuals (morphological techniques), or of a faunal assemblage (taxonomic techniques).

Taxonomic methods. For the terrestrial realm the primary taxonomic methods for palaeoclimate reconstruction use assemblages of pollen (e.g. Birks 1981) or other palynomorphs (e.g. Stanley 1970; Loboziak et al. 1989). Pollen analysis, using climatic amplitude (e.g. Jimenez-Moreno et al. 2005) and mutual climatic range (e.g. Klotz et al. 2006) techniques, provides data on palaeotemperature and palaeoprecipitation (e.g. Fauquette \& Bertini 2003) as far back as the Eocene (e.g. Harrington 2004). Taxonomic methods based on plant macrofossils (e.g. Baghai \& Jorstad 1995), vertebrates (Markwick 1998; Friedman et al. 2003), molluscs (e.g. Moine \& Rousseau 2002) and arthropods (e.g. Pilny et al. 1987; Williams \& Eyles 1995) provide palaeotemperature data, and have been demonstrated for the 
Cretaceous. Taxon analysis of chironomid midges provides lake palaeosalinity data back to the Late Pleistocene (e.g. Walker 1991) and insect assemblages have been proposed as a marker for low salinity for the Early Cretaceous (Coram \& Jarzembowski 2002). More sophisticated palaeoclimatic treatments of terrestrial faunal assemblages use herbivorous mammals and their feeding habits. These include ecological diversity spectra (e.g. Andrews et al. 1979; Fernandez \& Pelaez-Campomanes 2005), which quantify a range of parameters including temperature, humidity/aridity and annual precipitation potentially back to the Miocene, and cenograms (e.g. Legendre 1986; Rodriguez 1999; Legendre et al. 2005), which provide information on temperature and humidity/aridity back to the Eocene. The nearest living relative method (e.g. MacGinitie 1941), which blurs the boundary between taxonomic and morphological techniques, makes palaeoclimatic inferences based on fossil groups and assemblages by using the ranges and climatic responses of their modern descendants or sister groups (Wing \& Greenwood 1993), and is particularly good for the Cenozoic. The nearest living relative method provides palaeotemperature data from both plants (Poole et al. 2005; Wang et al. 2005), back to the Jurassic, and animals (e.g. Hutchison 1982; Moe \& Smith 2005), back to the Palaeocene.

For the oceanic realm, taxonomic methods of deriving palaeoclimate parameters, such as temperature and salinity, are most commonly derived via transfer functions, which were first developed by Imbrie \& Kipp (1971). These can be calculated from marine (e.g. Sejrup et al. 2004) and lacustrine (e.g. Hausmann \& Kienast 2006) microfossil assemblages, and are commonly applied to Pliocene or younger assemblages (e.g. Andersson 1997), although for palaeoproductivity they extend back to the Palaeocene (Siesser 1995). Transfer functions have evolved since the principal components regression work of Imbrie \& Kipp (1971) and now include weighted averaging and weighted averaging least squares methods (Sejrup et al. 
2004; Hausmann \& Kienast 2006), as well as artificial neural networks (Malmgren \& Nordlund 1997; Peyron \& De Vernal 2001) and maximum likelihood and Bayesian techniques (e.g. Robertson et al. 1999). The applications of transfer function techniques have broadened away from the planktic foraminifera and radiolaria of Imbrie \& Kipp (1971). They now include, in the oceans, benthic foraminifera (e.g. Sejrup et al. 2004), diatoms (e.g. Zielinski et al. 1998), ostracods (e.g. Brouwers et al. 1991), dinoflagellates (e.g. Peyron \& De Vernal 2001), and in lakes, chironomid midges (e.g. Korhola et al. 2001) and diatoms (e.g. Roberts \& McMinn 1999). Parameters estimated include, oceanic palaeoproductivity (e.g. Siesser 1995), ocean bottom water palaeotemperatures (e.g. Brouwers et al. 1991), palaeosalinity (e.g. Sejrup et al. 2004), sea-surface palaeotemperatures (e.g. Andersson 1997; Malmgren \& Nordlund 1997; Zielinski et al. 1998), and seasonal extent of former sea-ice cover (e.g. Peyron \& De Vernal 2001). In lakes, palaeonutrient utilization (e.g. Hausmann \& Kienast 2006), surface palaeotemperature (Korhola et al. 2001) and palaeosalinity (Roberts \& McMinn 1999) have been estimated. Non-transfer-function-based techniques on diatoms have used faunal assemblages (Gersonde \& Zielinski 2000) and modern analogue techniques (Crosta et al. 1998) as proxies for sea-ice extent back to the Pleistocene. Similarity maximum modern-analogue techniques on foraminiferal assemblages from core tops have been also been used as a proxy for sea-ice extent (Sarnthein et al. 2003), again back to the Late Pleistocene. For the older, pre-Cenozoic, record, other non-transfer-function-based methods use faunal assemblages of marine molluscan macrofossils to estimate palaeotemperature (e.g. Kafanov \& Volvenko 1997) and palynomorphs, such as acritarchs, for palaeoproductivity (e.g. Vecoli \& Le Herisse 2004) with applications back to Ordovician times. 
Morphological methods. Morphological methods generally centre around leaf margin analysis, beginning with the work of Bailey \& Sinnott (1916) and culminating in the work of Wolfe (1993) on the climate-leaf analysis multivariate program, or CLAMP. This is widely used as a palaeotemperature proxy (e.g. Gregory-Wodzicki 2000; Kennedy 2003; Spicer et al. 2005) and has been extended back to the Permian (Glasspool et al. 2004). The width of growth rings in fossil wood is also an important morphological technique for palaeotemperature and palaeoprecipitation (e.g. Fritts 1976; Creber \& Chaloner 1985; Francis 1986; Poole et al. 2005). Although results need to be assessed in terms of taxonomic analysis (Brison et al. 2001) the technique has been demonstrated to be effective from Carboniferous times to Recent (e.g. Falcon-Lang 1999; Morgans 1999; Francis \& Poole 2002). Measuring maximum latewood density of tree rings gives the ability to measure hemispheric variations in temperature (Briffa et al. 2004), although this has only been applied to historically recent material. The density of stomata in leaf cuticle has been used as a proxy for palaeo-CO2 concentration (Woodward 1987; Woodward \& Bazzaz 1988). This has been shown to be effective back to the Carboniferous (e.g. Otto-Bliesner \& Upchurch 1997; McElwain et al. 1999; Retallack 2002; Thorn \& DeConto 2006). For the oceans, palaeo-carbonate ion concentration, which determines the water depth at which all calcite has dissolved from the sediment or lysocline (e.g. Ridgwell 2005), has been determined by estimating the degree of dissolution of individual foraminifera of a particular size (e.g. Lohmann 1995). However, the situation is more complicated in glacial periods (Broecker \& Clark 2001) and dissolution effects at the sediment-water interface cannot be discounted (e.g. de Villiers 2005).

\section{Modelling}

Palaeoclimate modelling falls into two main categories: The main, and most significant, category is by the generation and interpretation of climate analogues. These can take the form 
of conceptual models (Parrish 1993), or be carried out using numerical, computer-based global circulation models (GCMs) or Earth models of intermediate complexity (EMICs) (for a recent review see McGuffie \& Henderson-Sellers 2001). These attempt to generate analogues for climate over a range of spatial and temporal scales up to and including the complete globe. The second category is what are called geochemical (Royer et al. 2001), mass-balance (e.g. Beerling 1999), or trend models (e.g. Richards 1998). These use palaeoclimate proxies or model outputs to reconstruct the evolution of a particular atmospheric or oceanic chemical species, such as oxygen or carbon dioxide, over a range of geological time, up to and including the entire geological record.

Climate analogue modelling. It was recognised in the early $19^{\text {th }}$ Century that former global climates differed from today's (Agassiz 1828; Darwin 1842). Following the work of Tyndall (1861) and Arrhenius (1896) a key role for $\mathrm{CO}_{2}$ was suspected from the beginning (Chamberlin 1897, 1899). The first empirical palaeoclimatic reconstructions for the Phanerozoic were carried out by Köppen \& Wegener (1924), who used a simple zonal climate model and the distribution of palaeoclimatic indicator facies such as coal or glacial sediments in a continental drift framework to refine the fit of the continents. These applications of palaeoclimate studies based on simple zonal schemes continued into the 1960 's (e.g. Nairn 1961). It was only with the advent of palaeomagnetism in the 1950's and plate tectonics in the 1960's (summarized in Irving 2005) that continental palaeolatitudes could be independently fixed. This freed the geological record to provide ground truth for increasingly empirical, conceptual (Parrish 1993) and numerical (Schneider \& Dickinson 1974) palaeoclimate models. The earliest numerical models were relatively simple analogues of Late Pleistocene glacial climates (Alyea 1972; Gates 1974). These quickly moved to modelling of palaeoclimates with global circulation models (GCMs) initially of Late 
Pleistocene glacial climates (Gates 1976), and at the end of the decade the CLIMAP project saw the first attempts to provide model boundary conditions and to evaluate climate models with proxy data (CLIMAP 1981). From the 1980's, palaeoclimate modelling was extended first to the Mesozoic (Barron et al. 1981; Kutzbach \& Gallimore 1989; Chandler et al. 1992; Valdes \& Sellwood 1992) and then the Palaeozoic (Crowley \& Baum 1992; Kutzbach \& Ziegler 1993; Otto-Bliesner 1995; Gibbs et al. 1997).

Although the first coupled ocean-atmosphere GCM was realised in the 1960's (Manabe \& Bryan 1969), it was not until the 1990's that these were applied to palaeoclimate studies (Stocker et al. 1992; Cubasch et al. 1997; Schiller et al. 1997) initially for the early Holocene and the last interglacial (Eemian) (Texier et al. 1997; Montoya et al. 1998). Since 2000, these GCMs have been increasingly applied to the older Cenozoic and Mesozoic (OttoBliesner et al. 2002; Haywood \& Valdes 2004; Haywood et al. 2004) (Fig. 3). In the 1990's, multiple or ensemble runs (e.g. Cubasch et al. 1994; Hoar et al. 2004) and asynchronous coupling (e.g. Liu et al. 1999; Dutton \& Barron 2000), where the outputs of one EMIC or GCM is used to force climate parameters in a second EMIC or GCM, were used to model climate behaviour.

Since the late 90's, the emphasis has been on model "validation" or "evaluation" (the second term is preferred because it does not confer any sense of "approval" (Kohfeld \& Harrison 2000)). This uses multi-proxy data sets (e.g. Price et al. 1995; Price et al. 1997b; Sellwood \& Valdes 1997; Sellwood et al. 2000; Felzer \& Thompson 2001; Haywood et al. 2004) to minimize the uncertainties inherent in numerical models (Dickinson 1989). A second trend is that models have become more sophisticated with coupling of ice-sheet (e.g. Ridley et al. 
2005) and biome (e.g. Haywood et al. 2002a; Snyder et al. 2004; Brentnall et al. 2005) models to the coupled atmosphere-ocean GCMs. 
Geochemical or mass-balance modelling. Geochemical or mass balance modelling uses calculations of the transfer of material between the lithosphere, hydrosphere, and atmosphere (Li 1972; Garrels \& Lerman 1984; Lasaga \& Berner 1998), to assess the long term evolution of atmospheric and oceanic composition. It is by necessity generalized and the geographical patchiness and temporal incompleteness of the terrestrial and particularly the pre-Jurassic marine record must qualify its interpretation. Modelling of the long-term carbon cycle is one of the keys to understanding Phanerozoic climate change (e.g. Berner \& Barron 1984; Gifford 1994; Berner 1998; Berner \& Kothavala 2001). Changes in the carbon cycle can be measured directly, with varying degrees of precision, from organic carbon in sedimentary rocks or carbonate in limestone (this latter may take the form of sedimentary rock or carbonate cements in, for example, soils) (e.g. Berner 1998).

Of secondary importance is the long-term oxygen cycle (e.g. Berner \& Canfield 1989; Berner 1999; Berner et al. 2000; Berner 2001). Some authors argue that oxygen concentration changed substantially during the Phanerozoic, possibly peaking in the late Carboniferous (e.g. Berner \& Canfield 1989; Beerling et al. 2002) although there are strong counterarguments that it was relatively unvarying (e.g. Lenton \& Watson 2000). The long-term oxygen cycle is indirectly modelled from the carbon cycle and the sulphur cycle (e.g. Berner 2005) (the sulphur cycle is measured directly from evaporitic rocks and iron pyrites in sedimentary rocks (e.g. Francois \& Gerard 1986; Railsback 1992)).

Three other cycles that are important for understanding atmospheric evolution are the nitrogen cycle (e.g. Falkowski 1997), the phosphorus cycle (Guidry \& Mackenzie 2000; Lenton 2001) and the silicon cycle in the oceans (Ragueneau et al. 2000; Matsumoto et al. 2002). All three are implicated in the drawdown of carbon and its incorporation in marine 
sediments (e.g. Falkowski 1997; Lenton 2001; Matsumoto et al. 2002). One of the most spectacular successes of mass-balance modelling is in providing support for the extreme atmospheric changes associated with the Neoproterozoic 'Snowball Earth' model (Hoffman et al. 1998). Recent mass-balance models are sophisticated, incorporating multiple elements and both major oceanic and atmospheric cycles (e.g. Hansen \& Wallmann 2003; Bergman et al. 2004)

\section{Phanerozoic climate modes}

Frakes et al. (1992) looked at climates back to 600 million years ago and identified what they termed "climate modes" with alternating episodes of cool or warm climates (Table 1; Fig. 1a). They defined "cool modes" as "times of global refrigeration during which ice was present on earth". Their "warm modes" they defined as times "when climates were globally warm, as indicated by the abundance of evaporites, geochemical data, faunal distributions, etc, and with little or no polar ice". Frakes et al. (1992) argued that warm-cool climate mode pairs spanned intervals of approximately 150 million years: about half a galactic year. Superimposed upon these climate modes were brief intervals of contrasting climates (Fig. 1b, Table 1), which they did not consider sufficiently long to merit climate modes of their own. These are important, however, and the geological background to some will be dealt with in slightly more detail in this chapter, as they give insights into the extremes of climate change. All numerical ages quoted for chronostratigraphic units and boundaries are according to Gradstein et al. (2004).

Frakes et al. (1992) proposed eight climate modes for the Phanerozoic (Table 1; Fig. 1a). They grouped these into four warm: Cambrian to Middle Ordovician; middle Silurian to 
Early Carboniferous; latest Permian to early Jurassic; late Cretaceous to early Palaeogene, inclusive; and four cool: late Ordovician to early Silurian; early Carboniferous to late Permian; late Jurassic to early Cretaceous; mid-Palaeogene to Recent, inclusive. These are treated alternately in time-sequential order below.

\section{Climate modes}

Earliest Cambrian to Middle Ordovician warm mode. Frakes et al. (1992) placed the beginning of this warm mode at the end of the latest Neoproterozoic glaciation, which they assumed to be at the Precambrian-Cambrian boundary. Since then, the latest Precambrian, Ediacaran Period has been added (Knoll et al. 2006) post-dating the last Neoproterozoic glacial deposits, this period starting between 635 and 600 million years ago (Knoll et al. 2006). The Ediacaran terminates at the earliest Cambrian, now 540 million years ago (Gradstein et al. 2004), 30 million years later than the dates used by Frakes et al. (1992) from the Decade of North American Geology (DNAG) timescale of Palmer (1983). Ediacaran stratigraphic (Knoll et al. 2006) and stable isotope (Le Guerroue et al. 2006) data suggest that it post-dates major Neoproterozoic glaciation and should be included in the warm mode. Frakes et al. (1992) suggested that this warm mode ended prior to the beginning of the Ordovician Katian stage which is now dated at about 461 million years ago, an interpretation endorsed by Page et al. (in press) in this volume.

This warm mode is marked by substantial deposition of evaporites and moderately high rates of carbonate formation by Phanerozoic standards (Frakes et al. 1992). One notable biogeochemical event during this warm mode is the deposition of substantial phosphorite deposits around the time of the Ediacaran-Cambrian boundary (Cook 1992). This accumulation of phosphorite differs from other Phanerozoic accumulations in that it does not 
appear to be associated with oceanic upwelling and may be related to a change in ocean chemistry associated with a rise in atmospheric oxygen and the formation of the first hard skeletons.

At least three brief intervals of probable cooler climate punctuate this warm mode. A brief glacial episode is recognised in the Ediacaran at about $580 \mathrm{Ma}$ (c1, Fig. 1b) from $\delta^{13} \mathrm{C}$ values in marine carbonates (Le Guerroue et al. 2006). Another short-lived episode of cool, possibly glacial climate is identified in the Steptoan of the Late Cambrian (e.g. Saltzman et al. 2000), at $494 \mathrm{Ma}$ (c2, Fig. 1b), again from a positive excursion of up to $5 \%$ in brachiopod carbonate (Cowan et al. 2005) immediately followed by a major global sea-level drop (Glumac \& Spivak-Bimdorf 2002). Although Frakes et al. (1992) observed that unequivocal Cambrian or Early Ordovician glacial sediments are rare, Early Ordovician, Tremadocian, $480 \mathrm{Ma}$ (c3, Fig. 1b), glacial deposits have been identified in the Meguma Zone of Nova Scotia (Schenk 1995).

Late Ordovician to early Silurian cool mode. Suggestions for the duration of this cool mode have varied since Frakes et al. (1992). From a review of Phanerozoic glacial deposits, Evans (2003) estimated that it lasted of the order of 17 million years, from the latest Ordovician (Hirnantian), 445 Ma until the Llandovery-Wenlock boundary at the end of the Early Silurian, 428 Ma. Royer et al. (2004), using pH-corrected Phanerozoic $\delta^{18} \mathrm{O}$ trends, estimate the duration at less than 10 million years and Brenchley et al. (2003) estimate that widespread ice sheets lasted less than 1 m.y. However, Page et al. (in press) in this volume presents evidence that support the assessment of Frakes et al. (1992) with a beginning at 461 Ma. 
Frakes et al. (1992) documented widespread glacial sediments over a large area of the African and South American parts of Gondwana, and in terranes probably sourced from there. Page et al. (in press) in this volume present sea-level data and lithological evidence from West Africa, Canada and France for two middle Caradoc and one early Ashgill cool or glacial episodes in the Late Ordovician (Katian stage) (c4-c6, Table 1 and Fig. 1b) and there is some evidence in Baltica for cool phases at these times (Kaljo et al. 2003). These do not appear to represent glaciation on the scale of Hirnantian and Early Silurian episodes and may indicate a gradual transition from the preceding warm mode. Data from Baltica restricts full glaciation to the latest Ordovician and Early Silurian (Jeppsson \& Calner 2003; Kaljo et al. 2003; Legrand 2003). Four glacial episodes are recognised (Kaljo et al. 2003), including the latest Ordovician Hirnantian episode, at $\sim 45 \mathrm{Ma}$ (c7, Fig. 1b), and Silurian glacial episodes in the Aeronian, 439 Ma (c8, Fig. 1b), Telychian, 436 Ma (c9, Fig. 1b), and earliest Wenlock (Sheinwoodian), 428 Ma (c10, Fig. 1b)). The Early Silurian is marked by a series of global oceanic changes, termed Primo and Secundo states by Aldridge et al. (1993), inferred to have been determined by whether deeper oceanic circulation is driven by cold, or saline, density currents (e.g. Jeppsson \& Aldridge 2000). Given the relative brevity of this cool mode it is not marked by any notable deviations from cool climate, although Secundo states in the Llandovery to earliest Wenlock interval are marked by warm high latitudes (Aldridge et al. 1993).

Mid Silurian to Early Carboniferous warm mode. The latest clear evidence for Silurian glaciation comes from isotopic and sedimentological evidence in the Early Wenlock (Azmy et al. 1998; Kaljo et al. 2003), placing the start of this warm mode slightly earlier than the end-Wenlock suggested by Frakes et al. (1992). The end of this warm mode is open to interpretation. Frakes et al. (1992) placed it at the Visean-Namurian boundary (the Namurian is now called the Serpukhovian (Gradstein et al. 2004)), 326 m.y. ago according 
to Gradstein et al. (2004). However, Evans (2003) included the high-latitude Late Devonian, Famennian and Early Carboniferous, Tournaisean/Visean glaciations in the following cool mode, which would terminate this warm mode at $\sim 375$ Ma.

Based on the distribution of carbonates, evaporites, and coal deposits, Frakes et al. (1992) argued that this warm mode demonstrated a progressive global warming to Late Devonian times and tentatively placed its end at the beginning of the Serpukhovian. Carbonates show a progressive expansion to higher and higher latitudes during this period. However, within this warm mode, there is evidence for Late Devonian glaciation at the Frasnian-Famennian boundary (Evans 2003), 375 Ma (c11, Fig. 1b), a Gondwana "mini-glaciation" at the Devonian-Carboniferous boundary (Caplan \& Bustin 1999), 360 Ma (c12, Fig. 1b) and glaciation in the Early Carboniferous (Tournaisean-Visean boundary), $345 \mathrm{Ma}$ (c13, Fig. 1b). Frakes et al. (1992) explained these glaciations by the passage of parts of Gondwana over the South Pole, largely confirmed by Evans (2003), i.e., high latitude glaciations not requiring any major perturbation of the Earth System. However, the $\mathrm{pH}$-corrected $\mathrm{CO}_{2}$ and palaeotemperature curve of Royer et al. (2004) suggest that following a palaeotemperature peak at $\sim 380 \mathrm{Ma}$ (early Late Devonian), there is a steady decline into the Carboniferous, with notable steeper drops between around $375 \mathrm{Ma}$ and $360 \mathrm{Ma}$, which coincide with the Famennian (Streel et al. 2000), Devonian-Carboniferous boundary (Caplan \& Bustin 1999) and Early Carboniferous (Evans 2003) glaciations.

Early Carboniferous to late Permian cool mode. Frakes et al. (1992) placed the beginning of this cool mode in the early Serpukhovian, at $~ 325$ Ma. Evidence from South Africa and Australia supports an early glacial phase in this cool mode between 325 and 315 Ma (Evans 2003). The end of this cool mode was estimated by Frakes et al. (1992) to be in the Late 
Permian at what was the Kazanian-Tatarian boundary (now the WuchiapingianChanghsingian) at $\sim 254$ Ma. The most recent data (Eyles et al. 2002; Eyles et al. 2006) place the latest glacially-influenced sedimentation in the latest Early Permian, Kungurian, at 271 Ma.

The latitudinal distribution of glacial sediments summarised by Frakes et al. (1992) suggests that low-latitude glaciation $\left(35-40^{\circ}\right.$ from the equator) during this cool mode occurred in two main phases, the first in the late Serpukhovian to end-Moscovian (previously called late Namurian and Westphalian) and the second in the Asselian and Sakmarian of the earliest Permian (Frakes et al. 1992). Evans (2003) argues that this second phase was at its most intense in a brief period around $297 \mathrm{Ma}$. In the intervening Kasimovian/Gzelian (Stephanian) glacial deposits extended no farther towards the equator than $50^{\circ}$ (Frakes et al. 1992). Interpretation is made more complex because Gondwana was moving rapidly across the high southern latitudes during this cool mode (Frakes et al. 1992). Frakes et al. (1992) argued that post-Sakmarian glaciation was probably restricted to Antarctica, possibly providing a source of dropstone material to Australian and South African sedimentary basins until late in the Early Permian (e.g. Eyles et al. 2002; Evans 2003; Eyles et al. 2006). Carbonates and evaporites are restricted to low-latitudes during this cool mode (Frakes et al. 1992), with evaporites showing a retreat to more equatorial latitudes from the Visean onwards, with carbonates showing a similar change in the mid-Serpukhovian. Both carbonates and evaporites show a recovery from the mid Early Permian onwards (Frakes et al. 1992).

The short-lived climatic amelioration in the Kasimovian/Gzelian (Stephanian) (e.g. Frakes et al. 1992; Bruckschen et al. 1999) merits some discussion. Pennsylvanian cycles of terrestrial to fluvial to submarine sedimentation, called cyclothems and often associated with coal 
formation (e.g. Heckel 1986), which are an expression of glacioeustatic sea-level changes (Veevers \& Powell 1987), are linked to Milankovitch cyclicity, although there is some discussion over what periodicity may be the primary controlling one (e.g. Ross \& Ross 1985; Heckel 1986; Crowley et al. 1993; Algeo et al. 2004; Driese \& Ober 2005). In this scheme, the Kasimovian/Gzelian showed a shortening of duration of the major controlling cycles (Ross \& Ross 1985). However, with a reduction in duration of the Pennsylvanian from 34 to 19 million years (Klein 1990; Gradstein et al. 2004), this simple explanation for Kasimovian/Gzelian warming, and a link to Milankovitch-paced cyclicity, was called into question. An examination of $\delta^{18} \mathrm{O}$ records from Carboniferous brachiopods in western Europe and the former USSR (Bruckschen et al. 1999), coupled with the ${ }^{87} \mathrm{Sr} /{ }^{86} \mathrm{Sr}$ and $\delta^{13} \mathrm{C}$ record shows drops in $\delta^{18} \mathrm{O}$ and ${ }^{87} \mathrm{Sr} /{ }^{86} \mathrm{Sr}$ during the Kasimovian/Gzelian consistent with global warming and suggests that this was quite short-lived and restricted to the Kasimovian at $\sim 307 \mathrm{Ma}$ (w1, Fig. 1b).

Latest Permian to early Jurassic warm mode. Based on the evidence for the latest ice-rafting in Australian basins (Eyles et al. 2002; Eyles et al. 2006) the start of this warm mode fits best at the beginning of the Roadian at $\sim 271 \mathrm{Ma}$, which is slightly earlier than the endWuchiapingian (Kazanian), 254 Ma, proposed by Frakes et al. (1992). Frakes et al. (1992) suggested that this warm mode ended with the first evidence for ice-rafted debris in Jurassic sediments. These are recorded in the Middle Jurassic of northern Asia, at the AalenianBajocian boundary (Chumakov \& Frakes 1997), now dated at 172 Ma (Fig. 1b), although Price (1999) summarised evidence for possible glendonites in the Early Jurassic in Pliensbachian times at $\sim 190$ Ma.

This warm mode is singular in that it contains the extinctions just before and at the PermianTriassic boundary, the latter of which is the most severe in the Phanerozoic (e.g. Knoll et al. 
1996; Hallam \& Wignall 1999). These major changes in the biosphere have implications for lithology-based interpretation of early Triassic climates, for example, the "coal gap" (Retallack et al. 1996), when no coals formed anywhere on the globe even in appropriate sedimentary settings, and interpretations based on palaeosol formation, i.e. spodosols were absent (Retallack 1997). Based on relatively low-precision $\delta^{18} \mathrm{O}$ data and a restricted set of lithological indicators (including palaeosols and reef limestones), Frakes et al. (1992) argued that this warm mode demonstrated an early rapid rise in temperatures in the latest Permian and Early Triassic, followed by a slow cooling trend through the Triassic and Early Jurassic. The more recent, $\mathrm{pH}$-calibrated $\delta^{18} \mathrm{O}$-based palaeotemperature curve of Royer et al. (2004) indicates a very similar overall pattern, with a sharp rise in temperatures from late Early Permian times. Palaeotemperatures reached a peak in the early Middle Triassic, at $245 \mathrm{Ma}$, followed by a slow decline towards the Mid Jurassic, only interrupted by a short-lived rise around the Pliensbachian-Toarcian boundary, at $\sim 183$ Ma (Hesselbo et al. 2000; Royer et al. 2004).

Cooler contrasting climates punctuated this warm mode, with, in some cases, combined evidence for glaciation from isotope excursions and rapid sea level changes. The earliest documented probable glacial event in this warm mode occurred across the GuadalupianLopingian boundary in the Late Permian (Isozaki et al. 2006), at 260 Ma (c14 Fig. 1b). Although the Triassic appears to be devoid of cool intervals, stable isotope studies by Korte et al. (2005) indicated that short-lived, high-amplitude $\delta^{13} \mathrm{O}$ excursions occurred in the Early Triassic, at $\sim 250 \mathrm{Ma}$ (c15, Fig. 1b), and a positive $\delta^{18} \mathrm{O}$ excursion occurred at the CarnianNorian boundary, at $\sim 217$ Ma (c16, Fig. 1b). In the Early Jurassic, rapid sea-level changes provide evidence of short-lived glaciation in the Late Sinemurian, $192 \mathrm{Ma}$ (c17, Fig. 1b), at the Sinemurian-Pliensbachian boundary, $\sim 190$ Ma (c18, Fig. 1b), in the late Pliensbachian, 
$\sim 184 \mathrm{Ma}$ (c19, Fig. 1b), and at the end Toarcian, 176 Ma (c21, Fig. 1b), (e.g. Price 1999; Immenhauser 2005). This Early Jurassic interval is also marked by rapid temperature rise around the Pliensbachian-Toarcian boundary, 183 Ma, (e.g. Pálfy \& Smith 2000; Bailey et al. 2003), which appears to have been followed by a brief early Toarcian cool or possibly glacial episode, notionally at $\sim 182$ Ma (c20, Fig. 1b) (Morard et al. 2003; Wignall et al. 2005). The steep temperature rise deviates from the long-term cooling trend demonstrated by Royer et al. (2004). Belemnite $\mathrm{Mg} / \mathrm{Ca}, \mathrm{Sr} / \mathrm{Ca}$, and $\mathrm{Na} / \mathrm{Ca}$ ratios increase by a factor of between 1.7 and 2, coincident with a $3 \%$ negative shift in $\delta^{18} \mathrm{O}$ and indicating an abrupt warming in northwest Europe of $6-7^{\circ} \mathrm{C}$ and a more active hydrological cycle in this interval (Bailey et al. 2003).

Late Jurassic to Early Cretaceous cool mode. According to Frakes et al. (1992), the start of this cool mode is relatively clearly marked by the appearance of dropstones in high-latitude Mid Jurassic marine deposits from the Aalenian-Bajocian boundary (e.g. Chumakov \& Frakes 1997), at $\sim 172 \mathrm{Ma}$ (c22, Fig. 1b). However, more recent evidence could place the beginning as early as the Pliensbachian (e.g. Price 1999; Immenhauser 2005). Compared with the evidence for its initiation, the termination of this cool mode is more difficult to define. Frakes et al. (1992) used the latest appearance of ice-rafted debris in Australian marine sequences of the Eromanga basin in the early Albian of the Late Cretaceous, which would approximately place it at $\sim 110$ Ma (Fig. 1b). However, a continuation of short-lived glacial episodes from the Mid Jurassic through the Late Cretaceous is supported by the $\mathrm{pH}$ calibrated $\delta^{18} \mathrm{O}$-based palaeotemperature curve of Royer et al. (2004), who argue that the "Late Jurassic to Early Cretaceous" cool mode is fundamentally different from the "Early Carboniferous to late Permian" and "Mid-Palaeogene to Recent" cool modes and is more akin to the "Late Ordovician to early Silurian" one. 
Frakes et al. (1992) argued that this mode was cooler than the preceding and following ones, based on the evidence for seasonal ice at high latitudes in both hemispheres, although not as cold as Palaeozoic cool modes. Based on a variety of indicators, including evidence of ice, palaeobotanical data, oxygen isotopes, clay minerals and the distribution of coals, evaporites and carbonates, they suggested that the intensity of cool climates varied through the mode. Frakes et al. (1992) proposed a cool Mid Jurassic, with seasonal ice in the Bajocian and Bathonian, 167 Ma (c23, Fig. 1b), a conclusion supported by Price (1999). Frakes et al. (1992) suggested warming during the end-Mid Jurassic Callovian, although new oxygen isotope data from shark-tooth enamel and ammonite migration data suggest that the end-Mid Jurassic (late Callovian) was actually a time of glaciation, lasting 2.6 million years (Dromart et al. 2003), 164-161 Ma (c24, Fig. 1b). Glaciation at this time is also suggested by the pHcalibrated $\delta^{18} \mathrm{O}$-based palaeotemperature curve of Royer et al. (2004). For the Oxfordian, Kimmeridgian and Tithonian of the Late Jurassic, Frakes et al. (1992) suggested the warmest climates of the mode, although Price (1999) gave evidence for cold or sub-freezing polar climates in the Tithonian, at $\sim 150 \mathrm{Ma}$ (c25, Fig. 1b). The suggestion of a cooler and more humid earliest Cretaceous (Valanginian and Hauterivian) (Frakes et al. 1992) is consistent with the evidence for cool Valanginian climates, $\sim 140$ Ma (c26 Fig. 1b), presented by Price (1999). Frakes et al. (1992) proposed a gradual warming trend in the later Early Cretaceous following further evidence for ice in the late Early Aptian, $120 \mathrm{Ma}$ (c27, Fig. 1b), (e.g. Price 1999) towards a peak in temperatures in the Albian at the beginning of the following warm mode.

Given the variation in climates during this cool mode it is particularly difficult to pick out climates that deviate significantly from any chosen trend. However, the Late Callovian 
cooling identified by Dromart et al. (2003) is particularly sharp $\left(1-3{ }^{\circ} \mathrm{C}\right.$ for lower to middle latitudes) and associated with increased drawdown of organic carbon and an abrupt fall in global sea levels.

Late Cretaceous to early Palaeogene warm mode. Frakes et al. (1992) place the beginning of this warm mode at the start of the Late Cretaceous in the mid-Albian at $\sim 105 \mathrm{Ma}$. The end of this warm mode is defined by the onset of global cooling as documented in the $\delta^{18} \mathrm{O}$ record of marine foraminifera from about $\sim 55$ Ma onwards (Frakes et al. 1992), which is the Palaeocene-Eocene boundary.

The status of this warm mode has been seriously questioned by Royer et al. (2004). Like the preceding cool mode, this warm mode shows an oscillating climate with shorter cool and warm periods, although the warm periods are substantially warmer than are those in the preceding cool mode. The mode is punctuated by a series of glacial episodes, with evidence of these from sea-level records (e.g. Miller et al. 2005), oxygen isotopes (e.g. Miller et al. 2003) and strontium (e.g. Stoll \& Schrag 1996). Eustatic sea-level data (e.g. Immenhauser 2005), from the Russian and Arabian platforms, show sharp short-lived falls in the late Early and Late Albian, at $\sim 110$ and $\sim 105 \mathrm{Ma}$ (c28, c29, Fig. 1b), which may indicate high-latitude ice caps at that time. Similarly, eustatic sea-level data from offshore New Jersey, combined with the dates of positive excursions in the marine foraminiferal $\delta^{18} \mathrm{O}$ record (e.g. Miller et al. 2005 ) indicates short-lived Antarctic ice-caps of the order of $40-50 \%$ Neogene volumes. The best evidence for these (e.g. Miller et al. 2005) is in the mid-Cenomanian, $96 \mathrm{Ma}$ (c30, Fig. 1b), mid-Turonian, 93-92 Ma (c31, Fig. 1b), and at the Campanian Maastrichtian boundary, $70.6 \mathrm{Ma}(\mathrm{c} 32$, Fig. 1b). 
The temporal distribution of warm and cool or glacial episodes during this warm mode has changed substantially since the synthesis by Frakes et al. (1992). Frakes et al. (1992) suggested that the Albian was one of the warmest periods of this warm mode, along with the Coniacian and Campanian. New data suggests that the warmest period of this warm mode, and one of the warmest periods of the Phanerozoic, was during the Turonian (Wilson et al. 2002; Bice et al. 2006), and that the Albian was possibly quite cool with at least two shortlived high latitude glaciations (e.g. Immenhauser 2005). Additionally, the Turonian episode of maximum warmth is bracketed by short-lived glacial periods in the Cenomanian and Coniacian according to Royer et al. (2004), and punctuated by a glacial episode according to Miller et al. (2005).

Carbon dioxide levels modelled to generate sea-surface temperatures based on foraminiferal $\delta^{18} \mathrm{O}$ and $\mathrm{Mg} / \mathrm{Ca}$ data suggest variation by a factor of four (600-2400 ppmv) in the Albian to Turonian interval (Bice \& Norris 2002; Bice et al. 2006). Benthic foraminifera assemblage data from Venezuela suggest that the following Santonian interval was warm, with some cooling towards the Campanian boundary (Rey et al. 2004). Frakes et al. (1992) suggested that the Campanian was also warm and this is supported by more recent calcareous nannofossil transfer function data from the Indian Ocean (Lees 2002).

As suggested by Frakes et al. (1992), the Maastrichtian was a time of cooler climate. Cooling began at the Campanian-Maastrichtian boundary. $~ 71 \mathrm{Ma}$, with evidence of cooler ocean temperatures from benthic foraminiferal and calcareous nannofossil assemblages (Friedrich et al. 2005), and eustatic sea-level drop consistent with substantial, short-lived glaciation at high latitudes (e.g. Miller et al. 2005). Indian Ocean calcareous nannofossil data suggest that the 
late Maastrichtian was a period of warming (Lees 2002), which is also suggested by Canadian palaeosol $\delta^{13} \mathrm{C}$ data (Nordt et al. 2002).

The very latest Maastrichtian to Early Danian (Early Palaeocene) saw a period of rapid changes in climate, associated with rapid changes in sea-level as indicated by planktonic foraminiferal assemblages (e.g. Keller et al. 2002; Keller 2004). Palaeobotanical data suggest that the Early Palaeocene, 65 Ma (c33, Fig. 1b), was cool at high latitudes with warming by the end of the Danian (Poole et al. 2005). New data suggest that the later Palaeocene was subtropical at high northern latitudes, with a peak across the PalaeoceneEocene boundary (Moran et al. 2006; Sluijs et al. 2006) at 55 Ma, the so-called PalaeoceneEocene thermal maximum (e.g. Zachos et al. 1993; Farley \& Eltgroth 2003). Cooling occurred rapidly in the Early Eocene, $55 \mathrm{Ma}$ (c34, Fig. 1b), heralding the end of this warm mode, with freshening of Arctic Ocean surface waters in the latest Early Eocene, at $~ 49$ Ma, and the first glacially-rafted sediments evident in Arctic Ocean sequences in the early Mid Eocene at $45 \mathrm{Ma}$ (Moran et al. 2006).

Given the range of climate variability during this warm mode summarised above, it could be argued that the deviations from warm climates were more the norm. The short-lived Albian and Late Cretaceous glaciations are of particular interest. They are associated with sharp $(<1$ m.y.) drops in sea-level of up to $80 \mathrm{~m}$ in the Albian (e.g. Immenhauser 2005) and up to $40 \mathrm{~m}$ in the Late Cretaceous (e.g. Miller et al. 2005). The Late Cretaceous examples are also associated with positive $\delta^{18} \mathrm{O}$ excursions of the order of $1 \%$. As Miller et al. (2005) point out, these are comparable to pre-Pleistocene sea-level and $\delta^{18} \mathrm{O}$ changes linked with substantial Antarctic ice caps. Given the recent evidence for large variations in Late Cretaceous atmospheric $\mathrm{CO}_{2}$ concentrations (e.g. Bice et al. 2006), these brief glacial 
excursions are less surprising than they would have been at the time of writing of Frakes et al. (1992). Another transient climatic episode in this warm period, the Palaeocene-Eocene thermal maximum (Zachos et al. 1993), at 55.8 Ma, may at face value seem an odd choice, given that it represents a period of extreme warmth. However, like the PliensbachianToarcian event (e.g. Pálfy \& Smith 2000; Bailey et al. 2003), it occurs towards the end of the warm mode (Zachos et al. 2001) and is followed by a short-lived episode of cooling, in the earliest Eocene (Wing et al. 2000). It is associated with a global strong positive excursion in $\delta^{13} \mathrm{C}$ of $2.5 \%$ (Zachos et al. 1993; Dickens 2000) and sub-tropical Arctic Ocean temperatures (Sluijs et al. 2006). Extraterrestrial ${ }^{3} \mathrm{He}$ data suggest that it had a rapid onset ( $<$ few k.y.) and lasted $\sim 120$ k.y. with possible accelerated drawdown of $\mathrm{CO}_{2}$ from the atmosphere and oceans (Farley \& Eltgroth 2003).

Mid-Palaeogene to Recent cool mode.

This cool mode is perhaps the most intensively studied of all the climate modes described by Frakes et al. (1992), which is reflected by their devoting as many pages to it as all of the other climate modes combined. It differs from preceding climate modes in that continuous and high-resolution proxy records track its changes, e.g. $\delta^{18} \mathrm{O}$ for palaeotemperature (e.g. Zachos et al. 2001; Royer et al. 2004), $\delta^{11} \mathrm{~B}$ for palaeo-pH and palaeo- $\mathrm{CO}_{2}$ (Pearson \& Palmer 2000), Sr/Ca from benthic foraminiferal calcite for weathering fluxes (Lear et al. 2003a), etc. Its beginning is marked by cooling in the early Middle Eocene (Moran et al. 2006), at $\sim 49 \mathrm{Ma}$, following the Palaeocene-Eocene thermal maximum (Zachos et al. 1993). This is slightly later than the Early Eocene proposed by Frakes et al. (1992). In principle, we have not yet reached the end of this cool mode (e.g. Loutre \& Berger 2000), but whether or not we have done so may be dependent on human activities in the near future (e.g. IPCC 2001). 
The present cool mode is marked by an overall cooling trend, reflected in the $\delta^{18} \mathrm{O}$ and fossil plant assemblages, punctuated by a series of sharp changes, culminating in Pleistocene bihemispheric glaciation (Frakes et al. 1992). The earliest evidence of cooling, that marks the beginning of this cool mode, comes from new marine core data from the Arctic Ocean that suggest substantial freshening of ocean waters close to the Early-Mid Eocene boundary (Moran et al. 2006), at 49 Ma. These new data support the onset of Arctic ice-rafting from mid-Mid Eocene times onwards, at $\sim 45 \mathrm{Ma}, 35$ million years earlier than previously assumed (Moran et al. 2006). This earlier evidence for Arctic ice is supported by recent sedimentary and foraminiferal geochemistry data from the Pacific, which suggest that bipolar glaciation was episodically present in the late Mid Eocene from 42 Ma onwards (Tripati et al. 2005).

The first sharp change in this cool mode, represented by major positive excursions of $\sim 1.5 \%$ in $\delta^{18} \mathrm{O}$ and $\sim 1.4 \%$ in benthic $\delta^{13} \mathrm{C}$, and sea-level drops of up to $125 \mathrm{~m}$, occurred at the Eocene-Oligocene boundary (e.g. Tripati et al. 2005), 34 Ma. These changes are interpreted to mark the formation of the first large permanent ice sheets in Antarctica (e.g. Zachos \& Kump 2005), although terrestrial palaeotemperature proxy data suggest that the positive excursion in $\delta^{18} \mathrm{O}$ was more likely to be related to changes in Antarctic ice volume rather than a lowering of palaeotemperatures (e.g. Grimes et al. 2005). Alkenones data suggest that atmospheric $\mathrm{CO}_{2}$ levels were still relatively high at this time, but that they continued to drop though the Oligocene, from 1000-1500 ppmv in the Late Eocene, reaching modern levels by latest Oligocene times (Pagani et al. 2005b).

The Early and early Late Oligocene is marked by cool climates with a series of short-lived positive excursions in the $\delta^{18} \mathrm{O}$ curve (Miller et al. 1991), labelled Oi-1, 1a and 1b, at $\sim 34$ 
Ma, 33 Ma and 32 Ma (e.g. Zachos et al. 2001; Pekar et al. 2002), and Oi-2, 2*, 2a, 2b and 2c at $\sim 30 \mathrm{Ma}, \sim 29 \mathrm{Ma}, \sim 28 \mathrm{Ma}, \sim 27 \mathrm{Ma}$ and $\sim 26 \mathrm{Ma}$ (Pekar et al. 2002; Wade \& Palike 2004). These were associated with sea-level drops of up to $65 \mathrm{~m}$ (Wade \& Palike 2004) and are interpreted to represent oscillating, large-scale Antarctic ice sheets (Zachos et al. 2001). The later Late Oligocene, $\sim 25 \mathrm{Ma}$ (w2, Fig. 1b), shows a brief return to warmer climates in both hemispheres (Barreda \& Palamarczuk 2000; De Man \& Van Simaeys 2004; Villa \& Persico 2006), followed by a return to glacial conditions at the Oligocene-Miocene boundary (e.g. Zachos et al. 2001).

Like the Oligocene, the Miocene is a time of cool climates with a series of short-lived positive excursions in the $\delta^{18} \mathrm{O}$ curve associated with short-lived drops in sea-level (Miller et al. 1991). The first and most major of these, Mi-1 (Miller et al. 1991), is at the OligoceneMiocene boundary, at $\sim 23 \mathrm{Ma}$. This is followed by at least five further $\delta^{18} \mathrm{O}$ stages, Mi-2 to Mi-6 (and substages), at $\sim 16 \mathrm{Ma}, \sim 15 \mathrm{Ma}, \sim 13 \mathrm{Ma}, \sim 12 \mathrm{Ma}$ and $\sim 10 \mathrm{Ma}$ (Miller et al. 1991; Flower 1999). A significant overall positive step in $\delta^{18} \mathrm{O}$ occurred between Mi-2 and Mi-4, between $\sim 16 \mathrm{Ma}$ and $\sim 12 \mathrm{Ma}$ (e.g. Flower 1999), the so-called "mid-Miocene cooling" event, associated with the establishment of a semi-permanent East Antarctic ice sheet and changes in oceanic circulation (e.g. Westerhold et al. 2005). From Mi-6 onwards, sedimentological evidence suggests the presence of glaciation outside Antarctica in both hemispheres (e.g. Denton \& Armstrong 1969; Mercer \& Sutter 1982; Duncan \& Helgason 1998).

As suggested by Frakes et al. (1992), the early Tortonian of the Late Miocene, $11 \mathrm{Ma}$ (w3, Fig. 1b), shows a slight warming of global climates, from, for example, $\mathrm{Mg} / \mathrm{Ca}$ ratios in benthic foraminifera (Lear et al. 2003b). The Late Miocene saw a resumption of significant cooling, from $\delta^{18} \mathrm{O}$ in benthic foraminifera and accompanying sea-level falls, that resulted in 
glaciation during the Messinian of the latest Miocene, between $\sim 6.26$ and $\sim 5.50 \mathrm{Ma}$, although terminating prior to the Miocene-Pliocene boundary (e.g. Hodell et al. 2001), at 5.3 Ma. Extreme desiccation of the Mediterranean basin occurred at this time (e.g. Hodell et al. 1986; Krijgsman et al. 1999). Although glacio-eustatic sea level falls and more arid global climate are contributory factors, the primary driver for isolation of the Mediterranean appears to be tectonic (e.g. Krijgsman et al. 1999; Hodell et al. 2001), particularly as similar tectonicallydriven desiccation episodes affected basins at its western margin shortly before in the Tortonian (Krijgsman et al. 2000).

The very latest Miocene and Early Pliocene, 5.3 Ma, show a return to milder climates (w4, Fig. 1b), as indicated by changes in the $\delta^{18} \mathrm{O}$ of benthic and planktonic foraminifera from the Atlantic (Vidal et al. 2002; Reuning et al. 2006), thermohaline circulation modelling (Ravelo \& Andreasen 2000), and Antarctic glacial sedimentology (Prentice \& Krusic 2005). Climate warming peaked in the mid-Pliocene, between $\sim 3.3 \mathrm{Ma}$ and $\sim 3 \mathrm{Ma}$ (w5, Fig. 1b), and as described by Haywood et al. (2002b), "Earth experienced a significant sustained period of greater global warmth spanning a time frame longer than any interglacial of the Quaternary period". Evidence for this warmth comes from Australian ostracod faunal data (Warne 2005), alkenones palaeothermometry (Haywood et al. 2005), multiproxy analysis of Arctic Ocean ODP core data (Knies et al. 2002) and climate modelling (e.g. Haywood et al. 2000; Haywood et al. 2002a).

In the Late Pliocene, at some point around 2.7 Ma, probably at marine isotope stage G6 ( 2.74 Ma) (Bartoli et al. 2005), global climate cooled. Ocean-bottom nitrogen isotope data (Sigman et al. 2004), alkenone unsaturation ratios and diatom oxygen isotope ratios (Haug et al. 2005), Ge/Si ratios (Lin \& Chen 2002), and ostracod assemblages (Yamada et al. 2005), 
suggest that this was the beginning of full-scale Northern Hemisphere glaciation (e.g. Klotz et al. 2006). It marks the onset of relatively continuous intensifying glacial-to-interglacial cycles to the present day (e.g. Bartoli et al. 2005). Late Pliocene and Early Pleistocene glacial-interglacial cycles show a 41 ky periodicity, probably controlled by the astronomical obliquity cycle (e.g. Park \& Maasch 1993). Between $\sim 1.2$ and $\sim 0.6 \mathrm{Ma}$, centred on $\sim 0.95$ $\mathrm{Ma}$, the so-called mid-Pleistocene climate transition or climate revolution, the periodicity shifted to $100 \mathrm{ky}$ (e.g. Tziperman \& Gildor 2003). This is consistent, temporally, with control by the precessional cycle, although the variation in insolation associated with this cycle appears to be too small compared with the associated significant increase in the intensity of Northern Hemisphere glaciation and increase in amplitude of glacial-interglacial intervals (e.g. Winckler et al. 2004). Evidence for this change comes from positive excursions in oceanic $\delta^{13} \mathrm{C}$ (Raymo et al. 1997; Wang et al. 2004), global eustatic sea-level fall (Kitamura \& Kawagoe 2006), mass extinctions of benthic foraminifera (Hayward 2001; Kawagata et al. 2005; Kawagata et al. 2006), and the onset of major glaciation in the European Alps (Muttoni et al. 2003). The final stages of this transition are associated with unusual deposition of diatomaceous, carbonaceous and carbonate sediments in the South Atlantic and Mediterranean (Schmieder et al. 2000; Gingele \& Schmieder 2001).

No particularly notable intervals of contrasting climate mark this cool mode. The Late Oligocene, $\sim 25 \mathrm{Ma}$, mid-Miocene, $\sim 11 \mathrm{Ma}$, and latest Miocene-Early Pliocene, $5.3 \mathrm{Ma}$ milder intervals (w2-4, Fig. 1b) are mainly of note because they briefly offset the overall cooling trend). The "mid-Miocene cooling" event between Mi-2 and Mi-4, $16 \mathrm{Ma}-12 \mathrm{Ma}$ (e.g. Flower 1999) is interesting because the early stages coincide with eruption of the Columbia River basalts between $\sim 16.1$ and $\sim 15$ Ma (Hooper et al. 2002), which is the most recent large igneous province eruption known. The only interval comparable to the 
Palaeozoic Kazimovian warm interval is, perhaps, the mid-Pliocene warm interval (w5, Fig. 1b), which had sea levels higher than today and East Antarctic climates similar to modernday Chile (Haywood et al. 2002b).

\section{Major Phanerozoic controls on climate}

\section{Long-term secular variation in the carbon cycle}

The carbon cycle, with its links to biological and tectonomagmatic activity, is extremely important for the long-term evolution of climate in the Phanerozoic. The geochemically modelled atmospheric $\mathrm{CO}_{2}$ curves of Berner (e.g. Berner \& Kothavala 2001; Berner 2003a) (Fig. 3a) indicate that $\mathrm{pCO}_{2}{ }^{\text {atm }}$ was high in the Early Palaeozoic, low during PermoCarboniferous times, relatively high again in the Mesozoic, and that it has been in decline since then. Although the relationship between palaeotemperature and $\mathrm{pCO}_{2}{ }^{\mathrm{atm}}$ is less clear at the very highest concentrations seen during the Mesozoic (Bice et al. 2006), there is general agreement of a positive correlation between $\mathrm{pCO}_{2}{ }^{\text {atm }}$ and global average temperature (e.g. Kump 2002; Retallack 2002; Royer et al. 2004; Siegenthaler et al. 2005). Examination of the curve of Berner (2003a), (Fig. 3a) and comparison with the palaeotemperature analysis by Royer et al. (2004) (Fig. 3b), suggests that Phanerozoic climate can be subdivided into longterm, fluctuating high $\mathrm{CO}_{2}$ modes, interleaved with shorter-term low $\mathrm{CO}_{2}$ modes (Fig $1 \mathrm{~b}$ ). Similarly, Raymond \& Metz (2004) suggested that for Phanerozoic glaciation there are shortterm, overall high $\mathrm{CO}_{2}$ glacial modes, such as during the Late Ordovician and Cretaceous (Fig. 1b), and longer-term, low $\mathrm{CO}_{2}$ glacial modes, such as in the Permo-Carboniferous and Late Cenozoic (Fig. 1b).

Of course, something that is not always expressed is what constitutes high or low $\mathrm{pCO}_{2}{ }^{\text {atm }}$ levels and where the threshold lies. Royer et al. (2004) suggested that levels above 1000 
ppmv should be considered as high and below that should be considered as low, with a transitional range between about 600 and 1000 ppmv. A brief examination of the geological record suggests that this is reasonable. The earliest Cenozoic Antarctic glaciation, Oi-1 at the beginning of the Oligocene (e.g. Tripati et al. 2005), began when atmospheric $\mathrm{CO}_{2}$ levels were at about 1000 parts per million and falling (Pagani et al. 2005b); recent data suggests that carbon dioxide levels in the cool Early Cretaceous were of the order of 560 to 1200 parts per million (Haworth et al. 2005), compared with up to $2400 \mathrm{ppmv}$ for the warmer Late Cretaceous (Bice et al. 2006).

\section{Tectonism}

A key driver of long-term variability in atmospheric $\mathrm{CO}_{2}$ is the amalgamation and fragmentation of continents, the so-called supercontinent cycle (e.g. Condie 2002; Murphy \& Nance 2005). Major orogenic events (Fig. 4a), which exhume deep levels of the continental crust, have been proposed as drivers of major draw-down of atmospheric $\mathrm{CO}_{2}$ (Raymo 1991; Hay 1996). These are associated with changes in palaeoelevation (e.g. Ruddiman \& Kutzbach 1991), weathering rates (Raymo 1991), atmospheric circulation (Gunnell 1998) and atmospheric dustiness (e.g. Kohfeld \& Harrison 2000). Silicate weathering products added to the ocean from the current orogenic belt that extends from Papua New Guinea to the Pyrenees, and includes the Himalayas, have been implicated in the overall decline of atmospheric $\mathrm{CO}_{2}$ levels during the Late Palaeogene and Neogene and the onset of global glaciation (Raymo 1991), although modelling suggests that the net effect is not sufficient to explain the degree of cooling observed (Kerrick \& Caldeira 1999).

The current phase of the supercontinent cycle is one of amalgamation (Fig. 4a), which is a likely time of major orogenesis. Similarly, in the Permo-Carboniferous, Pangaea was amalgamating (e.g. Veevers 2004), resulting in the Hercynian-Alleghenian-Uralian orogeny 
(Fig. 4a), comparable in scale, duration, and rate of exhumation, to the modern-day collisional orogenic belt described above. Although the situation is slightly complicated by the rapid evolution of land plants in the Permo-Carboniferous, the addition of silicate weathering products to the Palaeo-Tethyan and Panthallassan oceans was likely to have been key in the large-scale decline of atmospheric $\mathrm{CO}_{2}$ levels. Conversely, the rifting phase of Pangaea in the Jurassic was associated with elevated rates of $\mathrm{CO}_{2}$ degassing (Kerrick 2001). Fig $3 \mathrm{a}$ and $3 \mathrm{~b}$ suggest that there is a relatively good correlation between orogenesis that results in the amalgamation of supercontinents and low- $\mathrm{CO}_{2}$ climate modes. Other orogenic events do not seem to correlate in time with cool episodes. The correlation with "aragonite" and "calcite" seas (Hardie 1996) (Fig. 4b) suggests that this is more closely linked to the supercontinental cycle with only very indirect influence on climate.

Another important aspect of tectonic changes over shorter timescales is the opening and closing of oceanic gateways (e.g. Smith \& Pickering 2003) (Fig. 5) and change in the configuration of land and sea (e.g., Barron et al. 1980; Ramstein et al. 1997). The opening of the Drakes Passage and Tasman gateways in the earliest Oligocene (Fig. 5) has been implicated in the onset of Antarctic isolation through initiation of the Antarctic Circumpolar Current (Livermore et al. 2004; Mackensen 2004). Very shortly afterwards, in the Early Oligocene, subsidence of the Greenland-Scotland ridge is suggested to be the trigger for the onset of North Atlantic deep water formation and the beginning of the modern thermohaline circulation (Via \& Thomas 2006). In the middle Miocene, closure of the Panamanian gateway between North and South America appears to have triggered the major cooling step at that time (e.g. von der Heydt \& Dijkstra 2006). Full-scale Northern Hemisphere glaciation may have followed as a result of advection of warmer waters northwards, with increased delivery of moisture to high latitudes (e.g. Lear et al. 2003b). Further back in time plate 
configurations are much less certain. Nevertheless, opening and closing of gateways during the final amalgamation of Pangaea in the Permian have been linked to climate changes at that time (Saltzman 2003).

\section{Magmatism}

A major source of variation in the rate of addition of juvenile, mantle-derived $\mathrm{CO}_{2}$ to the atmosphere and oceans is the rate of eruption of magmatic large igneous provinces (LIPs), volcanic eruption cycles with volumes greater than $100,000 \mathrm{~km}^{3}$ of magma, which appear to have a $\sim 170$ million year cyclicity over the past 1500 million years (Prokoph et al. 2004). McElwain et al. (2005) have suggested that LIP eruptions also add substantial $\mathrm{CO}_{2}$ by intruding into coal seams. Enhanced rates of magmatism, particularly associated with superplume episodes, such as in the Cretaceous (Larson 1995), are implicated in intervals of high $\mathrm{CO}_{2}$ (Caldeira \& Rampino 1991). The LIP record for the Phanerozoic is biased towards the record of terrestrial LIP eruptions (Fig. 6). Consequently the record is much more complete for the period after 170 million years ago, when the presently interrogateable seafloor record began. The Jurassic-Cretaceous, Mesozoic peak in LIP emplacement (Fig. 6), the most recent peak in the superplume cycle, is well represented in the geological record and coincides with a relative peak in atmospheric $\mathrm{CO}_{2}$ and some of the highest global temperatures in the Phanerozoic (Vaughan \& Storey in press).

The record for LIP emplacement pre-170 million years ago is much more sketchy. Some Late Triassic and Early Jurassic oceanic LIPs have been recognised (e.g. Vaughan \& Storey in press), but that is as far back as the record of oceanic LIPs extends, so far. Earlier LIPs are all terrestrial, and largely recognised from dyke swarms rather than basalt or rhyolite lavas 
(Ernst et al. 2005). In Figure 6, LIP eruptions through the Phanerozoic are plotted by area (Fig. 6a) and by volume (Fig. 6b). Volume is one of the key parameters required to assess the impact of a LIP, but volumes are difficult to obtain for LIPs older than Early Jurassic. Dyke swarm extent gives a proxy for area for older LIPs, so for Phanerozoic-length timescales it is useful to examine LIPs by erupted area. For the Mesozoic, there is a striking time coincidence in some cases between LIP eruptions and cool or glacial episodes, e.g. the Siberian Traps, Karoo magmatism and Shatsky Rise LIP (Fig. 6a).

If basaltic LIP eruptions are possible drivers of elevated global temperature, silicic LIPs and super-eruptions appear to be associated with global cooling. For example, Briffa et al. (1998) showed a strong correspondence between large silicic eruptions over the past 600 years and severe Northern Hemisphere winters based on maximum latewood density in tree rings. Over longer timescales, Rampino \& Self (1992) suggested that the Toba super-eruption 73,500 years ago accelerated the Oxygen Isotope Stage 5a to 4 interglacial to glacial transition, and Prueher \& Rea (1998) suggested that a 10-fold increase in volcanicity in the North Pacific 2.67 million years ago coincided with an intensification of Late Pliocene continental glaciation. Farther back in time, the Early and early Middle Jurassic period of Gondwana break-up silicic LIP eruptions (Fig. 6a) coincide with a period of four glacial episodes over that interval (Fig. 1b). Modelling by Jones et al. (2005) suggests that the silicic magmatism is insufficient on its own to trigger glaciation, although deviation from normal temperatures may last decades. The evidence suggests that cooling associated with silicic eruptions may act as an intensifier in the onset of glaciation where other conditions are favourable. 
The rate of obduction of ophiolites (Fig. 7a), a slice of ocean floor added to continental margins rather than being subducted, has also been suggested as a proxy for peaks in the superplume cycle (Vaughan \& Scarrow 2003). Again, as with LIP eruptions, from Fig. 7a, there is a striking positive time correlation between ophiolite obduction pulses and Palaeozoic and Mesozoic cool intervals, particularly for the Steptoan in the Cambrian (c2, Table 1), the Tremadocian in the Early Ordovician (c3, Table 1), mid and Late Jurassic intervals, and the Late Cretaceous and Palaeogene.

The rate of eruption of kimberlites (Fig. 7b), also a significant source of juvenile $\mathrm{CO}_{2}$, appears to correlate positively with the rate of basaltic LIP emplacement. At face value, kimberlites volumes appear too small to perturb the $\mathrm{CO}_{2}$ balance of the atmosphere and oceans for more than a few years. However, there is a good general positive correlation, visible on Fig. 7 b, between peaks in kimberlite eruption rate and high- $\mathrm{CO}_{2}$ climate intervals and lulls in kimberlite eruption rates and low- $\mathrm{CO}_{2}$ climate modes, which suggests that they may have a more significant and longer-term effect.

Overall, these proxies, in conjunction with the $\mathrm{CO}_{2}$ and sea-floor record, suggest a major peak in oceanic LIP emplacement during the Cambro-Ordovician, even in the absence of surviving direct evidence. These LIPs were probably oceanic, as were most of the Cretaceous LIPs, and constitute the early Palaeozoic superplume event proposed by Larson (1991) and Barnes (2004). Significant LIP emplacement intervals, also probably representing superplume events, although on a smaller scale than the Mesozoic and Cambro-Ordovician events, have also been suggested for the Late Carboniferous-Early Permian (e.g. Larson 1991; Doblas et al. 1998) and Late Permian (e.g. Medvedev et al. 2003). 


\section{Biological evolution}

The evolution of land plants with complex root systems caused a major change in atmospheric composition (e.g. Berner 1998) and the evolutionary rise in land plants has been strongly implicated in the severity of the long-term $\mathrm{CO}_{2}$ reduction during the PermoCarboniferous low- $\mathrm{CO}_{2}$ interval and global glaciation (e.g. Berner 2003b; Igamberdiev \& Lea 2006). Plants increased the rate of continental silicate weathering rates, enhancing the drawdown of $\mathrm{CO}_{2}$ in the oceans as carbonate; organic acids generated by plant roots are significant agents of silicate weathering (Caldeira 2006). Aided by actively subsiding basins and many cycles of glacio-eustatic sea level rise and fall, or cycles of humidity-aridity, plants also directly contributed to the removal of $\mathrm{CO}_{2}$ from the atmosphere by forming peat, which was subsequently turned to coal (e.g. Heckel 1996). Similar suggestions for the Cenozoic have been made with regard to the rise of the angiosperms (Igamberdiev \& Lea 2006).

Another major change happened in the Late Triassic with the evolution of plankton capable of fixing carbonate to form hard skeletons, allowing the deep oceans to become a significant sink for carbonate (e.g. Ridgwell 2005; Erba 2006). This was initiated by the change from dominance in the oceans of phytoplankton with green algal plastids, e.g. acritarchs, to those with red algal plastids, e.g. coccolithophorids, at the Permian-Triassic boundary (Grzebyk et al. 2003) culminating in the Late Triassic (e.g. Ridgwell 2005). Prior to this, carbonate fixing was carried out in continental shelf areas by largely benthic and infaunal organisms (e.g. Ridgwell 2005). Major drops in sea level in pre-Mesozoic time, by diminishing shelf area, drastically reduced the capacity of the Earth system to sequester carbon as carbonate, a regulated and buffered process by comparison with the more rapid drawdown of $\mathrm{CO}_{2}$ as organic carbon, saturating the oceans (Ridgwell 2005). Since the Late Triassic, only at times 
of probable ocean acidification do we see a return to the Palaeozoic and Early Mesozoic mechanism, and, in addition to the swings in climate, sea-level, and isotopic systems described above, this is commonly associated with mass extinction of organisms, for example, at the Cretaceous-Palaeogene boundary (e.g. Hollander et al. 1993). However, the relationship between carbonate and organic carbon formation and atmospheric $\mathrm{CO}_{2}$ is complex and still not well understood (see Barker et al. 2003 for a recent review)

\section{Astronomical controls}

Changes in insolation driven by the Earth's orbital parameters of precession, obliquity and eccentricity, have long been recognised as important drivers of climatic change, if only widely accepted in the last 30 years (e.g. Croll 1867; Milankovitch 1941; Hays et al. 1976; Zachos et al. 2001; Berger \& Loutre 2004). These occur on $19 \mathrm{ky}, 41 \mathrm{ky}$, and $100 \mathrm{ky}$ frequencies, respectively. Additionally, there are so-called "grand" cycles related to the orbits of the major planets with periodicities at the present day of $400 \mathrm{ky}$, and 1.25, 2.35 and 4.6 My (e.g. Olsen 2001). Modelling based on Milankovitch theory has been applied with varying degrees of success to explanation of cyclical climate variations for much of the Neoproterozoic (e.g. Lewis et al. 2003) and Phanerozoic (e.g. Herrmann et al. 2003; Wade \& Palike 2004; Holbourn et al. 2005; Huynh \& Poulsen 2005). These studies suggest that insolation minima of the orbital cycles are the likely trigger for glaciation at low $\mathrm{CO}_{2}$ levels at long and short timescales. The effects of long-term changes in the intensity of insolation at the peaks of the Milankovitch cycle are not known, but may be a significant factor in longerterm climate change.

Although the sun is recognised as a short-term variable (Solanki \& Krivova 2004), the influence of variation in solar output at longer timescales, although potentially an extremely 
important driver of climate change (e.g., Walker et al. 1981), is currently difficult to model or quantify. For example, Foukal et al. (2006) have shown that variations in the Sun's brightness (solar luminosity) caused by changes in sunspot area are insufficient to account for warming since the Little Ice Age; however, they point out that additional climate forcing by variations in solar ultraviolet output or the solar wind cannot be ruled out. Apart from the obvious effect of variation in insolation, solar activity, via accompanying changes in the strength of the Sun's magnetic field, may also inversely affect the galactic cosmic ray flux (Usoskin et al. 2005), with possible implications for low-level cloudiness (e.g. Yu 2002; Harrison \& Stephenson 2006). For example, Ramirez et al. (2006) have suggested that cosmic ray modulated variation in low-level cloud cover may be responsible for temperature changes up to $50 \%$ that predicted for doubling of atmospheric $\mathrm{CO}_{2}$. In terms of variations in solar output and insolation at the Earth's surface, a study of sunspot activity for the Holocene, using dendrochronologically-dated variations in ${ }^{14} \mathrm{C}$, suggests that current solar activity is at its highest for 11,000 years (Solanki et al. 2004).

Variations in the galactic cosmic ray flux as a function of the location of the solar system relative to the spiral arms of the galaxy has been implicated as a driver of long-term climate change (Wallmann 2004; Wendler 2004; Shaviv 2005). Figure 8 shows a summary of the warm and cool modes of Frakes et al. (1992) for the last 600 million years, overlain by blocks showing likely periods of enhanced galactic cosmic ray flux of Wallmann (2004). Interestingly, there appears to be a loose time correlation between peaks in the galactic cosmic ray flux and protracted periods of Phanerozoic glaciation (Wallmann 2004). However, this is less clear for high- and low- $\mathrm{CO}_{2}$ climate modes (Fig. 8b). Mechanisms proposed to explain links between galactic cosmic ray flux and climate include the reflective and cooling effects of enhanced low-level cloudiness nucleated by cosmic rays penetrating 
the atmosphere (Shaviv 2005). However, Royer et al. (2004) showed that a pH-corrected Phanerozoic palaeotemperature curve predicts proxy-based cool and warm epochs more accurately than predicted variation in galactic cosmic ray flux (Shaviv \& Veizer 2003).

Figure 8 suggests that, stochastically, the periodicity of changes in the galactic cosmic ray flux and the more closely coupled supercontinent and superplume cycles have been partially in step, although not in any way coupled, during the Phanerozoic. Galactic cosmic ray flux mechanisms for global cooling (e.g. Shaviv \& Veizer 2003) may have at times intensified major glaciations, but are unlikely to be directly responsible for them. Interestingly, Evans (2003) has pointed out that, taking into account preservational bias, sedimentological or isotopic evidence for major global glaciation is absent between the 2.5-2.2 Ga Palaeoproterozoic Huronian glaciation and the Neoproterozoic "Snowball Earth" glaciations of $\sim 750$ million years ago (Evans 2000). One outside possibility is that peaks in the galactic cosmic ray flux and periods of low- $\mathrm{CO}_{2}$ (lows in the superplume cycle and times of supercontinental amalgamation) were out of phase during the later Palaeoproterozoic to early Neoproterozoic interval, moderating the severity of low- $-\mathrm{CO}_{2}$ mode glaciation.

\section{Other mechanisms}

Studies of the chemical composition of evaporite deposits and of fluid inclusions in halite (e.g. Hardie 1996; Lowenstein et al. 2001) suggest that the carbonate composition of seawater has varied systematically through the Phanerozoic, alternating between "aragonite seas", as at the present day, and "calcite seas" (e.g. Hardie 1996; Berner 2004) (Fig. 4c), such as in the Cretaceous. It has been argued that these changes in composition are variously related to rates of magmatic or hydrothermal activity at spreading ridges, changes in $\mathrm{Mg} / \mathrm{Ca}$ ratio, and $\mathrm{pCO}_{2}$ (summarized in Adabi 2004). As summarized by Erba (2006), a broad general relationship is evident with aragonite seas during periods of supercontinental 
amalgamation and relatively low hydrothermal activity at spreading ridges, i.e. relatively low- $\mathrm{CO}_{2}$ intervals, and calcite seas during periods of high hydrothermal activity at spreading ridges and at times of supercontinental dispersal, i.e. relatively high- $\mathrm{CO}_{2}$ intervals.

Dissociation of seabed methane hydrate deposits (e.g. Nisbet 1992; Hesselbo et al. 2000), or high latitude permafrost-hosted methane hydrate deposits (e.g. Nisbet 2002), is implicated in generating peaks in atmospheric $\mathrm{CO}_{2}$, with accompanying palaeotemperature rises, and paired negative-positive spikes in $\delta^{13} \mathrm{C}$ (e.g. van de Schootbrugge et al. 2005). The proposal is that, destabilised by warming of ocean waters (e.g. Thomas et al. 2002a), or decompression caused by a drop in sea-level (e.g. Maslin et al. 2005), methane hydrate deposits in shelf sediments catastrophically decrepitate. This transfers large volumes of isotopically-light, up to $-60 \% \delta^{13} \mathrm{C}$, carbon as methane to the atmosphere (e.g. Zachos et al. 2005). Methane is a powerful greenhouse gas in its own right (Badr et al. 1992), so this initial release may cause a pulse of global warming, but atmospheric chemistry models suggest that the methane rapidly oxidizes to $\mathrm{CO}_{2}(<10$ years, Nisbet pers. comm.. 2006), prolonging the elevation of temperatures. The increase in atmospheric $\mathrm{CO}_{2}$ triggers a rise in ocean productivity, initially resulting in a negative spike in $\delta^{13} \mathrm{C}$, which progresses to more positive values as drawdown of $\mathrm{CO}_{2}$ continues (Jenkyns 2003).

Methane hydrate dissociation has been proposed as the mechanism for events at the boundaries of the Permian-Triassic (e.g.Winguth \& Maier-Reimer 2005), PliensbachianToarcian (Hesselbo et al. 2000) and Palaeocene-Eocene (Dickens 2000). The PermianTriassic event coincided with the eruption of the Siberian Traps (a major basaltic and silicic LIP) (Wignall 2001) and the Early Jurassic methane hydrate release was also coincident with 
major LIP eruptions 183 Ma (Fig. 6a) associated with the onset of Gondwana break-up (Vaughan \& Storey in press).

\section{Discussion}

Examination of the curves of Berner \& Kothavala (2001), review of the geological data presented above, and comparison with the palaeotemperature analysis by Royer et al. (2004) suggests an alternative to the warm and cool modes of Frakes et al. (1992). As outlined in Table 1 and Fig. 1b, I propose that there are long-term high $\mathrm{CO}_{2}$ warm modes to Phanerozoic climate, punctuated by short-lived contrasting cool or glacial intervals, and shorter term low $\mathrm{CO}_{2}$ cool modes, such as the current Oligocene-Recent interval, with rarer contrasting shortlived warm intervals, that culminate in times of major global glaciation, or superglaciations.

Examination of the geological record of cool and warm climates, as summarized in Table 1, Fig. 1b, and Figs 3,4,6 \& 7, would suggest that, high $\mathrm{CO}_{2}$ modes, which have a predominance of warm climates, coincide with peaks in the superplume cycle, i.e. with high rates of emplacement of LIPs, and coincide with periods of continental dispersal in the supercontinent cycle. These are periods of high rates of magmatic activity and elevated hydrothermal activity at mid-ocean ridges. Although the correlation is not perfect, high $\mathrm{CO}_{2}$ modes also loosely coincide with "calcite" seas. Overall, these modes are times of high $\mathrm{CO}_{2}$ flux and relatively low rates of continental weathering.

Low $\mathrm{CO}_{2}$ modes, which are generally of much shorter duration, appear to coincide with lulls in the superplume cycle, i.e. with very low rates of LIP emplacement (Fig. 6). They coincide with periods of amalgamation in the supercontinent cycle with very large-scale orogenesis and high rates of crustal exhumation (Fig. 4). These are periods of relatively low rates of 
magmatic activity and low rates of hydrothermal activity at mid-ocean ridges. Again, although the correlation is not perfect, low carbon dioxide modes approximately with "aragonite" seas. Overall, these modes are times of relatively low $\mathrm{CO}_{2}$ flux and elevated rates of continental weathering.

Of particular interest are the periods of contrasting climate (summarised in Table 1). High $\mathrm{CO}_{2}$ modes are punctuated by frequent short-lived cool or glacial episodes. Low $\mathrm{CO}_{2}$ modes, on the other hand, only rarely experience short-lived warming episodes, such as that in the mid-Pliocene. The short-lived cool or glacial episodes in high $\mathrm{CO}_{2}$ modes have some common characteristics. They generally occur at times of eustatically high sea level, but are marked by a rapid drop in sea level, such as in the Late Callovian (Dromart et al. 2003). They are preceded by or overlap with episodes of deposition of carbonaceous sediments, such as black shales or sapropels, such as in the Turonian (Wilson et al. 2002; Bice et al. 2006). Where reliable isotope data can be extracted, such as for the Mesozoic and early Cenozoic, they are also associated with positive excursions in $\delta^{13} \mathrm{C}$ and $\delta^{18} \mathrm{O}$, again seen in the Late Callovian (Dromart et al. 2003).

\section{A modified scheme of climate modes for the Phanerozoic}

The Earliest Cambrian to mid-Ordovician, Late Ordovician to Early Silurian and Late Silurian to mid-Early Carboniferous climate modes of Frakes et al. (1992) (warm-cool-warm respectively) coincided with the early Palaeozoic high- $\mathrm{CO}_{2}$, climate mode (Table 1, Fig. 1b), which was largely warm with $\mathrm{CO}_{2}$ concentrations fluctuating on short timescales. As suggested above, this high- $\mathrm{CO}_{2}$ mode can probably be extended back into the Ediacaran of the late Neoproterozoic. This is based on the analysis of Royer et al. (2004), and the $\mathrm{CO}_{2}$ curve of Berner (2003a). It largely overlaps with the early Palaeozoic "calcite" sea (e.g. 
Holland 2004), indicating a time of high hydrothermal activity at spreading ridges and continental dispersal. As discussed above, proxy data suggest that this is an interval of a peak in the superplume cycle with elevated rates of LIP eruptions.

Of the short-lived cool, possibly glacial, phases during this high- $\mathrm{CO}_{2}$ mode, the Ediacaran short-lived glacial interval at $\sim 580 \mathrm{Ma}$ (c1, Fig. 1b; Table 1) coincides with the inception of the Middle Iapetus LIP of Ernst \& Buchan (2001). Eruption of the Kalkarindji LIP in Australia (Glass \& Phillips 2006) overlaps with the Middle Cambrian, Steptoan positive $\delta^{13} \mathrm{C}$ excursion, major sea-level drop and probable short-lived glacial episode (e.g. Saltzman et al. 2000) (c2, Fig. 1b; Table 1).

For the short-lived cool or glacial periods in the early Ordovician, late Ordovician, and Early Silurian (c3-c10, Fig. 1b; Table 1), there are no recorded episodes of basaltic LIP magmatism, although indirect proxy evidence suggests that they were likely. The late Ordovician Hirnantian glaciation (c7, Fig. 1b; Table 1) was probably the most severe and is associated, although not simultaneously, with black shale deposition and a mass extinction event (Marshall et al. 1997). The three Early Silurian glaciations (Kaljo et al. 2003) (c8-c10, Fig. 1b; Table 1) do coincide with an inferred period of elevated global silicic volcanism, mainly represented by thick bentonite horizons, representing individual explosive eruptions of up to 1000 cubic kilometres each (Fortey et al. 1996). These may have resulted in short periods of global cooling, as suggested for explosive eruptions during the past 600 years (e.g. Briffa et al. 1998), or have acted as a trigger for glaciation (e.g. Rampino \& Self 1992; Jones et al. 2005). 
During the latter part of this high- $\mathrm{CO}_{2}$ mode, short-lived glaciation is associated with black shale deposition, sea level changes and mass extinction in the Late Devonian, the Kellwasser event of the Frasnian-Famennian (Buggisch 1991) (c11, Fig. 1b; Table 1), and at the Devonian-Carboniferous boundary, the Hangenberg event (Caplan \& Bustin 1999) c12, Fig. 1b; Table 1). This latter event coincides with the eruption of the Yakutsk-Baltica LIP (Fig. 6a), one of the largest known LIPs of the Palaeozoic. A final phase of short-lived glaciation occurred in the Visean of the Early Carboniferous (e.g. Eyles 1993) (c13, Fig. 1b; Table 1).

The following late Palaeozoic cool, low- $\mathrm{CO}_{2}$ mode (Table 1, Fig. 1b) coincides with the Permo-Carboniferous cool mode of Frakes et al. (1992) and was a period of superglaciation. It coincided with a peak of orogenesis in the supercontinent cycle, with activity along the Alleghenian-Hercynian-Uralian orogeny as Pangaea finished amalgamating (e.g. Veevers 2004). It coincided with the late Palaeozoic "aragonite" sea (e.g. Holland 2004), indicating a time of low hydrothermal activity at spreading ridges and continental amalgamation. This low- $\mathrm{CO}_{2}$ mode occurs at a low in the superplume cycle, with only one LIP recognised in the Late Carboniferous and Early Permian (Kazimovian-Artinskian) (Doblas et al. 1998). This low- $\mathrm{CO}_{2}$ cool mode is punctuated by only one short-lived warm interval, in the Kazimovian (Bruckschen et al. 1999) (w1, Fig. 1b; Table 1), which precedes the peak in PermoCarboniferous superplume magmatism (Doblas et al. 1998) (Fig. 6a). Warming in the Kazimovian was associated with mass extinction of land plants (Edwards 1998).

The mid-Phanerozoic warm, high- $\mathrm{CO}_{2}$ mode (Table 1, Fig. 1b) incorporates the Latest Permian to Early Jurassic, Middle Jurassic to Early Cretaceous, and Late Cretaceous to Palaeocene climate modes of Frakes et al. (1992) (warm-cool-warm, respectively). Like the early Palaeozoic high- $\mathrm{CO}_{2}$ mode, this mode was largely warm with $\mathrm{CO}_{2}$ concentrations 
fluctuating on short timescales. This mode occurs during a period of continental dispersal following the break-up of Pangaea and Gondwana from Early Jurassic times onwards. It overlaps with the Mesozoic to Palaeogene "calcite" sea (e.g. Holland 2004), indicating a time of high hydrothermal activity at spreading ridges and continental dispersal. Direct magmatic evidence suggests that this is an interval of a peak in the superplume cycle with elevated rates of continental and oceanic LIP eruptions (Vaughan \& Storey in press). At least 25 LIPs erupted between early Jurassic times and the Late Palaeocene, many of which coincided with cool or glacial intervals (Fig. 6a). The short-lived cooler episodes in this warm, high- $\mathrm{CO}_{2}$ mode (Table 1, Fig. 1b) are associated with black shale deposition, oxygen and carbon isotope excursions, sea-level changes and mass extinctions.

Notable events occurred in the Late Permian (c14, Fig. 1b; Table 1), associated with the eruption of the Emeishan Traps and the Guadalupian-Lopingian mass extinction event (Wignall 2001), in the earliest Triassic (c15, Fig 1b, Table 1) associated with the eruption of the Siberian Traps and the largest mass extinction of the Phanerozoic (e.g. Reichow et al. 2002), and in the Late Triassic and Early Jurassic (c16-c21, Fig. 1b; Table 1), associated with emplacement of the Central Atlantic Magmatic Province and Gondwana Large Igneous Province and several mass extinction events (summarised in Vaughan \& Livermore 2005). Further events occurred throughout the Jurassic and Cretaceous and in the Late PalaeoceneEarly Eocene (c22-c34, Fig. 1b; Table 1). Mid-Cretaceous LIP eruptions are not particularly noted for mass extinction events, although these LIPs were largely submarine and oceanic, which may have reduced their impact on the biosphere (Wignall 2001).

The Cenozoic cool, low- $\mathrm{CO}_{2}$ mode (Table 1, Fig. 1b) is equivalent to the Early Eocene to present cool mode of Frakes et al. (1992), and like the late Palaeozoic low- $\mathrm{CO}_{2}$ mode is also 
a time of superglaciation. It coincides with a peak of orogenesis in the supercontinent cycle, with Cenozoic activity along the orogenic belt that extends from the Pyrenees to Papua New Guinea, and includes the Himalayas, as a new supercontinent forms. Orogenesis is also active along the western margin of the Americas (Dickinson 2004; Sobolev \& Babeyko 2005). This cool mode occurs during the current "aragonite" sea (e.g. Holland 2004), indicating a time of low hydrothermal activity at spreading ridges. This low- $\mathrm{CO}_{2}$ mode occurs at a low in the superplume cycle, with only two small LIPs having erupted in the last 50 million years: the Ethiopian traps, which erupted $\sim 30$ million years ago (Hofmann et al. 1997), and the Columbia River basalts $\sim 16$ million years ago (Hooper et al. 2002). This low$\mathrm{CO}_{2}$ cool mode is punctuated by four short-lived warm intervals (w2-w5, Fig. 1b; Table 1), in the Late Oligocene, Late Miocene, latest Miocene-Early Pliocene and mid-Pliocene (midNeogene) (Table 1, Fig. 1b).

\section{Conclusions}

Emanuel (2002) observed that although climate appears to be sensitive to small orbitally driven changes in insolation, often with abrupt consequences, it is on another level stable, in that it has shown only relatively small variations despite an almost $30 \%$ increase in solar output since formation of the Earth 4,560 million years ago. Emanuel (2002) suggested that the climate may have a limited series of overlapping stable regimes that result in more than one equilibrium state for the same insolation conditions. This has also been modelled for the thermohaline circulation (Marotzke \& Willebrand 1991), and was suggested by Chamberlin (1906) in the early $20^{\text {th }}$ Century. A review of the palaeoclimatic evidence suggests that through the Phanerozoic two overlapping stable climate regimes appear to have dominated: a high- $\mathrm{CO}_{2}$, largely warm climate regime, punctuated by short-lived episodes of glaciation 
driven by negative-feedback processes in the carbon cycle; and a low- $\mathrm{CO}_{2}$, largely cool regime, marked by protracted episodes of superglaciation. Other stable regimes are obviously possible, the most recent of which were seen during the low-latitude, "Snowball Earth" global glaciations of the Neoproterozoic (e.g. Hoffman et al. 1998).

\section{The future}

From a proxy point of view, a major gap in the arsenal of techniques available to scientists is a simple and reliable one for marine salinity, particularly given its importance for the density of ocean waters and the control on deep ocean circulation (Henderson 2002). Given the success of the crenarchaeotal-lipid-membrane-based Tex86 proxy for palaeotemperature (Schouten et al. 2002), perhaps the halophile euryarchaeota, which are widely present in terrestrial and marine environments (e.g. Elshahed et al. 2004; Herndl et al. 2005), may provide a palaeosalinity equivalent. A gap also exists for good proxies of global oceanic alkalinity and weathering (Henderson 2002), which exert a key control on $\mathrm{CO}_{2}$ drawdown. From a modelling point of view, the way forward, given the steady increase in computer processing power, is almost certainly towards increasingly coupled GCMs. The most ambitious plans, at the time of writing, aim to couple biome and ice sheet models with coupled ocean-atmosphere GCMs (e.g. Haywood et al. 2002b). Model evaluation with the highest-quality proxy data from the geological record is the only way that we can increase our confidence in model outputs, an essential for anticipating future climates, as outlined by Kump (2002). From a geological point of view, the recent success of the Integrated Ocean Drilling Program Arctic Coring Expedition to the Lomonosov Ridge (Brinkhuis et al. 2006; Moran et al. 2006; Sluijs et al. 2006) illustrates the continued importance of coring the ocean 
basins. Drilling programmes are planned in both polar regions and the importance of this cannot be overstated.

\section{Acknowledgments}

Euan Nisbet and Jan Zalasiewicz are thanked for constructive and insightful reviews that helped refine many of the topics presented here.

\section{References}

Adabi, M.H. 2004. A re-evaluation of aragonite versus calcite seas. Carbonates and Evaporites, 19 (2), 133-141.

Adams, K.D. 2003. Estimating palaeowind strength from beach deposits. Sedimentology, 50 (3), 565-577.

Agassiz, L. 1828. On the erratic blocks of the Jura. Edinburgh New Philosophical Journal, 24, 176-179.

Agustsdottir, A.M., Barron, E.J., Bice, K.L., Colarusso, L.A., Cookman, J.L., Cosgrove, B.A., De Lurio, J.L., Dutton, J.F., Frakes, B.J., Frakes, L.A., Moy, C.J., Olszewski, T.D., Pancost, R.D., Poulsen, C.J., Ruffner, C.M., Sheldon, D.G. \& White, T.S. 1999. Storm activity in ancient climates 2 . An analysis using climate simulations and sedimentary structures. Journal of Geophysical Research-Atmospheres, 104 (D22), $27295-27320$.

Ahlberg, A., Olsson, I. \& Simkevicius, P. 2003. Triassic-Jurassic weathering and clay mineral dispersal in basement areas and sedimentary basins of southern Sweden. Sedimentary Geology, 161 (1-2), 15-29.

Aldridge, R.J., Jeppsson, L. \& Dorning, K.J. 1993. Early Silurian oceanic episodes and events. Journal of the Geological Society, 150, 501-513.

Alexandre, A., Meunier, J.D., Llorens, E., Hill, S.M. \& Savin, S.M. 2004. Methodological improvements for investigating silcrete formation: petrography, FT-IR and oxygen isotope ratio of silcrete quartz cement, Lake Eyre Basin (Australia). Chemical Geology, 211 (3-4), 261-274.

Algeo, T.J., Schwark, L. \& Hower, J.C. 2004. High-resolution geochemistry and sequence stratigraphy of the Hushpuckney Shale (Swope Formation, eastern Kansas): implications for climato-environmental dynamics of the Late Pennsylvanian Midcontinent Seaway. Chemical Geology, 206 (3-4), 259-288.

Allen, J.R.L. 1993. Palaeowind: geological criteria for direction and strength. Philosophical Transactions of the Royal Society of London Series B-Biological Sciences, 341 (1297), 235-242.

Allen, J.R.L. 1996. Windblown trees as a palaeoclimate indicator: The character and role of gusts. Palaeogeography Palaeoclimatology Palaeoecology, 121 (1-2), 1-12.

Alley, N.F. \& Frakes, L.A. 2003. First known Cretaceous glaciation: Livingston Tillite Member of the Cadna-owie Formation, South Australia. Australian Journal of Earth Sciences, 50 (2), 139-144. 
Alonso-Zarza, A.M. 2003. Palaeoenvironmental significance of palustrine carbonates and calcretes in the geological record. Earth-Science Reviews, 60 (3-4), 261-298.

Alyea, F.N. 1972. Numerical simulation of an ice age paleoclimate. [Ph.D. thesis]: Fort Collins, Colorado State University.

Andersson, C. 1997. Transfer function vs. modern analog technique for estimating Pliocene sea-surface temperatures based on planktic foraminiferal data, western equatorial Pacific Ocean. Journal of Foraminiferal Research, 27 (2), 123-132.

Andersson, T., Forman, S.L., Ingolfsson, O. \& Manley, W.F. 2000. Stratigraphic and morphologic constraints on the Weichselian glacial history of northern Prins Karls Forland, western Svalbard. Geografiska Annaler Series A-Physical Geography, 82A (4), 455-470.

Andrews, P., Lord, J.M. \& Evans, E.M.N. 1979. Patterns of ecological diversity in fossil and modern mammalian faunas. Biological Journal of the Linnean Society, 11 (2), 177205.

Arrhenius, S. 1896. On the influence of carbonic acid in the air upon the temperature of the ground. Philosophical Magazine Series 5, 4 (251), 237-276.

Averyt, K.B. \& Paytan, A. 2004. A comparison of multiple proxies for export production in the equatorial Pacific. Paleoceanography, 19 (4).

Azmy, K., Veizer, J., Bassett, M.G. \& Copper, P. 1998. Oxygen and carbon isotopic composition of Silurian brachiopods: Implications for coeval seawater and glaciations. Geological Society of America Bulletin, 110 (11), 1499-1512.

Badr, O., Probert, S.D. \& Ocallaghan, P.W. 1992. Methane - a Greenhouse Gas in the Earths Atmosphere. Applied Energy, 41 (2), 95-113.

Baghai, N.L. \& Jorstad, R.B. 1995. Paleontology, paleoclimatology and paleoecology of the Late Middle Miocene Musselshell Creek flora, Clearwater County, Idaho: a preliminary study of a new fossil flora. Palaios, 10 (5), 424-436.

Bailey, I.W. \& Sinnott, E.W. 1916. The climatic distribution of certain types of angiosperm leaves. American Journal of Botany, 3 (1), 24-39.

Bailey, T.R., Rosenthal, Y., McArthur, J.M., van de Schootbrugge, B. \& Thirlwall, M.F. 2003. Paleoceanographic changes of the Late Pliensbachian-Early Toarcian interval: a possible link to the genesis of an Oceanic Anoxic Event. Earth and Planetary Science Letters, 212 (3-4), 307-320.

Ballantyne, C.K. 1994. Gibbsitic soils on former nunataks: implications for ice sheet reconstruction. Journal of Quaternary Science, 9 (1), 73-80.

Ballantyne, C.K., McCarroll, D. \& Stone, J.O. 2006. Vertical dimensions and age of the Wicklow Mountains ice dome, Eastern Ireland, and implications for the extent of the last Irish Ice Sheet. Quaternary Science Reviews, 25 (17-18), 2048-2058.

Bard, E. 2001. Comparison of alkenone estimates with other paleotemperature proxies. Geochemistry Geophysics Geosystems, 2.

Barker, S., Higgins, J.A. \& Elderfield, H. 2003. The future of the carbon cycle: review, calcification response, ballast and feedback on atmospheric CO2. Philosophical Transactions of the Royal Society of London Series a-Mathematical Physical and Engineering Sciences, 361 (1810), 1977-1998.

Barnes, C.R. 2004. Was there an Ordovician superplume? In: Webby, B.D., Droser, M.L., Paris, F. \& Percival, I.G. (eds) The Great Ordovician Biodiversification Event. Columbia University Press, New York, 77-80.

Barreda, V. \& Palamarczuk, S. 2000. Palynostratigraphy of Late Oligocene-Miocene deposits in the southern San Jorge gulf area, Santa Cruz Province, Argentina. Ameghiniana, 37 (1), 103-118. 
Barreiro, M., Philander, G., Pacanowski, R. \& Fedorov, A. 2006. Simulations of warm tropical conditions with application to middle Pliocene atmospheres. Climate Dynamics, 26 (4), 349-365.

Barrick, R.E., Fischer, A.G. \& Showers, W.J. 1999. Oxygen isotopes from turtle bone: Applications for terrestrial paleoclimates? Palaios, 14 (2), 186-191.

Barron, E.J. 1993. Book Review: Climate Modes of the Phanerozoic - Frakes, L.A, Francis, J.E, Syktus, J.I. Nature, 365 (6441), 26-26.

Barron, E.J., Sloan, J.L. \& Harrison, C.G.A. 1980. Potential significance of land-sea distribution and surface albedo variations as a climatic forcing factor: $180 \mathrm{My}$ to the present. Palaeogeography Palaeoclimatology Palaeoecology, 30 (1-2), 17-40.

Barron, E.J., Thompson, S.L. \& Schneider, S.H. 1981. An ice-free Cretaceous: results from climate model simulations. Science, 212 (4494), 501-508.

Bartoli, G., Sarnthein, M., Weinelt, M., Erlenkeuser, H., Garbe-Schonberg, D. \& Lea, D.W. 2005. Final closure of Panama and the onset of northern hemisphere glaciation. Earth and Planetary Science Letters, 237 (1-2), 33-44.

Beard, B.L., Johnson, C.M., Cox, L., Sun, H., Nealson, K.H. \& Aguilar, C. 1999. Iron isotope biosignatures. Science, 285 (5435), 1889-1892.

Beerling, D.J. 1999. Quantitative estimates of changes in marine and terrestrial primary productivity over the past 300 million years. Proceedings of the Royal Society of London Series B-Biological Sciences, 266 (1431), 1821-1827.

Beerling, D.J., Lake, J.A., Berner, R.A., Hickey, L.J., Taylor, D.W. \& Royer, D.L. 2002. Carbon isotope evidence implying high $\mathrm{O}-2 / \mathrm{CO} 2$ ratios in the Permo-Carboniferous atmosphere. Geochimica et Cosmochimica Acta, 66 (21), 3757-3767.

Belousova, E.A., Griffin, W.L., Shee, S.R., Jackson, S.E. \& O'Reilly, S.Y. 2001. Two age populations of zircons from the Timber Creek kimberlites, Northern Territory, as determined by laser-ablation ICP-MS analysis. Australian Journal of Earth Sciences, 48 (5), 757-765.

Belt, S.T., Massé, G., Rowland, S.J., LeBlanc, B., Poulin, M. \& Michel, C. in press. A novel chemical fossil of palaeo sea ice: IP25. Organic Geochemistry

Belt, S.T., Masse, G., Rowland, S.J. \& Rohmer, M. 2006. Highly branched isoprenoid alcohols and epoxides in the diatom Haslea ostrearia Simonsen. Organic Geochemistry, 37 (2), 133-145.

Bennett, M.R. \& Doyle, P. 1996. Global cooling inferred from dropstones in the Cretaceous: Fact or wishful thinking? Terra Nova, 8 (2), 182-185.

Bentaleb, I., Langlois, C., Martin, C., Iacumin, P., Carre, M., Antoine, P.O., Duranthon, F., Moussa, I., Jaeger, J.J., Barrett, N. \& Kandorp, R. 2006. Rhinocerotid tooth enamel O-18/O-16 variability between 23 and $12 \mathrm{Ma}$ in southwestern France. Comptes Rendus Geoscience, 338 (3), 172-179.

Berger, A. \& Loutre, M.F. 2004. Astronomical theory of climate change. Journal De Physique Iv, 121, 1-35.

Bergman, N.M., Lenton, T.M. \& Watson, A.J. 2004. COPSE: A new model of biogeochemical cycling over Phanerozoic time. American Journal of Science, 304 (5), 397-437.

Berner, R.A. 1998. The carbon cycle and CO2 over Phanerozoic time: the role of land plants. Philosophical Transactions of the Royal Society of London Series B-Biological Sciences, 353 (1365), 75-81.

Berner, R.A. 1999. Atmospheric oxygen over Phanerozoic time. Proceedings of the National Academy of Sciences, 96 (20), 10955-10957.

Berner, R.A. 2001. Modeling atmospheric $\mathrm{O}_{2}$ over Phanerozoic time. Geochimica et Cosmochimica Acta, 65 (5), 685-694. 
Berner, R.A. 2003a. The long-term carbon cycle, fossil fuels and atmospheric composition. Nature, 426 (6964), 323-326, 10.1038/nature02131.

Berner, R.A. 2003b. The rise of trees and their effects on Paleozoic atmospheric CO2 and O2. Comptes Rendus Geoscience, 335 (16), 1173-1177.

Berner, R.A. 2004. A model for calcium, magnesium and sulfate in seawater over Phanerozoic time. American Journal of Science, 304 (5), 438-453.

Berner, R.A. 2005. The carbon and sulfur cycles and atmospheric oxygen from middle Permian to middle Triassic. Geochimica et Cosmochimica Acta, 69 (13), 3211-3217.

Berner, R.A. \& Barron, E.J. 1984. Factors affecting atmospheric $\mathrm{CO}_{2}$ and temperature over the past 100 Million years. American Journal of Science, 284 (10), 1183-1192.

Berner, R.A., Beerling, D.J., Dudley, R., Robinson, J.M. \& Wildman, R.A. 2003. Phanerozoic atmospheric oxygen. Annual Review of Earth and Planetary Sciences, 31, 105-134.

Berner, R.A. \& Canfield, D.E. 1989. A new model for atmospheric oxygen over Phanerozoic time. American Journal of Science, 289, 333-361.

Berner, R.A. \& Kothavala, Z. 2001. GEOCARB III: A revised model of atmospheric $\mathrm{CO}_{2}$ over Phanerozoic time. American Journal of Science, 301 (2), 182-204.

Berner, R.A., Petsch, S.T., Lake, J.A., Beerling, D.J., Popp, B.N., Lane, R.S., Laws, E.A., Westley, M.B., Cassar, N., Woodward, F.I. \& Quick, W.P. 2000. Isotope fractionation and atmospheric oxygen: implications for Phanerozoic $\mathrm{O}_{2}$ evolution. Science, 287, $1630-1633$.

Bice, K.L., Birgel, D., Meyers, P.A., Dahl, K.A., Hinrichs, K.U. \& Norris, R.D. 2006. A multiple proxy and model study of Cretaceous upper ocean temperatures and atmospheric $\mathrm{CO} 2$ concentrations. Paleoceanography, 21 (2).

Bice, K.L. \& Norris, R.D. 2002. Possible atmospheric CO2 extremes of the Middle Cretaceous (late Albian-Turonian). Paleoceanography, 17 (4).

Birks, H. 1981. The use of pollen analysis in the reconstruction of past climates: a review. In: Wigley, T.M.L., Ingram, M.J. \& Farmer, G. (eds) Climate and History. Cambridge University Press, Cambridge, 111-138.

Blair, T.C. 1999. Sedimentology of the debris flow dominated Warm Spring Canyon alluvial fan, Death Valley, California. Sedimentology, 46 (5), 941-965.

Blanz, T., Emeis, K.C. \& Siegel, H. 2005. Controls on alkenone unsaturation ratios along the salinity gradient between the open ocean and the Baltic Sea. Geochimica et Cosmochimica Acta, 69 (14), 3589-3600.

Boger, S.D. \& Miller, J.M. 2004. Terminal suturing of Gondwana and the onset of the RossDelamerian Orogeny: the cause and effect of an Early Cambrian reconfiguration of plate motions. Earth and Planetary Science Letters, 219 (1-2), 35-48.

Bonifacio, E., Santoni, S., Celi, L. \& Zanini, E. 2006. Spodosol-Histosol evolution in the Krkonose National Park (CZ). Geoderma, 131 (1-2), 237-250.

Boucot, A.J. \& Gray, J. 2001. A critique of Phanerozoic climatic models involving changes in the $\mathrm{CO} 2$ content of the atmosphere. Earth-Science Reviews, 56 (1-4), 1-159.

Boyle, E.A. 1988. Cadmium: chemical tracer of deepwater paleoceanography. Paleoceanography, 3, 471-489.

Braga, J.C. \& Aguirre, J. 2001. Coralline algal assemblages in upper Neogene reef and temperate carbonates in Southern Spain. Palaeogeography Palaeoclimatology Palaeoecology, 175 (1-4), 27-41.

Brenchley, P.J., Carden, G.A., Hints, L., Kaljo, D., Marshall, J.D., Martma, T., Meidla, T. \& Nolvak, J. 2003. High-resolution stable isotope stratigraphy of Upper Ordovician sequences: Constraints on the timing of bioevents and environmental changes 
associated with mass extinction and glaciation. Geological Society of America Bulletin, 115 (1), 89-104.

Brentnall, S.J., Beerling, D.J., Osborne, C.P., Harland, W.M., Francis, J.E., Valdes, P.J. \& Wittig, V.E. 2005. Climatic and ecological determinants of leaf lifespan in polar forests of the high CO2 Cretaceous 'greenhouse' world. Global Change Biology, 11 (12), 2177-2195.

Briffa, K.R., Jones, P.D., Schweingruber, F.H. \& Osborn, T.J. 1998. Influence of volcanic eruptions on Northern Hemisphere summer temperature over the past 600 years. Nature, 393 (6684), 450-455.

Briffa, K.R., Osborn, T.J. \& Schweingruber, F.H. 2004. Large-scale temperature inferences from tree rings: a review. Global and Planetary Change, 40 (1-2), 11-26.

Brinkhuis, H., Schouten, S., Collinson, M.E.and 36 others 2006. Episodic fresh surface waters in the Eocene Arctic Ocean. Nature, 441, 606-609, 10.1038/nature04692.

Brison, A.L., Philippe, M. \& Thevenard, F. 2001. Are Mesozoic wood growth rings climateinduced? Paleobiology, 27 (3), 531-538.

Broecker, W.S. \& Clark, E. 2001. Reevaluation of the CaCO3 size index paleocarbonate ion proxy. Paleoceanography, 16 (6), 669-671.

Brouwers, E.M., Jorgensen, N.O. \& Cronin, T.M. 1991. Climatic significance of the ostracode fauna from the Pliocene Kap Kobenhavn Formation, north Greenland. Micropaleontology, 37 (3), 245-267.

Bruckschen, P., Oesmann, S. \& Veizer, J. 1999. Isotope stratigraphy of the European Carboniferous: proxy signals for ocean chemistry, climate and tectonics. Chemical Geology, 161 (1-3), 127-163.

Buggisch, W. 1991. The global Frasnian-Famennian Kellwasser Event. Geologische Rundschau, 80 (1), 49-72.

Caldeira, K. 2006. Forests, climate, and silicate rock weathering. Journal of Geochemical Exploration, 88 (1-3), 419-422.

Caldeira, K. \& Rampino, M.R. 1991. The mid-Cretaceous super plume, carbon dioxide, and global warming. Geophysical Research Letters, 18 (6), 987-990.

Caplan, M.L. \& Bustin, R.M. 1999. Devonian-Carboniferous Hangenberg mass extinction event, widespread organic-rich mudrock and anoxia: causes and consequences. Palaeogeography Palaeoclimatology Palaeoecology, 148 (4), 187-207.

Chamberlin, T.C. 1897. A group of hypotheses bearing on climatic changes. Journal of Geology, 5, 653-683.

Chamberlin, T.C. 1899. An attempt to frame a working hypothesis of the cause of glacial periods on an atmospheric basis. Journal of Geology, 7, 545-584, 667-685, 751-787.

Chamberlin, T.C. 1906. On a possible reversal of deep-sea circulation and its influence on geologic climates. Proceedings of the American Philosophical Society, 45 (182), 3343.

Chamley, H. 1989. Clay Sedimentology. Springer, Berlin.

Chamley, H. 1998. Clay mineral sedimentation in the ocean. In: Paquet, H. \& Clauer, N. (eds) Soils and Sediments, Mineralogy and Geochemistry. Springer, Heidelberg, 269302.

Chandler, M.A., Rind, D. \& Ruedy, R. 1992. Pangaean climate during the Early Jurassic: GCM simulations and the sedimentary record of paleoclimate. Geological Society of America Bulletin, 104 (5), 543-559.

Chase, Z., Anderson, R.F., Fleisher, M.Q. \& Kubik, P. 2002. The influence of particle composition on scavenging of $\mathrm{Th}, \mathrm{Pa}$ and $\mathrm{Be}$ in the ocean. Earth and Planetary Science Letters, 204 (1-2), 215-229, 10.1016/S0012-821X(02)00984-6. 
Chaudhuri, A.K. 2005. Climbing ripple structure and associated storm-lamination from a Proterozoic carbonate platform succession: Their environmental and petrogenetic significance. Journal of Earth System Science, 114 (3), 199-209.

Chumakov, N.M. \& Frakes, L.A. 1997. Mode of origin of dispersed clasts in Jurassic shales; Southern part of the Yana-Kolyma fold belt, North East Asia. Palaeogeography Palaeoclimatology Palaeoecology, 128 (1-4), 77-85.

Cisternas, M., Atwater, B.F., Torrejon, F., Sawai, Y., Machuca, G., Lagos, M., Eipert, A., Youlton, C., Salgado, I., Kamataki, T., Shishikura, M., Rajendran, C.P., Malik, J.K., Rizal, Y. \& Husni, M. 2005. Predecessors of the giant 1960 Chile earthquake. Nature, 437 (7057), 404-407.

Clemens, S.C. 1998. Dust response to seasonal atmospheric forcing: Proxy evaluation and calibration. Paleoceanography, 13 (5), 471-490.

CLIMAP 1981. Seasonal reconstruction of the Earth's surface at the last glacial maximum. Map and Chart Series MC-36.1-18. Geological Society of America.

Cohen, A.S., Coe, A.L., Harding, S.M. \& Schwark, L. 2004. Osmium isotope evidence for the regulation of atmospheric $\mathrm{CO}_{2}$ by continental weathering. Geology, 32 (2), 157160.

Condie, K.C. 2002. The supercontinent cycle: are there two patterns of cyclicity? Journal of African Earth Sciences, 35 (2), 179-183.

Constantine, A., Chinsamy, A., Vickers-Rich, P. \& Rich, T.H. 1998. Periglacial environments and polar dinosaurs. South African Journal of Science, 94 (3), 137-141.

Cook, P.J. 1992. Phosphogenesis around the Proterozoic-Phanerozoic transition. Journal of the Geological Society, 149, 615-620.

Coram, R.A. \& Jarzembowski, E.A. 2002. Diversity and ecology of fossil insects in the Dorset Purbeck succession, southern England Life and Environments in Purbeck Times. Special Papers in Palaeontology Series. Palaeontological Association, Aberystwyth, 68, 257-268.

Cowan, C.A., Fox, D.L., Runkel, A.C. \& Saltzman, M.R. 2005. Terrestrial-marine carbon cycle coupling in similar to 500-m.y.-old phosphatic brachiopods. Geology, 33 (8), 661-664.

Creber, G.T. \& Chaloner, W.G. 1985. Tree growth in the Mesozoic and early Tertiary and the reconstruction of paleoclimates. Palaeogeography Palaeoclimatology Palaeoecology, $52(1-2), 35-59$.

Croll, J. 1867. On the change in the obliquity of the ecliptic, its influence on the climate of the polar regions and the level of the sea. Philosophical Magazine Series 4, 33, 426445.

Crosta, X., Pichon, J.J. \& Burckle, L.H. 1998. Application of modern analog technique to marine Antarctic diatoms: Reconstruction of maximum sea-ice extent at the Last Glacial Maximum. Paleoceanography, 13 (3), 284-297.

Crowell, J.C. 1999. Pre-Mesozoic ice ages: their bearing on understanding the climate system, Geological Society of America Memoirs, Volume 145, 112.

Crowley, T.J. \& Baum, S.K. 1992. Modeling Late Paleozoic glaciation. Geology, 20 (6), 507-510.

Crowley, T.J. \& North, G.R. 1991. Paleoclimatology. Oxford University Press, Oxford.

Crowley, T.J., Yip, K.J.J. \& Baum, S.K. 1993. Milankovitch Cycles and Carboniferous Climate. Geophysical Research Letters, 20 (12), 1175-1178.

Cubasch, U., Santer, B.D., Hellbach, A., Hegerl, G., Hock, H., Maierreimer, E., Mikolajewicz, U., Stossel, A. \& Voss, R. 1994. Monte-Carlo Climate-Change Forecasts with a Global Coupled Ocean-Atmosphere Model. Climate Dynamics, 10 (1-2), 1-19. 
Cubasch, U., Voss, R., Hegerl, G.C., Waszkewitz, J. \& Crowley, T.J. 1997. Simulation of the influence of solar radiation variations on the global climate with an ocean-atmosphere general circulation model. Climate Dynamics, 13 (11), 757-767.

Cullen, J.T. \& Sherrell, R.M. 2005. Effects of dissolved carbon dioxide, zinc, and manganese on the cadmium to phosphorus ratio in natural phytoplankton assemblages. Limnology and Oceanography, 50 (4), 1193-1204.

Darwin, C.R. 1842. Notes on the effects produced by ancient glaciers of Caernarvonshire, and on the boulders transported by floating ice. London, Edinburgh, and Dublin Philosophical Magazine and Journal of Science, 21, 180-188.

David, K., Frank, M., O’Nions, R.K., Belshaw, N.S. \& Arden, J.W. 2001. The Hf isotope composition of global seawater and the evolution of Hf isotopes in the deep Pacific Ocean from Fe-Mn crusts. Chemical Geology, 178, 23-42.

Davis, W.J. \& Miller, A.R. 2001. A Late Triassic Rb-Sr phlogopite isochron age for a kimberlite dyke from the Rankin Inlet area, Nunavut. Radiogenic Age and Isotope Studies: Report 14, Current Research 2001-F3.

De La Rocha, C.L., Brzezinski, M.A., DeNiro, M.J. \& Shemesh, A. 1998. Silicon-isotope composition of diatoms as an indicator of past oceanic change. Nature, 395 (6703), 680-683.

De Man, E. \& Van Simaeys, S. 2004. Late Oligocene Warming Event in the southern North Sea Basin: benthic foraminifera as paleotemperature proxies. Netherlands Journal of Geosciences-Geologie En Mijnbouw, 83 (3), 227-239.

de Villiers, S. 2005. Foraminiferal shell-weight evidence for sedimentary calcite dissolution above the lysocline. Deep-Sea Research Part I-Oceanographic Research Papers, 52 (5), 671-680.

Demicco, R.V., Lowenstein, T.K. \& Hardie, L.A. 2003. Atmospheric pCO(2) since $60 \mathrm{Ma}$ from records of seawater $\mathrm{pH}$, calcium, and primary carbonate mineralogy. Geology, 31 (9), 793-796.

Denton, G.H. \& Armstrong, R.L. 1969. Miocene-Pliocene glaciations in southern Alaska. American Journal of Science, 267, 1121-1142.

Dessert, C., Dupre, B., Francois, L.M., Schott, J., Gaillardet, J., Chakrapani, G. \& Bajpai, S. 2001. Erosion of Deccan Traps determined by river geochemistry: impact on the global climate and the ${ }^{87} \mathrm{Sr} /{ }^{86} \mathrm{Sr}$ ratio of seawater. Earth and Planetary Science Letters, 188 (3-4), 459-474.

Devilliers, S., Shen, G.T. \& Nelson, B.K. 1994. The Sr/Ca temperature relationship in coralline aragonite: influence of variability in $(\mathrm{Sr} / \mathrm{Ca})$ seawater and skeletal growth parameters. Geochimica et Cosmochimica Acta, 58 (1), 197-208.

Dewey, J.F. 2005. Orogeny can be very short. Proceedings of the National Academy of Sciences of the United States of America, 102 (43), 15286-15293.

Dickens, G.R. 2000. Methane oxidation during the Late Palaeocene Thermal Maximum. Bulletin De La Societe Geologique De France, 171 (1), 37-49.

Dickinson, R.E. 1989. Uncertainties of estimates of climatic change: a review. Climatic Change, 15 (1-2), 5-13.

Dickinson, W.R. 2004. Evolution of the North American Cordillera. Annual Review of Earth and Planetary Sciences, 32, 13-45.

Doblas, M., Oyarzun, R., Lopez-Ruiz, J., Cebria, J.M., Youbi, N., Mahecha, V., Lago, M., Pocovi, A. \& Cabanis, B. 1998. Permo-Carboniferous volcanism in Europe and northwest Africa: a superplume exhaust valve in the centre of Pangaea? Journal of African Earth Sciences, 26 (1), 89-99.

Dodonov, A.E. \& Baiguzina, L.L. 1995. Loess stratigraphy of Central Asia: Palaeoclimatic and palaeoenvironmental aspects. Quaternary Science Reviews, 14 (7-8), 707-720. 
Doran, P.T., Fritsen, C.H., McKay, C.P., Priscu, J.C. \& Adams, E.E. 2003. Formation and character of an ancient 19-m ice cover and underlying trapped brine in an "ice-sealed" east Antarctic lake. Proceedings of the National Academy of Sciences of the United States of America, 100 (1), 26-31.

Driese, S.G., Nordt, L.C., Lynn, W.C., Stiles, C.A., Mora, C.I. \& Wilding, L.P. 2005. Distinguishing climate in the soil record using chemical trends in a vertisol climosequence from the Texas Coast Prairie, and application to interpreting paleozoic paleosols in the Appalachian basin, USA. Journal of Sedimentary Research, 75 (3), 339-349.

Driese, S.G. \& Ober, E.G. 2005. Paleopedologic and paleohydrologic records of precipitation seasonality from early Pennsylvanian "underclay" Paleosols, USA. Journal of Sedimentary Research, 75 (6), 997-1010.

Dromart, G., Garcia, J.P., Picard, S., Atrops, F., Lecuyer, C. \& Sheppard, S.M.F. 2003. Ice age at the Middle-Late Jurassic transition? Earth and Planetary Science Letters, 213 (3-4), 205-220.

Duncan, R.A. \& Helgason, J. 1998. Precise dating of the Holmatindur cooling event in eastern Iceland: Evidence for mid-Miocene bipolar glaciation. Journal of Geophysical Research-Solid Earth, 103 (B6), 12,397-12,404.

Dutton, J.F. \& Barron, E.J. 2000. Intra-annual and interannual ensemble forcing of a regional climate model. Journal of Geophysical Research-Atmospheres, 105 (D24), 2952329538.

Edinger, E.N., Copper, P., Risk, M.J. \& Atmojo, W. 2002. Oceanography and reefs of recent and Paleozoic tropical epeiric seas. Facies, 47, 127-149.

Edwards, D. 1984. Fire regimes in the biomes of South Africa. In: Booysen, P.D.V. \& Tainton, N.M. (eds) Ecological effects of fire. Ecological Studies, 48, 19-38.

Edwards, D. 1998. Climate signals in Palaeozoic land plants. Philosophical Transactions of the Royal Society of London Series B-Biological Sciences, 353 (1365), 141-156.

Edwards, R.L., Cheng, H., Murrell, M.T. \& Goldstein, S.J. 1997. Protactinium-231 dating of carbonates by thermal ionization mass spectrometry: implications for Quaternary climate change. Science, 276 (5313), 782-786, 10.1126/science.276.5313.782.

Ehrmann, W., Setti, M. \& Marinoni, L. 2005. Clay minerals in Cenozoic sediments off Cape Roberts (McMurdo Sound, Antarctica) reveal palaeoclimatic history. Palaeogeography Palaeoclimatology Palaeoecology, 229 (3), 187-211.

Elderfield, H. 2002. Foraminiferal $\mathrm{Mg} / \mathrm{Ca}$ paleothermometry: expected advances and unexpected consequences. Geochimica et Cosmochimica Acta, 66, A213.

Elderfield, H. \& Rickaby, R.E.M. 2000. Oceanic Cd/P ratio and nutrient utilization in the glacial Southern Ocean. Nature, 405 (6784), 305-310.

Elderfield, H., Vautravers, M. \& Cooper, M. 2002. The relationship between shell size and $\mathrm{Mg} / \mathrm{Ca}, \mathrm{Sr} / \mathrm{Ca}$, delta $\mathrm{O}-18$, and delta $\mathrm{C}-13$ of species of planktonic foraminifera. Geochemistry Geophysics Geosystems, 3.

Eldholm, O. \& Grue, K. 1994. North Atlantic volcanic margins: dimensions and production rates. Journal of Geophysical Research-Solid Earth, 99 (B2), 2955-2968.

Ellwood, M.J., Kelly, M., Nodder, S.D. \& Carter, L. 2004. Zinc/silicon ratios of sponges: A proxy for carbon export to the seafloor. Geophysical Research Letters, 31 (12).

Elorza, J., Garcia-Garmilla, F. \& Jagt, J.W.M. 1996. Diagenesis-related differences in isotopic and elemental composition of late Campanian and early Maastrichtian inoceramids and belemnites from NE Belgium: Palaeoenvironmental implications. Geologie en Mijnbouw, 75 (4), 349-360.

Elshahed, M.S., Najar, F.Z., Roe, B.A., Oren, A., Dewers, T.A. \& Krumholz, L.R. 2004. Survey of archaeal diversity reveals an abundance of halophilic Archaea in a low-salt, 
sulfide- and sulfur-rich spring. Applied and Environmental Microbiology, 70 (4), 2230-2239.

Emanuel, K. 2002. A simple model of multiple climate regimes. Journal of Geophysical Research-Atmospheres, 107 (D9).

Emiliani, C. 1955. Pleistocene temperatures. Journal of Geology, 63, 538-578.

Epstein, S., Buchsbaum, R., Lowenstam, H.A. \& Urey, H.C. 1953. Revised carbonate-water isotopic temperature scale. Geological Society of America Bulletin, 64, 1315-1325.

Erba, E. 2006. The first 150 million years history of calcareous nannoplankton: Biospheregeosphere interactions. Palaeogeography Palaeoclimatology Palaeoecology, 232 (24), 237-250.

Ernst, R.E. \& Buchan, K.L. 2001. Large mafic magmatic events through time and links to mantle plume heads. In: Ernst, R.E. \& Buchan, K.L. (eds) Mantle Plumes: Their Identification Through Time, 352, 483-575.

Ernst, R.E., Buchan, K.L. \& Campbell, I.H. 2005. Frontiers in Large Igneous Province research. Lithos, 79, 271-297, 10.1016/j.lithos.2004.09.004.

Evans, D.A.D. 2000. Stratigraphic, geochronological, and paleomagnetic constraints upon the neoproterozoic climatic paradox. American Journal of Science, 300 (5), 347-433.

Evans, D.A.D. 2003. A fundamental Precambrian-Phanerozoic shift in earth's glacial style? Tectonophysics, 375 (1-4), 353-385.

Eyles, N. 1993. Earths glacial record and its tectonic setting. Earth-Science Reviews, 35 (12), 1-248.

Eyles, N., Mory, A.J. \& Backhouse, J. 2002. Carboniferous-Permian palynostratigraphy of west Australian marine rift basins: resolving tectonic and eustatic controls during Gondwanan glaciations. Palaeogeography Palaeoclimatology Palaeoecology, 184 (34), 305-319.

Eyles, N., Mory, A.J. \& Eyles, C.H. 2006. 50-million-year-long record of glacial to postglacial marine environments preserved in a Carboniferous-Lower Permian graben, Northern Perth Basin, Western Australia. Journal of Sedimentary Research, 76 (3-4), 618-632.

Faegri, K. \& Iverson, J. 1950. Textbook of Modern Pollen Analysis. Ejnar Munksgaard, Copenhagen.

Falcon-Lang, H.J. 1999. The Early Carboniferous (Courceyan-Arundian) monsoonal climate of the British Isles: evidence from growth rings in fossil woods. Geological Magazine, 136 (2), 177-187.

Falkowski, P.G. 1997. Evolution of the nitrogen cycle and its influence on the biological sequestration of $\mathrm{CO}_{2}$ in the ocean. Nature, 387, 272-275, 10.1038/387272a0.

Farley, K.A. \& Eltgroth, S.F. 2003. An alternative age model for the Paleocene-Eocene thermal maximum using extraterrestrial ${ }^{3} \mathrm{He}$. Earth and Planetary Science Letters, 208 (3-4), 135-148.

Fauquette, S. \& Bertini, A. 2003. Quantification of the northern Italy Pliocene climate from pollen data: evidence for a very peculiar climate pattern. Boreas, 32 (2), 361-369.

Felzer, B.A. \& Thompson, S.L. 2001. Evaluation of a regional climate model for paleoclimate applications in the Arctic. Journal of Geophysical ResearchAtmospheres, 106 (D21), 27407-27424.

Fernandez, M.H. \& Pelaez-Campomanes, P. 2005. Quantitative palaeoclimatic inference based on terrestrial mammal faunas. Global Ecology and Biogeography, 14 (1), 3956.

Finkelstein, D.B., Pratt, L.M., Curtin, T.M. \& Brassell, S.C. 2005. Wildfires and seasonal aridity recorded in Late Cretaceous strata from south-eastern Arizona, USA. Sedimentology, 52 (3), 587-599. 
Flower, B.P. 1999. Cenozoic deep-sea temperatures and polar glaciation: the oxygen isotope record. Terra Antartica Reports, 3, 27-42.

Fortey, N.J., Merriman, R.J. \& Huff, W.D. 1996. Silurian and late Ordovician K-bentonites as a record of late Caledonian volcanism in the British Isles. Transactions of the Royal Society of Edinburgh-Earth Sciences, 86, 167-180.

Foukal, P., Frohlich, C., Spruit, H. \& Wigley, T.M.L. 2006. Variations in solar luminosity and their effect on the Earth's climate. Nature, 443 (7108), 161-166.

Frakes, L.A. 1979. Climates through geologic time. Elsevier, Amsterdam.

Frakes, L.A., Francis, J.E. \& Syktus, J.I. 1992. Climate modes of the Phanerozoic - The history of the Earth's climate over the past 600 million years. Cambridge University Press, Cambridge.

Francis, J.E. 1986. Growth rings in Cretaceous and Tertiary wood from Antarctica and their paleoclimatic implications. Palaeontology, 29, 665-684.

Francis, J.E. \& Poole, I. 2002. Cretaceous and early Tertiary climates of Antarctica: evidence from fossil wood. Palaeogeography Palaeoclimatology Palaeoecology, 182 (1-2), 47-64.

Francois, L.M. \& Gerard, J.C. 1986. A Numerical-Model of the Evolution of Ocean Sulfate and Sedimentary Sulfur During the Last 800 Million Years. Geochimica et Cosmochimica Acta, 50 (10), 2289-2302.

Francois, L.M. \& Walker, J.C.G. 1992. Modeling the Phanerozoic carbon cycle and climate: constraints from the ${ }^{87} \mathrm{Sr}^{86} \mathrm{Sr}$ isotopic ratio of seawater. American Journal of Science, 292 (2), 81-135.

Francois, R., Altabet, M.A., Yu, E.-F., Sigman, D.M., Bacon, M.P., Frank, M., Bohrmann, G., Bareille, G. \& Labeyrie, L.D. 1997. Contribution of Southern Ocean surface-water stratification to low atmospheric $\mathrm{CO} 2$ concentrations during the last glacial period. Nature, 389, 929-935.

Freiwald, A., Henrich, R. \& Pätzold, J. 1997. Anatomy of a deep-water coral reef mound from Stjernsund, West Finnmark, northern Norway. In: James, N.P. \& Clarke, J.A.D. (eds) Cool-water carbonates. SEPM Special Volume. SEPM, Tulsa Oklahoma, 56, 741-762.

Freiwald, A. \& Wilson, J.B. 1998. Taphonomy of modern deep, cold-temperate water coral reefs. Historical Biology, 13, 37-52.

Friedman, M., Tarduno, J.A. \& Brinkman, D.B. 2003. Fossil fishes from the high Canadian Arctic: further palaeobiological evidence for extreme climatic warmth during the Late Cretaceous (Turonian-Coniacian). Cretaceous Research, 24 (6), 615-632.

Friedrich, O., Herrle, J.O. \& Hemleben, C. 2005. Climatic changes in the Late CampanianEarly Maastrichtian: Micropaleontological and stable isotopic evidence from an epicontinental sea. Journal of Foraminiferal Research, 35 (3), 228-247.

Friedrich, O., Schmiedl, G. \& Erlenkeuser, H. 2006. Stable isotope composition of Late Cretaceous benthic foraminifera from the southern South Atlantic: Biological and environmental effects. Marine Micropaleontology, 58 (2), 135-157.

Fritts, H.C. 1976. Tree rings and climate. Academic Press, London.

Garrels, R.M. \& Lerman, A. 1984. Coupling of the sedimentary sulfur and carbon cycles: an improved model. American Journal of Science, 284 (9), 989-1007.

Gates, W.L. 1974. Numerical simulation of Ice Age climate. Transactions-American Geophysical Union, 55 (4), 259-259.

Gates, W.L. 1976. Numerical simulation of Ice Age climate with a global general circulation model. Journal of the Atmospheric Sciences, 33 (10), 1844-1873. 
Gazdzicki, A., Gruszczynski, M., Hoffman, A., Malkowski, K., Marenssi, S.A., Halas, S. \& Tatur, A. 1992. Stable carbon and oxygen isotope record in the Paleogene La Meseta Formation, Seymour Island, Antarctica. Antarctic Science, 4 (4), 461-468.

Genc, S.C. 2004. A Triassic large igneous province in the Pontides, northern Turkey: geochemical data for its tectonic setting. Journal of Asian Earth Sciences, 22 (5), 503-516.

Gersonde, R. \& Zielinski, U. 2000. The reconstruction of late Quaternary Antarctic sea-ice distribution - the use of diatoms as a proxy for sea-ice. Palaeogeography Palaeoclimatology Palaeoecology, 162 (3-4), 263-286.

Gibbs, M.T., Barron, E.J. \& Kump, L.R. 1997. An atmospheric $\mathrm{pCO}_{2}$ threshold for glaciation in the Late Ordovician. Geology, 25 (5), 447-450.

Gifford, R. 1994. The global carbon cycle: a viewpoint on the missing sink. Australian Journal of Plant Physiology, 21 (1), 1-15, 10.1071/PP9940001.

Gingele, F. \& Dahmke, A. 1994. Discrete barite particles and barium as tracers of paleoproductivity in South Atlantic sediments. Paleoceanography, 9 (1), 151-168, 10.1029/93PA02559.

Gingele, F.X. \& Schmieder, F. 2001. Anomalous South Atlantic lithologies confirm global scale of unusual mid-Pleistocene climate excursion. Earth and Planetary Science Letters, 186 (1), 93-101.

Glass, L.M. \& Phillips, D. 2006. The Kalkarindji continental flood basalt province: A new Cambrian large igneous province in Australia with possible links to faunal extinctions. Geology, 34 (6), 461-464, 10.1130/G22122.1.

Glasspool, I. 2000. A major fire event recorded in the mesofossils and petrology of the Late Permian, Lower Whybrow coal seam, Sydney Basin, Australia. Palaeogeography Palaeoclimatology Palaeoecology, 164 (1-4), 357-380.

Glasspool, I.J., Hilton, J., Collinson, M.E., Wang, S.J. \& Li Cheng, S. 2004. Foliar physiognomy in Cathaysian gigantopterids and the potential to track Palaeozoic climates using an extinct plant group. Palaeogeography Palaeoclimatology Palaeoecology, 205 (1-2), 69-110.

Glumac, B. \& Spivak-Bimdorf, M.L. 2002. Stable isotopes of carbon as an invaluable stratigraphic tool: An example from the Cambrian of the northern Appalachians, USA. Geology, 30 (6), 563-566.

Gradstein, F.M., Ogg, J.G., Smith, A.G.and 36 others 2004. A Geologic Time Scale 2004. Cambridge University Press, Cambridge.

Gregory-Wodzicki, K.M. 2000. Relationships between leaf morphology and climate, Bolivia: implications for estimating paleoclimate from fossil floras. Paleobiology, 26 (4), 668688.

Greinert, J. \& Derkachev, A. 2004. Glendonites and methane-derived Mg-calcites in the Sea of Okhotsk, Eastern Siberia: implications of a venting-related ikaite/glendonite formation. Marine Geology, 204 (1-2), 129-144.

Griffin, W.L., Ryan, C.G., Kaminsky, F.V., O’Reilly, S.Y., Natapov, L.M., Win, T.T., Kinny, P.D. \& Ilupin, I.P. 1999. The Siberian lithosphere traverse: mantle terranes and the assembly of the Siberian Craton. Tectonophysics, 310 (1-2), 1-35.

Grimes, S.T., Hooker, J.J., Collinson, M.E. \& Mattey, D.P. 2005. Summer temperatures of late Eocene to early Oligocene freshwaters. Geology, 33 (3), 189-192.

Grimes, S.T., Mattey, D.P., Hooker, J.J. \& Collinson, M.E. 2003. Paleogene paleoclimate reconstruction using oxygen isotopes from land and freshwater organisms: the use of multiple paleoproxies. Geochimica et Cosmochimica Acta, 67 (21), 4033-4047. 
Grzebyk, D., Schofield, O., Vetriani, C. \& Falkowski, P.G. 2003. The Mesozoic radiation of eukaryotic algae: the portable plastid hypothesis. Journal of Phycology, 39 (2), 259267.

Guidry, M.W. \& Mackenzie, F.T. 2000. Apatite weathering and the Phanerozoic phosphorus cycle. Geology, 28 (7), 631-634.

Gunnell, Y. 1998. Passive margin uplifts and their influence on climatic change and weathering patterns of tropical shield regions. Global and Planetary Change, 18 (12), 47-57.

Gussone, N., Eisenhauer, A., Heuser, A., Dietzel, M., Bock, B., Bohm, F., Spero, H.J., Lea, D.W., Bijma, J. \& Nagler, T.F. 2003. Model for kinetic effects on calcium isotope fractionation (delta $\mathrm{Ca}-44)$ in inorganic aragonite and cultured planktonic foraminifera. Geochimica et Cosmochimica Acta, 67 (7), 1375-1382.

Haley, B.A., Klinkhammer, G.P. \& Mix, A.C. 2005. Revisiting the rare earth elements in foraminiferal tests. Earth and Planetary Science Letters, 239 (1-2), 79-97.

Hallam, A. 1985. A review of Mesozoic climates. Journal of the Geological Society, London, 142, 433-445.

Hallam, A. \& Wignall, P.B. 1999. Mass extinctions and sea-level changes. Earth-Science Reviews, 48 (4), 217-250.

Hamilton, S., Shennan, I., Combellick, R., Mulholland, J. \& Noble, C. 2005. Evidence for two great earthquakes at Anchorage, Alaska and implications for multiple great earthquakes through the Holocene. Quaternary Science Reviews, 24 (18-19), 20502068.

Hammond, D.E., McManus, J. \& Berelson, W.M. 2004. Oceanic germanium/silicon ratios: Evaluation of the potential overprint of temperature on weathering signals. Paleoceanography, 19 (2).

Hansen, K.W. \& Wallmann, K. 2003. Cretaceous and Cenozoic evolution of seawater composition, atmospheric $\mathrm{O}_{2}$ and $\mathrm{CO}_{2}$ : A model perspective. American Journal of Science, 303 (2), 94-148.

Hardie, L.A. 1996. Secular variation in seawater chemistry: An explanation for the coupled secular variation in the mineralogies of marine limestones and potash evaporites over the past 600 m.y. Geology, 24 (3), 279-283.

Harrington, G.J. 2004. Structure of the North American vegetation gradient during the late Paleocene/early Eocene warm climate. Evolutionary Ecology Research, 6 (1), 33-48.

Harris, T.M. 1981. Burnt ferns from the English Wealden. Proceedings of the Geologists' Association, 92, 47-58.

Harrison, R.G. \& Stephenson, D.B. 2006. Empirical evidence for a nonlinear effect of galactic cosmic rays on clouds. Proceedings of the Royal Society A-Mathematical Physical and Engineering Sciences, 462 (2068), 1221-1233.

Haug, G.H., Ganopolski, A., Sigman, D.M., Rosell-Mele, A., Swann, G.E.A., Tiedemann, R., Jaccard, S.L., Bollmann, J., Maslin, M.A., Leng, M.J. \& Eglinton, G. 2005. North Pacific seasonality and the glaciation of North America 2.7 million years ago. Nature, 433 (7028), 821-825.

Hausmann, S. \& Kienast, F. 2006. A diatom-inference model for nutrients screened to reduce the influence of background variables: Application to varved sediments of Greifensee and evaluation with measured data. Palaeogeography Palaeoclimatology Palaeoecology, 233 (1-2), 96-112.

Haworth, M., Hesselbo, S.P., McElwain, J.C., Robinson, S.A. \& Brunt, J.W. 2005. MidCretaceous $\mathrm{pCO}_{2}$ based on stomata of the extinct conifer Pseudofrenelopsis (Cheirolepidiaceae). Geology, 33 (9), 749-752.

Hay, W.W. 1996. Tectonics and climate. Geologische Rundschau, 85 (3), 409-437. 
Hay, W.W., DeConto, R.M. \& Wold, C.N. 1997. Climate: Is the past the key to the future? Geologische Rundschau, 86 (2), 471-491.

Hays, J.D., Imbrie, J. \& Shackleton, N.J. 1976. Variations in the Earth's orbit: pacemaker of the ice ages. Science, 194, 1121-1132.

Hays, P.D. \& Grossman, E.L. 1991. Oxygen isotopes in meteoric calcite cements as indicators of continental paleoclimate. Geology, 19 (5), 441-444.

Hayward, B.W. 2001. Global deep-sea extinctions during the Pleistocene ice ages. Geology, 29 (7), 599-602.

Haywood, A.M., Dekens, P., Ravelo, A.C. \& Williams, M. 2005. Warmer tropics during the mid-Pliocene? Evidence from alkenone paleothermometry and a fully coupled oceanatmosphere GCM. Geochemistry Geophysics Geosystems, 6 (3), 1-20, 10.1029/2004GC000799.

Haywood, A.M., Sellwood, B.W. \& Valdes, P.J. 2000. Regional warming: Pliocene (3 Ma) paleoclimate of Europe and the Mediterranean. Geology, 28 (12), 1063-1066.

Haywood, A.M. \& Valdes, P.J. 2004. Modelling Pliocene warmth: contribution of atmosphere, oceans and cryosphere. Earth and Planetary Science Letters, 218 (3-4), 363-377.

Haywood, A.M., Valdes, P.J., Francis, J.E. \& Sellwood, B.W. 2002a. Global middle Pliocene biome reconstruction: A data/model synthesis. Geochemistry Geophysics Geosystems, 3.

Haywood, A.M., Valdes, P.J. \& Markwick, P.J. 2004. Cretaceous (Wealden) climates: a modelling perspective. Cretaceous Research, 25 (3), 303-311.

Haywood, A.M., Valdes, P.J. \& Peck, V.L. in press. A permanent El Niño-like state during the Pliocene? Paleoceanography.

Haywood, A.M., Valdes, P.J., Sellwood, B.W. \& Kaplan, J.O. 2002b. Antarctic climate during the middle Pliocene: model sensitivity to ice sheet variation. Palaeogeography Palaeoclimatology Palaeoecology, 182 (1-2), 93-115.

Heaman, L.M. \& Kjarsgaard, B.A. 2000. Timing of eastern North American kimberlite magmatism: continental extension of the Great Meteor hotspot track? Earth and Planetary Science Letters, 178 (3-4), 253-268.

Heaman, L.M., Kjarsgaard, B.A. \& Creaser, R.A. 2003. The timing of kimberlite magmatism in North America: implications for global kimberlite genesis and diamond exploration. Lithos, 71 (2-4), 153-184.

Heckel, P.H. 1986. Sea-level curve for Pennsylvanian eustatic marine transgressiveregressive depositional cycles along midcontinent outcrop belt, North America. Geology, 14 (4), 330-334.

Heckel, P.H. 1996. Glacial-eustatic base-level climatic model for late Middle to Late Pennsylvanian coal-bed formation in the Appalachian basin. Journal of Sedimentary Research Section B-Stratigraphy and Global Studies, 65 (3), 348-356.

Heilbron, M. \& Machado, N. 2003. Timing of terrane accretion in the NeoproterozoicEopaleozoic Ribeira orogen (se Brazil). Precambrian Research, 125 (1-2), 87-112.

Henderson, G.M. 2002. New oceanic proxies for paleoclimate. Earth and Planetary Science Letters, 203 (1), 1-13.

Hentschke, U. \& Milkert, D. 1996. Power spectrum analyses of storm layers in marine silty sediments: A tool for a paleoclimatic reconstruction? Journal of Coastal Research, 12 (4), 898-906.

Herndl, G.J., Reinthaler, T., Teira, E., van Aken, H., Veth, C., Pernthaler, A. \& Pernthaler, J. 2005. Contribution of Archaea to total prokaryotic production in the deep Atlantic Ocean. Applied and Environmental Microbiology, 71 (5), 2303-2309. 
Herrmann, A.D., Patzkowsky, M.E. \& Pollard, D. 2003. Obliquity forcing with 8-12 times preindustrial levels of atmospheric $\mathrm{pCO}(2)$ during the Late Ordovician glaciation. Geology, 31 (6), 485-488.

Hesselbo, S.P., Grocke, D.R., Jenkyns, H.C., Bjerrum, C.J., Farrimond, P., Bell, H.S.M. \& Green, O.R. 2000. Massive dissociation of gas hydrate during a Jurassic oceanic anoxic event. Nature, 406 (6794), 392-395.

Hoar, M.R., Palutikof, J.P. \& Thorne, M.C. 2004. Model intercomparison for the present day, the mid-Holocene, and the Last Glacial Maximum over western Europe. Journal of Geophysical Research-Atmospheres, 109 (D8).

Hodell, D.A., Curtis, J.H., Sierro, F.J. \& Raymo, M.E. 2001. Correlation of late Miocene to early Pliocene sequences between the Mediterranean and North Atlantic. Paleoceanography, 16 (2), 164-178.

Hodell, D.A., Elmstrom, K.M. \& Kennett, J.P. 1986. Latest Miocene benthic $\delta 180$ changes, global ice volume, sea-level and the Messinian salinity crisis. Nature, 320 (6061), 411-414.

Hoefs, M.J.L., Versteegh, G.J.M., Rijpstra, W.I.C., de Leeuw, J.W. \& Damste, J.S.S. 1998. Postdepositional oxic degradation of alkenones: Implications for the measurement of palaeo sea surface temperatures. Paleoceanography, 13 (1), 42-49.

Hoffman, P.F., Kaufman, A.J., Halverson, G.P. \& Schrag, D.P. 1998. A Neoproterozoic snowball Earth. Science, 281 (5381), 1342-1346.

Hofmann, C., Courtillot, V., Feraud, G., Rochette, P., Yirgu, G., Ketefo, E. \& Pik, R. 1997. Timing of the Ethiopian flood basalt event and implications for plume birth and global change. Nature, 389 (6653), 838-841.

Holbourn, A., Kuhnt, W., Schulz, M. \& Erlenkeuser, H. 2005. Impacts of orbital forcing and atmospheric carbon dioxide on Miocene ice-sheet expansion. Nature, 438 (7067), 483-487.

Holland, H.D. 2004. Sea level, sediments, and the composition of Phanerozoic seawater. Geochimica et Cosmochimica Acta, 68 (11), A332-A332.

Hollander, D.J., McKenzie, J.A. \& Hsu, K.J. 1993. Carbon isotope evidence for unusual plankton blooms and fluctuations of surface water $\mathrm{CO}_{2}$ in Strangelove Ocean after terminal Cretaceous event. Palaeogeography Palaeoclimatology Palaeoecology, 104 (1-4), 229-237.

Honisch, B., Hemming, N.G., Grottoli, A.G., Amat, A., Hanson, G.N. \& Buma, J. 2004. Assessing scleractinian corals as recorders for paleo-pH: Empirical calibration and vital effects. Geochimica et Cosmochimica Acta, 68 (18), 3675-3685.

Hooper, P.R., Binger, G.B. \& Lees, K.R. 2002. Ages of the Steens and Columbia River flood basalts and their relationship to extension-related calc-alkalic volcanism in eastern Oregon. Geological Society of America Bulletin, 114 (1), 43-50.

House, J.I., Prentice, I.C., Ramankutty, N., Houghton, R.A. \& Heimann, M. 2003. Reconciling apparent inconsistencies in estimates of terrestrial CO2 sources and sinks. Tellus Series B-Chemical and Physical Meteorology, 55 (2), 345-363.

Huber, B.T., MacLeod, K.G. \& Wing, S.L. 2000. Warm Climates in Earth History, Cambridge University Press, Cambridge, xi,455.

Hutchison, J.H. 1982. Turtle, crocodilian, and champsosaur diversity changes in the Cenozoic of the north-central region of western United States. Palaeogeography Palaeoclimatology Palaeoecology, 37 (2-4), 149-164.

Huynh, T.T. \& Poulsen, C.J. 2005. Rising atmospheric $\mathrm{CO}_{2}$ as a possible trigger for the endTriassic mass extinction. Palaeogeography Palaeoclimatology Palaeoecology, 217 (3-4), 223-242. 
Igamberdiev, A.U. \& Lea, P.J. 2006. Land plants equilibrate O-2 and CO2 concentrations in the atmosphere. Photosynthesis Research, 87 (2), 177-194.

Imbrie, J. \& Kipp, N. 1971. A new micropalaeontological method for quantitative paleoclimatology: application to late Pleistocene Caribbean core V28-238. In: Turekian, K.K. (ed.) The late Cenozoic Glacial Ages. Yale University Press, New Haven, 77-181.

Imbrie, J. \& Newell, N. 1964. Approaches to Paleoecology. John Wiley and Sons Inc., New York.

Immenhauser, A. 2005. High-rate sea-level change during the Mesozoic: New approaches to an old problem. Sedimentary Geology, 175 (1-4), 277-296.

Ingle, S., Scoates, J.S., Weis, D., Brugmann, G. \& Kent, R.W. 2004. Origin of cretaceous continental tholefites in southwestern Australia and eastern India: insights from Hf and Os isotopes. Chemical Geology, 209 (1-2), 83-106.

IPCC 2001. Climate Change 2001: the scientific basis - contribution of working group I to the third assessment report of IPCC.

Irving, E. 2005. The role of latitude in mobilism debates. Proceedings of the National Academy of Sciences of the United States of America, 102 (6), 1821-1828.

Isbell, J.L., Miller, M.F., Babcock, L.E. \& Hasiotis, S.T. 2001. Ice-marginal environment and ecosystem prior to initial advance of the late Palaeozoic ice sheet in the Mount Butters area of the central Transantarctic Mountains, Antarctica. Sedimentology, 48 (5), 953970.

Isozaki, Y., Kawahata, H. \& Ota, A. 2006. A unique carbon isotope record across the Guadalupian-Lopingian (Permian) boundary in Panthalassan paleoatoll carbonates: the high-productivity "Kamura event" and its collapse. Geophysical Research Abstracts, 8, 5365.

James, N.P., Narbonne, G.M., Dalrymple, R.W. \& Kyser, T.K. 2005. Glendonites in Neoproterozoic low-latitude, interglacial, sedimentary rocks, northwest Canada: Insights into the Cryogenian ocean and Precambrian cold-water carbonates. Geology, 33 (1), 9-12.

Jelsma, H.A., de Wit, M.J., Thiart, C., Dirks, P., Viola, G., Basson, I.J. \& Anckar, E. 2004. Preferential distribution along transcontinental corridors of kimberlites and related rocks of Southern Africa. South African Journal of Geology, 107 (1-2), 301-324.

Jenkyns, H.C. 2003. Evidence for rapid climate change in the Mesozoic-Palaeogene greenhouse world. Philosophical Transactions of the Royal Society of London Series a-Mathematical Physical and Engineering Sciences, 361 (1810), 1885-1916.

Jenkyns, H.C., Grocke, D.R. \& Hesselbo, S.P. 2001. Nitrogen isotope evidence for water mass denitrification during the early Toarcian (Jurassic) oceanic anoxic event. Paleoceanography, 16 (6), 593-603.

Jeppsson, L. \& Aldridge, R.J. 2000. Ludlow (late Silurian) oceanic episodes and events. Journal of the Geological Society, 157, 1137-1148.

Jeppsson, L. \& Calner, M. 2003. The Silurian Mulde Event and a scenario for secundosecundo events. Transactions of the Royal Society of Edinburgh-Earth Sciences, 93, $135-154$.

Jimenez-Espinosa, R. \& Jimenez-Millan, J. 2003. Calcrete development in mediterranean colluvial carbonate systems from SE Spain. Journal of Arid Environments, 53 (4), 479-489.

Jimenez-Moreno, G., Rodriguez-Tovar, F.J., Pardo-Iguzquiza, E., Fauquette, S., Suc, J.P. \& Muller, P. 2005. High-resolution palynological analysis in late early-middle Miocene core from the Pannonian Basin, Hungary: climatic changes, astronomical forcing and 
eustatic fluctuations in the Central Paratethys. Palaeogeography Palaeoclimatology Palaeoecology, 216 (1-2), 73-97.

Joachimski, M.M., Simon, L., van Geldern, R. \& Lecuyer, C. 2005. Boron isotope geochemistry of Paleozoic brachiopod calcite: Implications for a secular change in the boron isotope geochemistry of seawater over the Phanerozoic. Geochimica et Cosmochimica Acta, 69 (16), 4035-4044.

Johnson, J.S. \& Smellie, J.L. in press. Zeolite compositions as proxies for eruptive palaeoenvironment. Geochemistry Geophysics Geosystems.

Jones, G.S., Gregory, J.M., Stott, P.A., Tett, S.F.B. \& Thorpe, R.B. 2005. An AOGCM simulation of the climate response to a volcanic super-eruption. Climate Dynamics, 25 (7-8), 725-738.

Jones, I.W., Munhoven, G., Tranter, M., Huybrechts, P. \& Sharp, M.J. 2002. Modelled glacial and non-glacial $\mathrm{HCO}_{3}{ }^{-}$, Si and Ge fluxes since the LGM: little potential for impact on atmospheric $\mathrm{CO} 2$ concentrations and a potential proxy of continental chemical erosion, the marine Ge/Si ratio. Global and Planetary Change, 33, 139-153.

Kafanov, A.I. \& Volvenko, I.V. 1997. Bivalve molluscs and Cenozoic paleoclimatic events in the northwestern Pacific Ocean. Palaeogeography Palaeoclimatology Palaeoecology, 129 (1-2), 119-153.

Kaljo, D., Martma, T., Mannik, P. \& Viira, V. 2003. Implications of Gondwana glaciations in the Baltic late Ordovician and Silurian and a carbon isotopic test of environmental cyclicity. Bulletin De La Société Géologique De France, 174 (1), 59-66.

Kasemann, S.A., Hawkesworth, C.J., Prave, A.R., Fallick, A.E. \& Pearson, P.N. 2005. Boron and calcium isotope composition in Neoproterozoic carbonate rocks from Namibia: evidence for extreme environmental change. Earth and Planetary Science Letters, 231 (1-2), 73-86.

Kaufman, D.S. \& Brighamgrette, J. 1993. Aminostratigraphic correlations and paleotemperature implications, Pliocene-Pleistocene high-sea-level deposits, northwestern Alaska. Quaternary Science Reviews, 12 (1), 21-33.

Kawagata, S., Hayward, B.W., Grenfell, H.R. \& Sabaa, A. 2005. Mid-Pleistocene extinction of deep-sea foraminifera in the North Atlantic Gateway (ODP sites 980 and 982). Palaeogeography Palaeoclimatology Palaeoecology, 221 (3-4), 267-291.

Kawagata, S., Hayward, B.W. \& Gupta, A.K. 2006. Benthic foraminiferal extinctions linked to late Pliocene-Pleistocene deep-sea circulation changes in the northern Indian Ocean (ODP Sites 722 and 758). Marine Micropaleontology, 58 (3), 219-242.

Keany, J., Ledbetter, M., Watkins, N. \& Huang, T.C. 1976. Diachronous deposition of icerafted debris in sub-Antarctic deep sea sediments. Geological Society of America Bulletin, 87 (6), 873-882.

Keller, G. 2004. Low-diversity, late Maastrichtian and early Danian planktic foraminiferal assemblages of the eastern Tethys. Journal of Foraminiferal Research, 34 (1), 49-73.

Keller, G., Adatte, T., Stinnesbeck, W., Luciani, V., Karoui-Yaakoub, N. \& Zaghbib-Turki, D. 2002. Paleoecology of the Cretaceous-Tertiary mass extinction in planktonic foraminifera. Palaeogeography Palaeoclimatology Palaeoecology, 178 (3-4), 257297.

Kennedy, E.M. 2003. Late Cretaceous and Paleocene terrestrial climates of New Zealand: leaf fossil evidence from South Island assemblages. New Zealand Journal of Geology and Geophysics, 46 (2), 295-306.

Kennett, J.P. 1977. Cenozoic evolution of Antarctic glaciation, the circum-Antarctic Ocean, and their impact on global paleoceanography. Journal of Geophysical Research, 82, $3843-3860$. 
Kerrick, D.M. 2001. Present and past nonanthropogenic CO2 degassing from the solid Earth. Reviews of Geophysics, 39 (4), 565-585.

Kerrick, D.M. \& Caldeira, K. 1999. Was the Himalayan orogen a climatically significant coupled source and sink for atmospheric $\mathrm{CO} 2$ during the Cenozoic? Earth and Planetary Science Letters, 173 (3), 195-203.

Kieffer, B., Arndt, N., Lapierre, H., Bastien, F., Bosch, D., Pecher, A., Yirgu, G., Ayalew, D., Weis, D., Jerram, D.A., Keller, F. \& Meugniot, C. 2004. Flood and shield basalts from Ethiopia: magmas from the African Superswell. Journal of Petrology, 45 (4), 793-834, 10.1093/petrology/egg108.

Kiessling, W., Flugel, E. \& Golonka, J. 2003. Patterns of Phanerozoic carbonate platform sedimentation. Lethaia, 36 (3), 195-225.

Kirkland, C.L., Daly, J.S., Eide, E.A. \& Whitehouse, M.J. 2006. The structure and timing of lateral escape during the Scandian Orogeny: A combined strain and geochronological investigation in Finnmark, Arctic Norwegian Caledonides. Tectonophysics, 425 (1-4), 159-189.

Kitamura, A. \& Kawagoe, T. 2006. Eustatic sea-level change at the Mid-Pleistocene climate transition: new evidence from the shallow-marine sediment record of Japan. Quaternary Science Reviews, 25 (3-4), 323-335.

Klein, G.d. 1990. Pennsylvanian time scales and cycle periods. Geology, 18 (5), 455-457, 10.1130/0091-7613(1990)018<0455:PTSACP $>2.3 . C O ; 2$.

Klotz, S., Fauquette, S., Combourieu-Nebout, N., Uhl, D., Suc, J.P. \& Mosbrugger, V. 2006. Seasonality intensification and long-term winter cooling as a part of the Late Pliocene climate development. Earth and Planetary Science Letters, 241 (1-2), 174-187.

Knies, J., Matthiessen, J., Vogt, C. \& Stein, R. 2002. Evidence of 'Mid-Pliocene (similar to 3 Ma) global warmth' in the eastern Arctic Ocean and implications for the Svalbard/Barents Sea ice sheet during the late Pliocene and early Pleistocene (similar to 3-1.7 Ma). Boreas, 31 (1), 82-93.

Knoll, A.H., Bambach, R.K., Canfield, D.E. \& Grotzinger, J.P. 1996. Comparative earth history and Late Permian mass extinction. Science, 273 (5274), 452-457.

Knoll, A.H., Walter, M.R., Narbonne, G.M. \& Christie-Blick, N. 2006. The Ediacaran Period: a new addition to the geologic time scale. Lethaia, 39 (1), 13-30.

Kohfeld, K.E. \& Harrison, S.P. 2000. How well can we simulate past climates? Evaluating the models using global palaeoenvironmental datasets. Quaternary Science Reviews, 19 (1-5), 321-346.

Kohfeld, K.E. \& Harrison, S.P. 2001. DIRTMAP: the geological record of dust. EarthScience Reviews, 54 (1-3), 81-114.

Köppen, V.P. \& Wegener, A. 1924. Die Klimate der Geologischen Vorzeit. Gebrüder Bornträger, Berlin.

Korhola, A., Birks, H.J.B., Olander, H. \& Blom, T. 2001. Chironomids, temperature and numerical models: a reply to Seppala. Holocene, 11 (5), 615-622.

Korte, C., Kozur, H.W. \& Veizer, J. 2005. delta C-13 and delta O-18 values of Triassic brachiopods and carbonate rocks as proxies for coeval seawater and palaeotemperature. Palaeogeography Palaeoclimatology Palaeoecology, 226 (3-4), 287-306.

Krijgsman, W., Garces, M., Agusti, J., Raffi, I., Taberner, C. \& Zachariasse, W.J. 2000. The 'Tortonian salinity crisis' of the eastern Betics (Spain). Earth and Planetary Science Letters, 181 (4), 497-511.

Krijgsman, W., Hilgen, F.J., Raffi, I., Sierro, F.J. \& Wilson, D.S. 1999. Chronology, causes and progression of the Messinian salinity crisis. Nature, 400 (6745), 652-655. 
Kucera, M. \& Darling, K.F. 2002. Cryptic species of planktonic foraminifera: their effect on palaeoceanographic reconstructions. Philosophical Transactions of the Royal Society of London Series A-Mathematical Physical and Engineering Sciences, 360 (1793), 695-718.

Kumar, N., Anderson, R.F., Mortlock, R.A., Froelich, P.N., Kubik, P., Dittrichhannen, B. \& Suter, M. 1995. Increased biological productivity and export production in the glacial Southern Ocean. Nature, 378 (6558), 675-680.

Kump, L.R. 2002. Reducing uncertainty about carbon dioxide as a climate driver. Nature, 419 (6903), 188-190, 10.1038/nature01087.

Kusakabe, M., Ku, T.L., Southon, J.R., Vogel, J.S., Nelson, D.E., Measures, C.I. \& Nozaki, Y. 1987. Distribution of ${ }^{10} \mathrm{Be}$ and ${ }^{9} \mathrm{Be}$ in the Pacific Ocean. Earth and Planetary Science Letters, 82 (3-4), 231-240, 10.1016/0012-821X(87)90198-1.

Kutzbach, J.E. \& Gallimore, R.G. 1989. Pangaean climates : megamonsoons of the megacontinent. Journal of Geophysical Research-Atmospheres, 94 (D3), 3341-3357.

Kutzbach, J.E. \& Ziegler, A.M. 1993. Simulation of Late Permian climate and biomes with an atmosphere ocean model: comparisons with observations. Philosophical Transactions of the Royal Society of London Series B-Biological Sciences, 341 (1297), 327-340.

Lagroix, F. \& Banerjee, S.K. 2002. Paleowind directions from the magnetic fabric of loess profiles in central Alaska. Earth and Planetary Science Letters, 195 (1-2), 99-112.

Larson, R.L. 1991. Geological consequences of superplumes. Geology, 19 (10), 963-966.

Larson, R.L. 1995. The mid-Cretaceous superplume episode. Scientific American, 272 (2), $82-86$.

Lasaga, A.C. \& Berner, R.A. 1998. Fundamental aspects of quantitative models for geochemical cycles. Chemical Geology, 145 (3-4), 161-175.

Lauriol, B. \& Clark, I. 1999. Fissure calcretes in the arctic: a paleohydrologic indicator. Applied Geochemistry, 14 (6), 775-785.

Le Guern, P. \& Davaud, E. 2005. Recognition of ancient carbonate wind deposits: lessons from a modern analogue, Chrissi Island, Crete. Sedimentology, 52 (5), 915-926.

Le Guerroue, E., Allen, P.A., Cozzi, A., Etienne, J.L. \& Fanning, M. 2006. 50 Myr recovery from the largest negative delta C-13 excursion in the Ediacaran ocean. Terra Nova, 18 (2), 147-153.

Lea, D.W. 1993. Constraints on the alkalinity and circulation of glacial circumpolar deep water from benthic foraminiferal barium. Global Biogeochemical Cycles, 7 (3), 695710.

Lear, C.H., Elderfield, H. \& Wilson, P.A. 2003a. A Cenozoic seawater Sr/Ca record from benthic foraminiferal calcite and its application in determining global weathering fluxes. Earth and Planetary Science Letters, 208 (1-2), 69-84.

Lear, C.H., Rosenthal, Y. \& Wright, J.D. 2003b. The closing of a seaway: ocean water masses and global climate change. Earth and Planetary Science Letters, 210 (3-4), 425-436.

Lees, J.A. 2002. Calcareous nannofossil biogeography illustrates palaeoclimate change in the Late Cretaceous Indian Ocean. Cretaceous Research, 23 (5), 537-633.

Legendre, S. 1986. Analysis of mammalian communities from the late Eocene and Oligocene of southern France. Palaeovertebrata, 16, 191-212.

Legendre, S., Montuire, S., Maridet, O. \& Escarguel, G. 2005. Rodents and climate: A new model for estimating past temperatures. Earth and Planetary Science Letters, 235 (12), 408-420.

Legrand, P. 2003. Late Ordovician-early Silurian paleogeography of the Algerian Sahara. Bulletin De La Societe Geologique De France, 174 (1), 19-32. 
Leinfelder, R.R., Schlagintweit, F., Werner, W., Ebli, O., Nose, M., Schmid, D.U. \& Hughes, G.W. 2005. Significance of stromatoporoids in Jurassic reefs and carbonate platforms - concepts and implications. Facies, 51 (1-4), 299-337.

Leng, M.J. \& Barker, P.A. 2006. A review of the oxygen isotope composition of lacustrine diatom silica for palaeoclimate reconstruction. Earth-Science Reviews, 75 (1-4), 5-27.

Lenton, T.M. 2001. The role of land plants, phosphorus weathering and fire in the rise and regulation of atmospheric oxygen. Global Change Biology, 7 (6), 613-629.

Lenton, T.M. \& Watson, A.J. 2000. Redfield revisited 2. What regulates the oxygen content of the atmosphere? Global Biogeochemical Cycles, 14 (1), 249-268.

Lewis, J.P., Weaver, A.J., Johnston, S.T. \& Eby, M. 2003. Neoproterozoic "snowball Earth": Dynamic sea ice over a quiescent ocean. Paleoceanography, 18 (4), art. no.-1092.

Li, J.G., Philp, R.P., Pu, F. \& Allen, J. 1996. Long-chain alkenones in Qinghai Lake sediments. Geochimica et Cosmochimica Acta, 60 (2), 235-241.

Li, Y.-H. 1972. Geochemical mass balance among lithosphere, hydrosphere, and atmosphere. American Journal of Science, 272 (2), 119-137.

Lin, H.L. \& Chen, C.J. 2002. A late pliocene diatom Ge/Si record from the Southeast Atlantic. Marine Geology, 180 (1-4), 151-161.

Ling, H.F., Burton, K.W., O'Nions, R.K., Kamber, B.S., von Blanckenburg, F., Gibb, A.J. \& Hein, J.R. 1997. Evolution of $\mathrm{Nd}$ and $\mathrm{Pb}$ isotopes in Central Pacific seawater from ferromanganese crusts. Earth and Planetary Science Letters, 146 (1), 1-12, 10.1016/S0012-821X(96)00224-5.

Liu, Z., Gallimore, R.G., Kutzbach, J.E., Xu, W., Golubev, Y., Behling, P. \& Selin, R. 1999. Modeling long-term climate changes with equilibrium asynchronous coupling. Climate Dynamics, 15 (5), 325-340.

Livermore, R.A., Eagles, G., Morris, P. \& Maldonado, A. 2004. Shackleton Fracture Zone: no barrier to early circumpolar ocean circulation. Geology, 32 (9), 797-800.

Loboziak, S., Streel, M. \& Dealmeidaburjack, M.I. 1989. Paleoclimatic Conclusions from a Comparison between Middle-Upper Devonian Miospores Assemblages from Libya and Brazil. Geobios, 22 (2), 247-251.

Lohmann, G.P. 1995. A model for variation in the chemistry of planktonic foraminifera due to secondary calcification and selective dissolution. Paleoceanography, 10 (3), 445457.

Loutre, M.F. \& Berger, A. 2000. Future climatic changes: are we entering an exceptionally long interglacial? Climatic Change, 46 (1-2), 61-90, 10.1023/A:1005559827189.

Lowenstein, T.K., Timofeeff, M.N., Brennan, S.T., Hardie, L.A. \& Demicco, R.V. 2001. Oscillations in Phanerozoic seawater chemistry: Evidence from fluid inclusions. Science, 294 (5544), 1086-1088.

Ludwig, K.R. 1999. Isoplot Ex version 2, Berkeley Geochronology Center, Berkeley.

Lyell, C. 1830. Principles of Geology.

Lynch-Stieglitz, J. \& Fairbanks, R.G. 1994. A conservative tracer for glacial ocean circulation from carbon isotope and palaeo-nutrient measurements in benthic foraminifera. Nature, 369, 308-310, 10.1038/369308a0.

MacGinitie, H.D. 1941. A Middle Eocene flora from the central Sierra Nevada. Carnegie Institute of Washington Publications, 534, 1-94.

Mack, G.H. \& Cole, D.R. 2005. Geochemical model of delta O-18 of pedogenic calcite versus latitude and its application to Cretaceous palaeoclimate. Sedimentary Geology, $174(1-2), 115-122$.

Mack, G.H. \& James, W.C. 1994. Paleoclimate and the global distribution of paleosols. Journal of Geology, 102 (3), 360-366. 
Mack, G.H., James, W.C. \& Monger, H.C. 1993. Classification of paleosols. Geological Society of America Bulletin, 105 (2), 129-136.

Mackensen, A. 2004. Changing Southern Ocean palaeocirculation and effects on global climate. Antarctic Science, 16 (4), 369-386.

Malmgren, B.A. \& Nordlund, U. 1997. Application of artificial neural networks to paleoceanographic data. Palaeogeography Palaeoclimatology Palaeoecology, 136 (14), 359-373.

Manabe, S. \& Bryan, K. 1969. Climate calculations with a combined ocean-atmosphere model. Journal of the Atmospheric Sciences, 26 (4), 786-789.

Marchitto, T.M., Curry, W.B. \& Oppo, D.W. 2000. Zinc concentrations in benthic foraminifera reflect seawater chemistry. Paleoceanography, 15 (3), 299-306.

Maréchal, C.N., Nicolas, E., Douchet, C. \& Albarède, F. 2000. Abundance of zinc isotopes as a marine biogeochemical tracer. Geochemistry Geophysics Geosystems, 1 (5), 10.1029/1999GC000029.

Markwick, P.J. 1998. Fossil crocodilians as indicators of Late Cretaceous and Cenozoic climates: implications for using palaeontological data in reconstructing palaeoclimate. Palaeogeography Palaeoclimatology Palaeoecology, 137 (3-4), 205-271.

Marotzke, J. \& Willebrand, J. 1991. Multiple equilibria of the global thermohaline circulation. Journal of Physical Oceanography, 21 (9), 1372-1385.

Marriott, C.S., Henderson, G.M., Belshaw, N.S. \& Tudhope, A.W. 2004. Temperature dependence of delta $\mathrm{Li}-7$, delta $\mathrm{Ca}-44$ and $\mathrm{Li} / \mathrm{Ca}$ during growth of calcium carbonate. Earth and Planetary Science Letters, 222 (2), 615-624.

Marshall, J.D. 1992. Climatic and oceanographic isotopic signals from the carbonate rock record and their preservation. Geological Magazine, 129 (2), 143-160.

Marshall, J.D., Brenchley, P.J., Mason, P., Wolff, G.A., Astini, R.A., Hints, L. \& Meidla, T. 1997. Global carbon isotopic events associated with mass extinction and glaciation in the late Ordovician. Palaeogeography Palaeoclimatology Palaeoecology, 132 (1-4), 195-210.

Maslin, M., Vilela, C., Mikkelsen, N. \& Grootes, P. 2005. Causes of catastrophic sediment failures of the Amazon Fan. Quaternary Science Reviews, 24 (20-21), 2180-2193.

Matsumoto, K., Sarmiento, J.L. \& Brzezinski, M.A. 2002. Silicic acid leakage from the Southern Ocean: A possible explanation for glacial atmospheric $\mathrm{pCO}(2)$. Global Biogeochemical Cycles, 16 (3).

McArthur, J.M., Howarth, R.J. \& Bailey, T.R. 2001. Strontium isotope stratigraphy: LOWESS Version 3: best fit to the marine Sr-Isotope curve for 0-509 Ma and accompanying look-up table for deriving numerical age. Journal of Geology, 109, $155-170$.

McCabe, P.J. 1991. Tectonic controls on coal accumulation. Bulletin de la Société Géologique de France, 162 (2), 277-282.

McCabe, P.J. \& Parrish, J.T. 1992. Tectonic and climatic controls on the distribution and quality of Cretaceous coals. In: McCabe, P.J. \& Parrish, J.T. (eds) Controls on the distribution and quality of Cretaceous coals. Geological Society of America Special Papers, 267, 1-15.

McCabe, P.J. \& Shanley, K.W. 1992. Organic control on shoreface stacking patterns: bogged down in the mire. Geology, 20 (8), 741-744.

McCave, I.N., Manighetti, B. \& Robinson, S.G. 1995. Sortable silt and fine sediment size composition slicing: parameters for paleocurrent speed and paleoceanography. Paleoceanography, 10 (3), 593-610.

McElwain, J.C., Beerling, D.J. \& Woodward, F.I. 1999. Fossil plants and global warming at the Triassic-Jurassic boundary. Science, 285 (5432), 1386-1390. 
McElwain, J.C., Wade-Murphy, J. \& Hesselbo, S.P. 2005. Changes in carbon dioxide during an oceanic anoxic event linked to intrusion into Gondwana coals. Nature, 435 (7041), 479-482.

McGuffie, K. \& Henderson-Sellers, A. 2001. Forty years of numerical climate modelling. International Journal of Climatology, 21 (9), 1067-1109.

McHone, J.G. 2002. Volatile emissions of Central Atlantic Magmatic Province basalts: mass assumptions and environmental consequences. In: Hames, W.E., McHone, J.G., Renne, P.R. \& Ruppel, C. (eds) The Central Atlantic Magmatic Province. American Geophysical Union Geophysical Monographs, 136, 241-254.

McLachlan, I.R., Tsikos, H. \& Cairncross, B. 2001. Glendonites (pseudomorphs after ikaite) in Late Carboniferous marine Dwyka beds in southern Africa. South African Journal of Geology, 104 (3), 265-272.

Medvedev, A.Y., Al'mukhamedov, A.I. \& Kirda, N.P. 2003. Geochemistry of PermoTriassic volcanic rocks of West Siberia. Geologiya I Geofizika, 44 (1-2), 86-100.

Meert, J.G. 2003. A synopsis of events related to the assembly of eastern Gondwana. Tectonophysics, 362 (1-4), 1-40.

Mercer, J.H. \& Sutter, J.F. 1982. Late Miocene earliest-Pliocene glaciation in southern Argentina: implications for global icesheet history. Palaeogeography Palaeoclimatology Palaeoecology, 38 (3-4), 185-206.

Michaelsen, P. \& Henderson, R.A. 2000. Facies relationships and cyclicity of high-latitude, Late Permian coal measures, Bowen Basin, Australia. International Journal of Coal Geology, 44 (1), 19-48.

Milankovitch, M. 1941. Canon of insolation and the ice-age problem, Royal Serbian Academy, Special Publications, Volume 132, Translated from German by Israel Program for Scientific Translations, Jerusalem, 633.

Miller, K.G., Sugarman, P.J., J.V., B., Kominz, M.A., Hernández, J.C., Olsson, R.K., Wright, J.D., Feigenson, M.D. \& Van Sickel, W. 2003. Late Cretaceous chronology of large, rapid sea-level changes: glacioeustasy during the greenhouse world. Geology, 31 (7), 585-588.

Miller, K.G., Wright, J.D. \& Browning, J.V. 2005. Visions of ice sheets in a greenhouse world. Marine Geology, 217 (3-4), 215-231.

Miller, K.G., Wright, J.D. \& Fairbanks, R.G. 1991. Unlocking the ice house: OligoceneMiocene oxygen isotopes, eustasy, and margin erosion. Journal of Geophysical Research-Solid Earth and Planets, 96 (B4), 6829-6848.

Moe, A.P. \& Smith, D.M. 2005. Using pre-Quaternary Diptera as indicators of paleoclimate. Palaeogeography Palaeoclimatology Palaeoecology, 221 (3-4), 203-214.

Mohseni, H. \& Al-Aasm, I.S. 2004. Tempestite deposits on a storm-influenced carbonate ramp: An example from the Pabdeh formation (Paleogene), Zagros Basin, SW. Journal of Petroleum Geology, 27 (2), 163-178.

Moine, O. \& Rousseau, D.D. 2002. Terrestrial molluscs and temperature: a new quantitative transfer function. Comptes Rendus Palevol, 1 (3), 145-151.

Montoya, M., Crowley, T.J. \& von Storch, H. 1998. Temperatures at the last interglacial simulated by a coupled ocean-atmosphere climate model. Paleoceanography, 13 (2), $170-177$.

Moore, J.M., Tsikos, H. \& Polteau, S. 2001. Deconstructing the Transvaal Supergroup, South Africa: implications for Palaeoproterozoic palaeoclimate models. Journal of African Earth Sciences, 33 (3-4), 437-444.

Moore, P.D. 1995. Biological processes controlling the development of modern peat-forming ecosystems. International Journal of Coal Geology, 28 (2-4), 99-110. 
Moran, K., Backman, J., Brinkhuis, H.and 36 others 2006. The Cenozoic palaeoenvironment of the Arctic Ocean. Nature, 441, 601-605, doi:10.1038/nature04800.

Morard, A., Guex, J., Bartolini, A., Morettini, E. \& De Wever, P. 2003. A new scenario for the Domerian - Toarcian transition. Bulletin De La Societe Geologique De France, 174 (4), 351-356.

Morgans, H.S. 1999. Lower and Middle Jurassic woods of the Cleveland Basin (North Yorkshire), England. Palaeontology, 42, 303-328.

Mory, A.J., Iasky, R.P., Glikson, A.Y. \& Pirajno, F. 2000. Woodleigh, Carnarvon Basin, Western Australia: a new $120 \mathrm{~km}$ diameter impact structure. Earth and Planetary Science Letters, 177 (1-2), 119-128.

Munhoven, G. \& Francois, L.M. 1996. Glacial-interglacial variability of atmospheric $\mathrm{CO}_{2}$ due to changing continental silicate rock weathering: A model study. Journal of Geophysical Research-Atmospheres, 101 (D16), 21423-21437.

Murphy, J.B. \& Nance, R.D. 2005. Do supercontinents turn inside-in or inside-out? International Geology Review, 47 (6), 591-619.

Murphy, J.B., Pisarevsky, S.A., Nance, R.D. \& Keppie, J.D. 2004. Neoproterozoic-Early Paleozoic evolution of peri-Gondwanan terranes: implications for LaurentiaGondwana connections. International Journal of Earth Sciences, 93 (5), 659-682.

Murray-Wallace, C.V., Kimber, R.W.L. \& Belperio, A.P. 1988. Holocene paleotemperature studies using amino acid racemization reactions. Australian Journal of Earth Sciences, 35 (4), 575-577.

Muttoni, G., Carcano, C., Garzanti, E., Ghielmi, M., Piccin, A., Pini, R., Rogledi, S. \& Sciunnach, D. 2003. Onset of major Pleistocene glaciations in the Alps. Geology, 31 (11), 989-992.

Myrow, P.M. \& Southard, J.B. 1996. Tempestite deposition. Journal of Sedimentary Research, 66 (5), 875-887.

Nairn, A.E.M. 1961. Descriptive Palaeoclimatology. Interscience Publishers, New York.

Nakai, S., Halliday, A.N. \& Rea, D.K. 1993. Provenance of dust in the Pacific Ocean. Earth and Planetary Science Letters, 119 (1-2), 143-157.

Nisbet, E.G. 1992. Sources of atmospheric $\mathrm{CH}_{4}$ in early postglacial time. Journal of Geophysical Research-Atmospheres, 97 (D12), 12859-12867.

Nisbet, E.G. 2002. Have sudden large releases of methane from geological reservoirs occurred since the Last Glacial Maximum, and could such releases occur again? Philosophical Transactions of the Royal Society of London Series a-Mathematical Physical and Engineering Sciences, 360 (1793), 581-607.

Noiri, Y., Kudo, I., Kiyosawa, H., Nishioka, J. \& Tsuda, A. 2005. Influence of iron and temperature on growth, nutrient utilization ratios and phytoplankton species composition in the western subarctic Pacific Ocean during the SEEDS experiment. Progress in Oceanography, 64 (2-4), 149-166.

Nordt, L., Atchley, S. \& Dworkin, S.I. 2002. Paleosol barometer indicates extreme fluctuations in atmospheric $\mathrm{CO} 2$ across the Cretaceous-Tertiary boundary. Geology, 30 (8), 703-706.

Nordt, L.C., Wilding, L.P., Lynn, W.C. \& Crawford, C.C. 2004. Vertisol genesis in a humid climate of the coastal plain of Texas, USA. Geoderma, 122 (1), 83-102.

O'Brien, P.E., Lindsay, J.F., Knauer, K. \& Sexton, M.J. 1998. Sequence stratigraphy of a sandstone-rich Permian glacial succession, Fitzroy Trough, Canning Basin, Western Australia. Australian Journal of Earth Sciences, 45 (4), 533-545.

Olsen, P.E. 2001. Grand cycles of the Milankovitch band. Eos Transactions, 82 (47), F2. 
Otto-Bliesner, B.L. 1995. Continental drift, runoff, and weathering feedbacks: implications from climate model experiments. Journal of Geophysical Research-Atmospheres, 100 (D6), 11537-11548.

Otto-Bliesner, B.L., Brady, E.C. \& Shields, C. 2002. Late Cretaceous ocean: coupled simulations with the National Center for Atmospheric Research climate system model. Journal of Geophysical Research-Atmospheres, 107 (D1-D2).

Otto-Bliesner, B.L. \& Upchurch, G.R. 1997. Vegetation-induced warming of high-latitude regions during the late Cretaceous period. Nature, 385 (6619), 804-807.

Ourbak, T., Correge, T., Malaize, B., Le Cornec, F., Charlier, K. \& Peypouquet, J.P. 2006. A high-resolution investigation of temperature, salinity, and upwelling activity proxies in corals. Geochemistry Geophysics Geosystems, 7.

Pagani, M. 2002. The alkenone- $\mathrm{CO}_{2}$ proxy and ancient atmospheric carbon dioxide. Philosophical Transactions of the Royal Society of London Series A-Mathematical Physical and Engineering Sciences, 360 (1793), 609-632.

Pagani, M., Lemarchand, D., Spivack, A. \& Gaillardet, J. 2005a. A critical evaluation of the boron isotope-pH proxy: The accuracy of ancient ocean $\mathrm{pH}$ estimates. Geochimica et Cosmochimica Acta, 69 (4), 953-961.

Pagani, M., Zachos, J.C., Freeman, K.H., Tipple, B. \& Bohaty, S. 2005b. Marked decline in atmospheric carbon dioxide concentrations during the Paleogene. Science, 309 (5734), 600-603.

Page, A., Zalasiewicz, J., Williams, M. \& Popov, L. in press. Were transgressive black shales a negative feedback modulating glacioeustasy in the Early Palaeozoic Icehouse? In: Williams, M., Haywood, A. \& Gregory, J. (eds) Deep time perspectives on climate change: marrying the signal from computer models and biological proxies. Geological Society of London, Special Publication.

Pálfy, J. \& Smith, P.L. 2000. Synchrony between Early Jurassic extinction, oceanic anoxic event, and the Karoo-Ferrar flood basalt volcanism. Geology, 28 (8), 747-750.

Palmer, A.R. 1983. The Decade of North-American Geology - 1983 Geologic Time Scale. Geology, 11 (9), 503-504.

Park, J. \& Maasch, K.A. 1993. Plio-Pleistocene time evolution of the 100-Kyr cycle in marine paleoclimate records. Journal of Geophysical Research-Solid Earth, 98 (B1), 447-461.

Parrish, J.T. 1993. A brief discussion of the history, strengths and limitations of conceptual climate models for pre-Quaternary time. Philosophical Transactions of the Royal Society of London Series B-Biological Sciences, 341 (1297), 263-266.

Parrish, J.T., Ziegler, A.M. \& Scotese, C.R. 1982. Rainfall patterns and the distribution of coals and evaporites in the Mesozoic and Cenozoic. Palaeogeography Palaeoclimatology Palaeoecology, 40, 67-101.

Paus, A., Velle, G., Larsen, J., Nesje, A. \& Lie, O. 2006. Lateglacial nunataks in central Scandinavia: Biostratigraphical evidence for ice thickness from Lake Flafattjonn, Tynset, Norway. Quaternary Science Reviews, 25 (11-12), 1228-1246.

Pearson, P.N. \& Palmer, M.R. 2000. Atmospheric carbon dioxide concentrations over the past 60 million years. Nature, 406 (6797), 695-699.

Pearson, P.N. \& Palmer, M.R. 2002. The boron isotope approach to paleo-pCO $\mathrm{CO}_{2}$ estimation. Geochimica et Cosmochimica Acta, 66 (15A), A586-A586.

Pekar, S.F., Christie-Blick, N., Kominz, M.A. \& Miller, K.G. 2002. Calibration between eustatic estimates from backstripping and oxygen isotopic records for the Oligocene. Geology, 30 (10), 903-906.

Pelejero, C. \& Calvo, E. 2003. The upper end of the U37K ' temperature calibration revisited. Geochemistry Geophysics Geosystems, 4. 
Peyron, O. \& De Vernal, A. 2001. Application of artificial neural networks (ANN) to highlatitude dinocyst assemblages for the reconstruction of past sea-surface conditions in Arctic and sub-Arctic seas. Journal of Quaternary Science, 16 (7), 699-709.

Pfuhl, H.A. \& McCave, I.N. 2005. Evidence for late Oligocene establishment of the Antarctic Circumpolar Current. Earth and Planetary Science Letters, 235 (3-4), 715-728.

Pilny, J.J., Morgan, A.V. \& Morgan, A. 1987. Paleoclimatic implications of a Late Wisconsinan insect assemblage from Rostock, southwestern Ontario. Canadian Journal of Earth Sciences, 24 (4), 617-630.

Pincivy, A., Malo, M., Ruffet, G., Tremblay, A. \& Sacks, P.E. 2003. Regional metamorphism of the Appalachian Humber zone of Gaspe Peninsula: Ar-40/Ar-39 evidence for crustal thickening during the Taconian orogeny. Canadian Journal of Earth Sciences, 40 (2), 301-315.

Plaut, G., Ghil, M. \& Vautard, R. 1995. Interannual and interdecadal variability in 335 years of Central England Temperatures. Science, 268 (5211), 710-713.

Pochat, S.P., Van Den Driessche, J., Mouton, V. \& Guillocheau, F. 2005. Identification of Permian palaeowind direction from wave-dominated lacustrine sediments (Lodeve Basin, France). Sedimentology, 52 (4), 809-825.

Poole, I., Cantrill, D. \& Utescher, T. 2005. A multi-proxy approach to determine Antarctic terrestrial palaeoclimate during the Late Cretaceous and Early Tertiary. Palaeogeography Palaeoclimatology Palaeoecology, 222 (1-2), 95-121.

Powers, L.A., Werne, J.P., Johnson, T.C., Hopmans, E.C., Damste, J.S.S. \& Schouten, S. 2004. Crenarchaeotal membrane lipids in lake sediments: A new paleotemperature proxy for continental paleoclimate reconstruction? Geology, 32 (7), 613-616.

Prahl, F.G., Muehlhausen, L.A. \& Zahnle, D.L. 1988. Further evaluation of long-chain alkenones as indicators of paleoceanographic conditions. Geochimica et Cosmochimica Acta, 52 (9), 2303-2310, 10.1016/0016-7037(88)90132-9.

Prentice, M.L. \& Krusic, A.G. 2005. Early Pliocene Alpine glaciation in Antarctica: Terrestrial versus tidewater glaciers in Wright Valley. Geografiska Annaler Series aPhysical Geography, 87A (1), 87-109.

Price, G.D. 1999. The evidence and implications of polar ice during the Mesozoic. EarthScience Reviews, 48 (3), 183-210.

Price, G.D., Sellwood, B.W. \& Valdes, P.J. 1995. Sedimentological evaluation of general circulation model simulations for the "greenhouse" earth: Cretaceous and Jurassic. Sedimentary Geology, 100 (1-4), 159-180.

Price, G.D., Valdes, P.J. \& Sellwood, B.W. 1997a. Prediction of modern bauxite occurrence: Implications for climate reconstruction. Palaeogeography Palaeoclimatology Palaeoecology, 131 (1-2), 1-13.

Price, G.D., Valdes, P.J. \& Sellwood, B.W. 1997b. Quantitative palaeoclimate GCM validation: Late Jurassic and mid-Cretaceous case studies. Journal of the Geological Society, 154, 769-772.

Prokoph, A., Ernst, R.E. \& Buchan, K.L. 2004. Time-series analysis of large igneous provinces: 3500 Ma to present. Journal of Geology, 112 (1), 1-22.

Prueher, L.M. \& Rea, D.K. 1998. Rapid onset of glacial conditions in the subarctic North Pacific region at 2.67 Ma: Clues to causality. Geology, 26 (11), 1027-1030.

Qin, X.G., Cai, B.G. \& Liu, T.S. 2005. Loess record of the aerodynamic environment in the east Asia monsoon area since 60,000 years before present. Journal of Geophysical Research-Solid Earth, 110 (B1).

Rae, A.C., Harrison, S., Mighall, T. \& Dawson, A.G. 2004. Periglacial trimlines and nunataks of the Last Glacial Maximum: the Gap of Dunloe, southwest Ireland. Journal of Quaternary Science, 19 (1), 87-97. 
Ragueneau, O., Treguer, P., Leynaert, A., Anderson, R.F., Brzezinski, M.A., DeMaster, D.J., Dugdale, R.C., Dymond, J., Fischer, G., Francois, R., Heinze, C., Maier-Reimer, E., Martin-Jezequel, V., Nelson, D.M. \& Queguiner, B. 2000. A review of the Si cycle in the modern ocean: recent progress and missing gaps in the application of biogenic opal as a paleoproductivity proxy. Global and Planetary Change, 26 (4), 317-365.

Railsback, L.B. 1992. A Geological Numerical-Model for Paleozoic Global Evaporite Deposition. Journal of Geology, 100 (3), 261-277.

Ramirez, J., Mendoza, B., Mendoza, V. \& Adem, J. 2006. Effects of an assumed cosmic raymodulated low global cloud cover on the Earth's temperature. Atmosfera, 19 (3), 169179.

Rampino, M.R. \& Self, S. 1992. Volcanic winter and accelerated glaciation following the Toba super-eruption. Nature, 359 (6390), 50-52.

Ramstein, G., Fluteau, F., Besse, J. \& Joussaume, S. 1997. Effect of orogeny, plate motion and land sea distribution on Eurasian climate change over the past 30 million years. Nature, 386 (6627), 788-795.

Ravelo, A.C. \& Andreasen, D.H. 2000. Enhanced circulation during a warm period. Geophysical Research Letters, 27 (7), 1001-1004.

Ravizza, G., Norris, R.N., Blusztajn, J. \& Aubry, M.P. 2001. An osmium isotope excursion associated with the late Paleocene thermal maximum: evidence of intensified chemical weathering. Paleoceanography, 16 (2), 155-163.

Raymo, M.E. 1991. Geochemical evidence supporting Chamberlin,T.,C. theory of glaciation. Geology, 19 (4), 344-347.

Raymo, M.E., Oppo, D.W. \& Curry, W. 1997. The mid-Pleistocene climate transition: A deep sea carbon isotopic perspective. Paleoceanography, 12 (4), 546-559.

Raymond, A. \& Metz, C. 2004. Ice and its consequences: Glaciation in the Late Ordovician, Late Devonian, Pennsylvanian-Permian, and Cenozoic compared. Journal of Geology, 112 (6), 655-670.

Raymond, P.A. \& Cole, J.J. 2003. Increase in the export of alkalinity from North America's largest river. Science, 301 (5629), 88-91, 10.1126/science.1083788.

Reichow, M.K., Saunders, A.D., White, R.V., Pringle, M.S., Al'Mukhamedov, A.I., Medvedev, A.I. \& Kirda, N.P. 2002. ${ }^{40} \mathrm{Ar} /{ }^{39} \mathrm{Ar}$ dates from the West Siberian Basin: Siberian flood basalt province doubled. Science, 296 (5574), 1846-1849.

Retallack, G.J. 1997. Palaeosols in the upper Narrabeen Group of New South Wales as evidence of early Triassic palaeoenvironments without exact modern analogues. Australian Journal of Earth Sciences, 44 (2), 185-201.

Retallack, G.J. 2001. Soils of the past: an introduction to paleopedology. Blackwell Science, Oxford.

Retallack, G.J. 2002. Carbon dioxide and climate over the past 300 Myr. Philosophical Transactions of the Royal Society of London Series A, 360 (1793), 659-673.

Retallack, G.J. 2005. Pedogenic carbonate proxies for amount and seasonality of precipitation in paleosols. Geology, 33 (4), 333-336.

Retallack, G.J., Veevers, J.J. \& Morante, R. 1996. Global coal gap between Permian-Triassic extinction and Middle Triassic recovery of peat-forming plants. Geological Society of America Bulletin, 108 (2), 195-207.

Reuning, L., Reijmer, J.J.G., Betzler, C., Timmermann, A. \& Steph, S. 2006. SubMilankovitch cycles in periplatform carbonates from the early Pliocene Great Bahama Bank. Paleoceanography, 21 (1).

Rey, O., Simo, J.A. \& Lorente, M.A. 2004. A record of long- and short-term environmental and climatic change during OAE3: La Luna Formation, late Cretaceous (Santonianearly Campanian), Venezuela. Sedimentary Geology, 170 (1-2), 85-105. 
Reynolds, B.C., Frank, M. \& Halliday, A.N. 2006. Silicon isotope fractionation during nutrient utilization in the North Pacific. Earth and Planetary Science Letters, 244 (12), 431-443.

Richards, G.R. 1998. Identifying trends in climate: An application to the Cenozoic. International Journal of Climatology, 18 (6), 583-594.

Rickaby, R.E.M. \& Elderfield, H. 1999. Planktonic foraminiferal Cd/Ca: Paleonutrients or paleotemperature? Paleoceanography, 14 (3), 293-303.

Ridgwell, A. 2005. A Mid Mesozoic Revolution in the regulation of ocean chemistry. Marine Geology, 217 (3-4), 339-357.

Ridley, J.K., Huybrechts, P., Gregory, J.M. \& Lowe, J.A. 2005. Elimination of the Greenland ice sheet in a high CO2 climate. Journal of Climate, 18 (17), 3409-3427.

Riley, T.R., Leat, P.T., Pankhurst, R.J. \& Harris, C. 2001. Origins of large volume rhyolitic volcanism in the Antarctic Peninsula and Patagonia by crustal melting. Journal of Petrology, 42 (6), 1043-1065.

Roberts, D. \& McMinn, A. 1999. A diatom-based palaeosalinity history of Ace Lake, Vestfold Hills, Antarctica. Holocene, 9 (4), 401-408.

Robertson, I., Lucy, D., Baxter, L., Pollard, A.M., Aykroyd, R.G., Barker, A.C., Carter, A.H.C., Switsur, V.R. \& Waterhouse, J.S. 1999. A kernel-based Bayesian approach to climatic reconstruction. Holocene, 9 (4), 495-500.

Robinson, R.S., Sigman, D.M., DiFiore, P.J., Rohde, M.M., Mashiotta, T.A. \& Lea, D.W. 2005. Diatom-bound N-15/N-14: New support for enhanced nutrient consumption in the Ice Age subantarctic. Paleoceanography, 20 (3).

Rodriguez, J. 1999. Use of cenograms in mammalian palaeoecology. A critical review. Lethaia, 32 (4), 331-347.

Rohling, E.J. 2000. Paleosalinity: confidence limits and future applications. Marine Geology, $163(1-4), 1-11$.

Rosales, I., Quesada, S. \& Robles, S. 2004. Paleotemperature variations of Early Jurassic seawater recorded in geochemical trends of belemnites from the Basque-Cantabrian basin, northern Spain. Palaeogeography Palaeoclimatology Palaeoecology, 203 (34), 253-275.

Ross, C.A. \& Ross, J.R.P. 1985. Late Paleozoic depositional sequences are synchronous and worldwide. Geology, 13 (3), 194-197.

Rowe, P.J. \& Maher, B.A. 2000. 'Cold' stage formation of calcrete nodules in the Chinese Loess Plateau: evidence from U-series dating and stable isotope analysis. Palaeogeography Palaeoclimatology Palaeoecology, 157 (1-2), 109-125.

Royer, D.L., Berner, R.A. \& Beerling, D.J. 2001. Phanerozoic atmospheric $\mathrm{CO}_{2}$ change: evaluating geochemical and paleobiological approaches. Earth-Science Reviews, 54 (4), 349-392.

Royer, D.L., Berner, R.A., Montañez, I.P., Tabor, N.J. \& Beerling, D.J. 2004. $\mathrm{CO}_{2}$ as a primary driver of Phanerozoic climate. GSA Today, 14 (3), 4-10, 10.1130/10525173(2004)014<4:CAAPDO >2.0.CO;2.

Rubin, S.I., King, S.L., Jahnke, R.A. \& Froelich, P.N. 2003. Benthic barium and alkalinity fluxes: is $\mathrm{Ba}$ an oceanic paleo-alkalinity proxy for glacial atmospheric $\mathrm{CO} 2$ ? Geophysical Research Letters, 30 (17).

Ruddiman, W.F. \& Kutzbach, J.E. 1991. Plateau uplift and climatic change. Scientific American, 264 (3), 66-\&.

Saltzman, M.R. 2003. Late Paleozoic ice age: oceanic gateway or $\mathrm{pCO}_{2}$ ? Geology, 31 (2), $151-154$.

Saltzman, M.R., Ripperdan, R.L., Brasier, M.D., Lohmann, K.C., Robison, R.A., Chang, W.T., Peng, S.C., Ergaliev, E.K. \& Runnegar, B. 2000. A global carbon isotope 
excursion (SPICE) during the Late Cambrian: relation to trilobite extinctions, organicmatter burial and sea level. Palaeogeography Palaeoclimatology Palaeoecology, 162 (3-4), 211-223.

Samuelsson, J. 1998. Carbon and oxygen isotope geochemistry of Early Neoproterozoic successions on the Kola Peninsula, northwest Russia. Norsk Geologisk Tidsskrift, 78 (4), 291-303.

Santos, J.O.S., Hartmann, L.A., McNaughton, N.J. \& Fletcher, I.R. 2002. Timing of mafic magmatism in the Tapajo's Province (Brazil) and implications for the evolution of the Amazon Craton: evidence from baddeleyite and zircon U-Pb SHRIMP geochronology. Journal of South American Earth Sciences, 15 (4), 409-429.

Sanyal, A., Hemming, N.G., Hanson, G.N. \& Broecker, W.S. 1995. Evidence for a higher pH in the glacial ocean from boron isotopes in foraminifera. Nature, 372 (6511), 234236, 10.1038/373234a0.

Sarnthein, M., Pflaumann, U. \& Weinelt, M. 2003. Past extent of sea ice in the northern North Atlantic inferred from foraminiferal paleotemperature estimates. Paleoceanography, 18 (2).

Schenk, P.E. 1995. Meguma Zone. In: Williams, H. (ed.) Geology of the Appalachian Caledonian Orogen in Canada and Greenland. Geological Survey of Canada, Geology of Canada, 6, 261-277.

Schiller, A., Mikolajewicz, U. \& Voss, R. 1997. The stability of the North Atlantic thermohaline circulation in a coupled ocean-atmosphere general circulation model. Climate Dynamics, 13 (5), 325-347.

Schimel, D.S. 1995. Terrestrial ecosystems and the carbon cycle. Global Change Biology, 1 (1), 77-91.

Schlesinger, W.H. \& Andrews, J.A. 2000. Soil respiration and the global carbon cycle. Biogeochemistry, 48 (1), 7-20.

Schmidt, G.A. 1999. Error analysis of paleosalinity calculations. Paleoceanography, 14 (3), 422-429.

Schmieder, F., von Dobeneck, T. \& Bleil, U. 2000. The Mid-Pleistocene climate transition as documented in the deep South Atlantic Ocean: initiation, interim state and terminal event. Earth and Planetary Science Letters, 179 (3-4), 539-549.

Schneider, S.H. \& Dickinson, R.E. 1974. Climate modeling. Reviews of Geophysics, 12 (3), 447-493.

Schopka, H.H., Gudmundsson, M.T. \& Tuffen, H. 2006. The formation of Helgafell, southwest Iceland a monogenetic subglacial hyaloclastite ridge: sedimentology, volcano-ice interaction hydrology and volcano-ice interaction. Journal of Volcanology and Geothermal Research, 152 (3-4), 359-377.

Schouten, S., Hopmans, E.C. \& Damste, J.S.S. 2004. The effect of maturity and depositional redox conditions on archaeal tetraether lipid palaeothermometry. Organic Geochemistry, 35 (5), 567-571.

Schouten, S., Hopmans, E.C., Forster, A., van Breugel, Y., Kuypers, M.M.M. \& Damste, J.S.S. 2003. Extremely high sea-surface temperatures at low latitudes during the middle Cretaceous as revealed by archaeal membrane lipids. Geology, 31 (12), 10691072.

Schouten, S., Hopmans, E.C., Schefuss, E. \& Damste, J.S.S. 2002. Distributional variations in marine crenarchaeotal membrane lipids: a new tool for reconstructing ancient sea water temperatures? Earth and Planetary Science Letters, 204 (1-2), 265-274.

Schouten, S., Ossebaar, J., Schreiber, K., Kienhuis, M.V.M., Langer, G., Benthien, A. \& Bijma, J. 2006. The effect of temperature, salinity and growth rate on the stable 
hydrogen isotopic composition of long chain alkenones produced by Emiliania huxleyi and Gephyrocapsa oceanica. Biogeosciences, 3 (1), 113-119.

Schouten, S., Van Kaam-Peters, H.M.E., Rijpstra, W.I.C., Schoell, M. \& Damste, J.S.S. 2000. Effects of an oceanic anoxic event on the stable carbon isotopic composition of Early Toarcian carbon. American Journal of Science, 300 (1), 1-22.

Schwalb, A. 2003. Lacustrine ostracodes as stable isotope recorders of late-glacial and Holocene environmental dynamics and climate. Journal of Paleolimnology, 29 (3), 267-351.

Scott, A.C. 1989. Observations on the nature and origin of fusain. International Journal of Coal Geology, 12 (1-4), 443-475.

Scott, A.C. 2000. The Pre-Quaternary history of fire. Palaeogeography Palaeoclimatology Palaeoecology, 164 (1-4), 281-329.

Scott, A.C., Lomax, B.H., Collinson, M.E., Upchurch, G.R. \& Beerling, D.J. 2000. Fire across the K-T boundary: initial results from the Sugarite Coal, New Mexico, USA. Palaeogeography Palaeoclimatology Palaeoecology, 164 (1-4), 381-395.

Segalen, L., Rognon, P., Pickford, M., Senut, B., Emmanuel, L., Renard, M. \& Ward, J. 2004. Reconstitution of dune morphologies and palaeowind regimes in the ProtoNamib since the Miocene. Bulletin de la Société Géologique de France, 175 (6), $537-$ 546.

Sejrup, H.P., Birks, H.J.B., Kristensen, D.K. \& Madsen, H. 2004. Benthonic foraminiferal distributions and quantitative transfer functions for the northwest European continental margin. Marine Micropaleontology, 53 (1-2), 197-226.

Sellwood, B.W., Price, G.D., Shackleton, N.J. \& Francis, J.E. 1993. Sedimentary facies as indicators of Mesozoic palaeoclimate [and discussion]. Philosophical Transactions of the Royal Society of London Series B-Biological Sciences, 341 (1297), 225-233.

Sellwood, B.W. \& Valdes, P.J. 1997. Geological evaluation of climate general circulation models and model implications for Mesozoic cloud cover. Terra Nova, 9 (2), 75-78.

Sellwood, B.W., Valdes, P.J. \& Price, G.D. 2000. Geological evaluation of multiple general circulation model simulations of Late Jurassic palaeoclimate. Palaeogeography Palaeoclimatology Palaeoecology, 156 (1-2), 147-160.

Shackleton, N.J. 1965. The high-precision isotopic analysis of oxygen and carbon in carbon dioxide. Journal of Scientific Instruments, 42 (9), 689-692, 10.1088/09507671/42/9/306.

Shackleton, N.J. 1977. Oxygen isotope stratigraphic record of the Late Pleistocene. Philosophical Transactions of the Royal Society of London Series B-Biological Sciences, 280 (972), 169-182.

Shackleton, N.J. \& Kennett, J.P. 1975. Late Cenozoic oxygen and carbon isotopic changes at DSDP site 284: implication for glacial history of the Northern Hemisphere and Antarctica. Initial Reports of the Deep Sea Drilling Program, 29, 801-807.

Shackleton, N.J. \& Opdyke, N.D. 1973. Oxygen isotope and paleomagnetic stratigraphy of Equatorial Pacific core V28-238: oxygen isotope temperatures and ice volumes on a $10^{5}$ and $10^{6}$ year scale. Quaternary Research, 3, 39-55.

Shaviv, N.J. 2005. On the link between cosmic rays and terrestrial climate. International Journal of Modern Physics A, 20 (29), 6662-6665.

Shaviv, N.J. \& Veizer, J. 2003. Celestial driver of Phanerozoic climate? GSA Today, 13 (7), 4-10.

Sherlock, S.C., Kelley, S.P., Zalasiewicz, J.A., Schofield, D.I., Evans, J.A., Merriman, R.J. \& Kemp, S.J. 2003. Precise dating of low-temperature deformation: Strain-fringe analysis by Ar-40-Ar-39 laser microprobe. Geology, 31 (3), 219-222. 
Siegenthaler, U., Stocker, T.F., Monnin, E., Luthi, D., Schwander, J., Stauffer, B., Raynaud, D., Barnola, J.M., Fischer, H., Masson-Delmotte, V. \& Jouzel, J. 2005. Stable carbon cycle-climate relationship during the late Pleistocene. Science, 310 (5752), 13131317.

Siesser, W.G. 1995. Paleoproductivity of the Indian Ocean during the Tertiary period. Global and Planetary Change, 11 (1-2), 71-88.

Sigman, D.M. 2000. Global carbon cycle and its links to carbon fixation by oceanic phytoplankton. Abstracts of Papers of the American Chemical Society, 219, U839U839.

Sigman, D.M., Altabet, M.A., Francois, R. \& Whelan, J. 1997. Diatom microfossil N isotopes support the hypothesis of higher nitrate utilization in the Southern Ocean during the last ice age. Abstracts of Papers of the American Chemical Society, 214, 69-GEOC.

Sigman, D.M., Jaccard, S.L. \& Haug, G.H. 2004. Polar ocean stratification in a cold climate. Nature, 428 (6978), 59-63.

Sikes, E.L. \& Sicre, M.A. 2002. Relationship of the tetra-unsaturated C-37 alkenone to salinity and temperature: Implications for paleoproxy applications. Geochemistry Geophysics Geosystems, 3.

Sime, N.G., De La Rocha, C.L. \& Galy, A. 2005. Negligible temperature dependence of calcium isotope fractionation in 12 species of planktonic foraminifera. Earth and Planetary Science Letters, 232 (1-2), 51-66.

Simkevicius, P., Ahlberg, A. \& Grigelis, A. 2003. Jurassic smectite and kaolinite trends of the East European Platform: implications for palaeobathymetry and palaeoclimate. Terra Nova, 15 (4), 225-229.

Sluijs, A., Schouten, S., Pagani, M., Woltering, M., Brinkhuis, H., Damsté, J.S.S., Dickens, G.R., Huber, M., Reichart, G.-J., Stein, R., Matthiessen, J., Lourens, L.J., Pedentchouk, N., Backman, J., Moran, K. \& Expedition 302 Scientists 2006. Subtropical Arctic Ocean temperatures during the Palaeocene/Eocene thermal maximum. Nature, 441, 610-613, 10.1038/nature04668.

Smellie, J.L. 2000. Subglacial eruptions. In: Sigurdsson, H. (ed.) Encyclopaedia of Volcanoes. Academic Press, San Diego, 403-418.

Smellie, J.L., McIntosh, W.C. \& Esser, R. 2006. Eruptive environment of volcanism on Brabant Island: Evidence for thin wet-based ice in northern Antarctic Peninsula during the Late Quaternary. Palaeogeography Palaeoclimatology Palaeoecology, 231 $(1-2), 233-252$.

Smellie, J.L. \& Skilling, I.P. 1994. Products of subglacial volcanic eruptions under different ice thicknesses: Two examples from Antarctica. Sedimentary Geology, 91 (1-4), 115129.

Smith, A.G. \& Pickering, K.T. 2003. Oceanic gateways as a critical factor to initiate icehouse Earth. Journal of the Geological Society, London, 160 (3), 337-340.

Smith, A.J. 1963. A striated pavement beneath the basal Gondwana sediments on the Ajay River, Bihar, India. Nature, 198, 880, 10.1038/198880b0.

Snyder, P.K., Delire, C. \& Foley, J.A. 2004. Evaluating the influence of different vegetation biomes on the global climate. Climate Dynamics, 23 (3-4), 279-302.

Sobolev, S.V. \& Babeyko, A.Y. 2005. What drives orogeny in the Andes? Geology, 33 (8), $617-620$.

Solanki, S.K. \& Krivova, N.A. 2004. Solar irradiance variations: From current measurements to long-term estimates. Solar Physics, 224 (1), 197-208.

Solanki, S.K., Usoskin, I.G., Kromer, B., Schussler, M. \& Beer, J. 2004. Unusual activity of the Sun during recent decades compared to the previous 11,000 years. Nature, 431 (7012), 1084-1087. 
Spicer, R.A., Herman, A.B. \& Kennedy, E.M. 2005. The sensitivity of CLAMP to taphonomic loss of foliar physiognomic characters. Palaios, 20 (5), 429-438.

Stanley, E.A. 1970. Maastrichtian plant microfossil assemblages and their paleogeographic and paleoclimatic implications for latest Mesozoic time. American Association of Petroleum Geologists Bulletin, 54 (12), 2506-\&.

Staub, J.R. 2002. Marine flooding events and coal bed sequence architecture in southern West Virginia. International Journal of Coal Geology, 49 (2-3), 123-145.

Stiles, C.A., Mora, C.I. \& Driese, S.G. 2001. Pedogenic iron-manganese nodules in Vertisols: A new proxy for paleoprecipitation? Geology, 29 (10), 943-946.

Stocker, T.F., Wright, D.G. \& Mysak, L.A. 1992. A zonally averaged, coupled oceanatmosphere model for paleoclimate studies. Journal of Climate, 5 (8), 773-797.

Stoll, H.M. \& Schrag, D.P. 1996. Evidence for glacial control of rapid sea level changes in the Early Cretaceous. Science, 272 (5269), 1771-1774.

Strauss, H. \& Peters-Kottig, W. 2003. The Paleozoic to Mesozoic carbon cycle revisited: the carbon isotopic composition of terrestrial organic matter. Geochemistry Geophysics Geosystems, 4 (10), 1-15, 1083, 10.1029/2003GC000555.

Streel, M., Caputo, M.V., Loboziak, S. \& Melo, J.H.G. 2000. Late Frasnian-Famennian climates based on palynomorph analyses and the question of the Late Devonian glaciations. Earth-Science Reviews, 52 (1-3), 121-173.

Sun, D.H., Bloemendal, J., Rea, D.K., An, Z.S., Vandenberghe, J., Lu, H.Y., Su, R.X. \& Liu, T.S. 2004. Bimodal grain-size distribution of Chinese loess, and its palaeoclimatic implications. Catena, 55 (3), 325-340.

Sun, Y.B. \& An, Z.S. 2005. Late Pliocene-Pleistocene changes in mass accumulation rates of eolian deposits on the central Chinese Loess Plateau. Journal of Geophysical Research-Atmospheres, 110 (D23).

Swainson, I.P. \& Hammond, R.P. 2001. Ikaite, CaCO3 center dot 6H(2)O: Cold comfort for glendonites as paleothermometers. American Mineralogist, 86 (11-12), 1530-1533.

Texier, D., de Noblet, N., Harrison, S.P., Haxeltine, A., Jolly, D., Joussaume, S., Laarif, F., Prentice, I.C. \& Tarasov, P. 1997. Quantifying the role of biosphere-atmosphere feedbacks in climate change: coupled model simulations for 6000 years BP and comparison with palaeodata for northern Eurasia and northern Africa. Climate Dynamics, 13 (12), 865-882.

Thiry, M. 2000. Palaeoclimatic interpretation of clay minerals in marine deposits: an outlook from the continental origin. Earth-Science Reviews, 49 (1-4), 201-221.

Thomas, D.J., Zachos, J.C., Bralower, T.J., Thomas, E. \& Bohaty, S. 2002a. Warming the fuel for the fire: Evidence for the thermal dissociation of methane hydrate during the Paleocene-Eocene thermal maximum. Geology, 30 (12), 1067-1070.

Thomas, R.J., Chevallier, L.P., Gresse, P.G., Harmer, R.E., Eglington, B.M., Armstrong, R.A., de Beer, C.H., Martini, J.E.J., de Kock, G.S., Macey, P.H. \& Ingram, B.A. 2002b. Precambrian evolution of the Sirwa Window, Anti-Atlas Orogen, Morocco. Precambrian Research, 118 (1-2), 1-57.

Thorn, V.C. \& DeConto, R. 2006. Antarctic climate at the Eocene/Oligocene boundary climate model sensitivity to high latitude vegetation type and comparisons with the palaeobotanical record. Palaeogeography Palaeoclimatology Palaeoecology, 231 (12), 134-157.

Tobin, K.J. \& Walker, K.R. 1997. Ordovician oxygen isotopes and paleotemperatures. Palaeogeography Palaeoclimatology Palaeoecology, 129 (3-4), 269-290.

Tripati, A., Backman, J., Elderfield, H. \& Ferretti, P. 2005. Eocene bipolar glaciation associated with global carbon cycle changes. Nature, 436 (7049), 341-346. 
Tyndall, J. 1861. On the absorption and radiation of heat by gases and vapours, and on the physical connection of radiation, absorption, and conduction. Philosophical Magazine Series 4, 22, 169-94, 273-285.

Tziperman, E. \& Gildor, H. 2003. On the mid-Pleistocene transition to 100-kyr glacial cycles and the asymmetry between glaciation and deglaciation times. Paleoceanography, 18 $(1)$.

Ullyott, J.S. \& Nash, D.J. 2006. Micromorphology and geochemistry of groundwater silcretes in the eastern South Downs, UK. Sedimentology, 53 (2), 387-412.

Urey, H.C. 1947. The thermodynamic properties of isotopic substances. Journal of the Chemical Society, 1947, 562-581, 10.1039/JR9470000562.

Usoskin, I.G., Schussler, M., Solanki, S.K. \& Mursula, K. 2005. Solar activity, cosmic rays, and Earth's temperature: A millennium-scale comparison. Journal of Geophysical Research-Space Physics, 110 (A10).

Valdes, P.J. \& Sellwood, B.W. 1992. A paleoclimate model for the Kimmeridgian. Palaeogeography Palaeoclimatology Palaeoecology, 95 (1-2), 47-72.

van de Flierdt, T., Frank, M., Lee, D.C. \& Halliday, A.N. 2002. Glacial weathering and the hafnium isotope composition of seawater. Earth and Planetary Science Letters, 198 (1-2), 167-175.

van de Schootbrugge, B., McArthur, J.M., Bailey, T.R., Rosenthal, Y., Wright, J.D. \& Miller, K.G. 2005. Toarcian oceanic anoxic event: An assessment of global causes using belemnite $\mathrm{C}$ isotope records. Paleoceanography, 20 (3).

Van Houten, F.B. 1961. Climatic significance of red beds. In: Nairn, A.E.M. (ed.) Descriptive palaeoclimatology. Interscience, New York, 89-139.

Van Niekerk, H.S., Beukes, N.J. \& Gutzmer, J. 1999. Post-Gondwana pedogenic ferromanganese deposits, ancient soil profiles, African land surfaces and palaeoclimatic change on the Highveld of South Africa. Journal of African Earth Sciences, 29 (4), 761-781.

Vance, D. \& Burton, K. 1999. Neodymium isotopes in planktonic foraminifera: a record of the response of continental weathering and ocean circulation rates to climate change. Earth and Planetary Science Letters, 173 (4), 365-379, 10.1016/S0012821X(99)00244-7.

Vaughan, A.P.M. \& Livermore, R.A. 2005. Episodicity of Mesozoic terrane accretion along the Pacific margin of Gondwana: implications for superplume-plate interactions. In: Vaughan, A.P.M., Leat, P.T. \& Pankhurst, R.J. (eds) Terrane Processes at the Margins of Gondwana. Geological Society, London, Special Publication, 246, 143178.

Vaughan, A.P.M. \& Scarrow, J.H. 2003. Ophiolite obduction pulses as a proxy indicator of superplume events? Earth and Planetary Science Letters, 213 (3-4), 407-416.

Vaughan, A.P.M. \& Storey, B.C. in press. A new supercontinent self-destruct mechanism: evidence from the Late Triassic-Early Jurassic. Journal of the Geological Society, London.

Vecoli, M. \& Le Herisse, A. 2004. Biostratigraphy, taxonomic diversity and patterns of morphological evolution of Ordovician acritarchs (organic-walled microphytoplankton) from the northern Gondwana margin in relation to palaeoclimatic and palaeogeographic changes. Earth-Science Reviews, 67 (3-4), 267311.

Veevers, J.J. 2004. Gondwanaland from 650-500 Ma assembly through 320 Ma merger in Pangea to 185-100 Ma breakup: supercontinental tectonics via stratigraphy and radiometric dating. Earth Science Reviews, 68, 1-132, 10.1016/j.earscirev.2004.05.002. 
Veevers, J.J. \& Powell, C.M. 1987. Late Paleozoic glacial episodes in Gondwanaland reflected in transgressive-regressive depositional sequences in Euramerica. Geological Society of America Bulletin, 98 (4), 475-487.

Vengosh, A., Kolodny, Y., Starinsky, A., Chivas, A.R. \& McCulloch, M.T. 1991. Coprecipitation and isotopic fractionation of boron in modern biogenic carbonates. Geochimica et Cosmochimica Acta, 55 (10), 2901-2910.

Via, R.K. \& Thomas, D.J. 2006. Evolution of Atlantic thermohaline circulation: Early Oligocene onset of deep-water production in the North Atlantic. Geology, 34 (6), 441-444, 10.1130/G22545.1.

Vidal, L., Bickert, T., Wefer, G. \& Rohl, U. 2002. Late miocene stable isotope stratigraphy of SE Atlantic ODP Site 1085: Relation to Messinian events. Marine Geology, 180 (14), 71-85.

Villa, G. \& Persico, D. 2006. Late Oligocene climatic changes: Evidence from calcareous nannofossils at Kerguelen Plateau Site 748 (Southern ocean). Palaeogeography Palaeoclimatology Palaeoecology, 231 (1-2), 110-119.

Visser, J.N.J. 1997. Deglaciation sequences in the Permo-Carboniferous Karoo and Kalahari basins of southern Africa: A tool in the analysis of cyclic glaciomarine basin fills. Sedimentology, 44 (3), 507-521.

von der Heydt, A. \& Dijkstra, H.A. 2006. Effect of ocean gateways on the global ocean circulation in the late Oligocene and early Miocene. Paleoceanography, 21 (1).

vonBlanckenburg, F., Onions, R.K., Belshaw, N.S., Gibb, A. \& Hein, J.R. 1996. Global distribution of beryllium isotopes in deep ocean water as derived from Fe-Mn crusts. Earth and Planetary Science Letters, 141 (1-4), 213-226.

Wade, B.S. \& Palike, H. 2004. Oligocene climate dynamics. Paleoceanography, 19 (4).

Walker, I.R. 1991. Modern Assemblages of Arctic and Alpine Chironomidae as Analogs for Late-Glacial Communities. Hydrobiologia, 214, 223-227.

Walker, J.C.G., Hays, P.B. \& Kasting, J.F. 1981. A negative feedback mechanism for the long-term stabilization of Earth's surface-temperature. Journal of Geophysical Research-Oceans and Atmospheres, 86 (NC10), 9776-9782.

Walliser, O.H. 1995. Global events and event stratigraphy in the Phanerozoic. SpringerVerlag, Berlin.

Wallmann, K. 2001. The geological water cycle and the evolution of marine delta O-18 values. Geochimica et Cosmochimica Acta, 65 (15), 2469-2485.

Wallmann, K. 2004. Impact of atmospheric $\mathrm{CO} 2$ and galactic cosmic radiation on Phanerozoic climate change and the marine delta O-18 record. Geochemistry Geophysics Geosystems, 5.

Wang, P.X., Tian, J., Cheng, X.R., Liu, C.L. \& Xu, J. 2004. Major Pleistocene stages in a carbon perspective: The South China Sea record and its global comparison. Paleoceanography, 19 (4).

Wang, Y.D., Mosbrugger, V. \& Zhang, H. 2005. Early to Middle Jurassic vegetation and climatic events in the Qaidam Basin, northwest China. Palaeogeography Palaeoclimatology Palaeoecology, 224 (1-3), 200-216.

Warne, M.T. 2005. The global Mio-Pliocene climatic equability and coastal ostracod faunas of southeast Australia. Palaeogeography Palaeoclimatology Palaeoecology, 225 (14), 248-265.

Webb, J.A. \& Golding, S.D. 1998. Geochemical mass-balance and oxygen-isotope constraints on silcrete formation and its paleoclimatic implications in Southern Australia. Journal of Sedimentary Research, 68 (5), 981-993. 
Wefer, G., Berger, W.H., Bijma, J. \& Fischer, G. 1999. Clues to ocean history: a brief overview of proxies. In: Fischer, G. \& Wefer, G. (eds) Use of proxies in paleoceanography: examples from the South Atlantic. Springer, Berlin, 1-68.

Wei, G.J., Yu, K.F. \& Zhao, J.X. 2004. Sea surface temperature variations recorded on coralline $\mathrm{Sr} / \mathrm{Ca}$ ratios during Mid-Late Holocene in Leizhou Peninsula. Chinese Science Bulletin, 49 (17), 1876-1881.

Wendler, J. 2004. External forcing of the geomagnetic field? Implications for the cosmic ray flux - climate variability. Journal of Atmospheric and Solar-Terrestrial Physics, 66 (13-14), 1195-1203.

Wenzel, B., Lecuyer, C. \& Joachimski, M.M. 2000. Comparing oxygen isotope records of Silurian calcite and phosphate - delta O-18 compositions of brachiopods and conodonts. Geochimica et Cosmochimica Acta, 64 (11), 1859-1872.

Westerhold, T., Bickert, T. \& Rohl, U. 2005. Middle to late Miocene oxygen isotope stratigraphy of ODP site 1085 (SE Atlantic): new constraints on Miocene climate variability and sea-level fluctuations. Palaeogeography Palaeoclimatology Palaeoecology, 217 (3-4), 205-222.

Westerlund, K.J., Gurney, J.J., Carlson, R.W., Shirey, S.B., Hauri, E.H. \& Richardson, S.H. 2004. A metasomatic origin for late Archean eclogitic diamonds: implications from internal morphology of diamonds and $\mathrm{Re}-\mathrm{Os}$ and $\mathrm{S}$ isotope characteristics of their sulfide inclusions from the late Jurassic Klipspringer kimberlites. South African Journal of Geology, 107 (1-2), 119-130.

Wignall, P.B. 2001. Large igneous provinces and mass extinctions. Earth-Science Reviews, $53(1-2), 1-33$.

Wignall, P.B., Newton, R.J. \& Little, C.T.S. 2005. The timing of paleoenvironmental change and cause-and-effect relationships during the early Jurassic mass extinction in Europe. American Journal of Science, 305 (10), 1014-1032.

Wilde, P., Lyons, T.W. \& Quinby-Hunt, M.S. 2004. Organic carbon proxies in black shales: molybdenum. Chemical Geology, 206 (3-4), 167-176.

Williams, G.E. 1998. Late Neoproterozoic periglacial aeolian sand sheet, Stuart Shelf, South Australia. Australian Journal of Earth Sciences, 45 (5), 733-741.

Williams, M., Haywood, A.M., Taylor, S.P., Valdes, P.J., Sellwood, B.W. \& Hillenbrand, C.D. 2005. Evaluating the efficacy of planktonic foraminifer calcite delta O-18 data for sea surface temperature reconstruction for the Late Miocene. Geobios, 38 (6), 843-863.

Williams, N.E. \& Eyles, N. 1995. Sedimentary and Paleoclimatic Controls on Caddisfly (Insecta, Trichoptera) Assemblages During the Last Interglacial-to-Glacial Transition in Southern Ontario. Quaternary Research, 43 (1), 90-105.

Wilson, P.A., Norris, R.D. \& Cooper, M.J. 2002. Testing the Cretaceous greenhouse hypothesis using glassy foraminiferal calcite from the core of the Turonian tropics on Demerara Rise. Geology, 30 (7), 607-610.

Winckler, G., Anderson, R.F., Stute, M. \& Schlosser, P. 2004. Does interplanetary dust control 100 kyr glacial cycles? Quaternary Science Reviews, 23 (18-19), 1873-1878.

Wing, S.L., Bao, H. \& Koch, P.L. 2000. An early Eocene cool period? Evidence for continental cooling during the warmest part of the Cenozoic. In: Huber, B.T., MacLeod, K.S. \& Wing, S.C. (eds) Warm Climates in Earth History. Cambridge University Press, Cambridge, 197-237.

Wing, S.L. \& Greenwood, D.R. 1993. Fossils and fossil climate: the case for equable continental interiors in the Eocene. Philosophical Transactions of the Royal Society of London Series B-Biological Sciences, 341 (1297), 243-252. 
Winguth, A.M.E. \& Maier-Reimer, E. 2005. Causes of the marine productivity and oxygen changes associated with the Permian-Triassic boundary: A reevaluation with ocean general circulation models. Marine Geology, 217 (3-4), 283-304.

Winograd, I.J., Coplen, T.B., Landwehr, J.M., Riggs, A.C., Ludwig, K.R., Szabo, B.J., Kolesar, P.T. \& Revesz, K.M. 1992. Continuous 500,000-year climate record from vein calcite in Devils Hole, Nevada. Science, 258 (5080), 255-260.

Wolfe, J.A. 1993. A method of obtaining climatic parameters from leaf assemblages. US Geological Survey Bulletin, 2040, 1-73.

Woodcock, D.W. 1992. Climate reconstruction based on biological indicators. Quarterly Review of Biology, 67 (4), 457-477.

Woodward, F.I. 1987. Stomatal numbers are sensitive to increases in $\mathrm{CO}_{2}$ from pre-industrial levels. Nature, 327 (6123), 617-618.

Woodward, F.I. \& Bazzaz, F.A. 1988. The responses of stomatal density to $\mathrm{CO}_{2}$ partialpressure. Journal of Experimental Botany, 39 (209), 1771-1781.

Wuchter, C., Schouten, S., Coolen, M.J.L. \& Damste, J.S.S. 2004. Temperature-dependent variation in the distribution of tetraether membrane lipids of marine Crenarchaeota: Implications for TEX86 paleothermometry. Paleoceanography, 19 (4).

Yamada, K., Tanaka, Y. \& Irizuki, T. 2005. Paleoceanographic shifts and global events recorded in late Pliocene shallow marine deposits (2.80-2.55 Ma) of the Sea of Japan. Palaeogeography Palaeoclimatology Palaeoecology, 220 (3-4), 255-271.

Yemane, K. \& Kelts, K. 1996. Isotope geochemistry of Upper Permian early diagenetic calcite concretions: Implications for Late Permian waters and surface temperatures in continental Gondwana. Palaeogeography Palaeoclimatology Palaeoecology, 125 (14), 51-73.

Young, G.M., von Brunn, V., Gold, D.J.C. \& Minter, W.E.L. 1998. Earth's oldest reported glaciation: Physical and chemical evidence from the Archean Mozaan Group (similar to $2.9 \mathrm{Ga}$ ) of South Africa. Journal of Geology, 106 (5), 523-538.

$\mathrm{Yu}$, F.Q. 2002. Altitude variations of cosmic ray induced production of aerosols: Implications for global cloudiness and climate. Journal of Geophysical Research-Space Physics, 107 (A7).

Zachos, J., Pagani, M., Sloan, L., Thomas, E. \& Billups, K. 2001. Trends, rhythms, and aberrations in global climate $65 \mathrm{Ma}$ to present. Science, 292 (5517), 686-693.

Zachos, J.C. \& Kump, L.R. 2005. Carbon cycle feedbacks and the initiation of Antarctic glaciation in the earliest Oligocene. Global and Planetary Change, 47 (1), 51-66.

Zachos, J.C., Lohmann, K.C., Walker, J.C.G. \& Wise, S.W. 1993. Abrupt climate change and transient climates during the Paleogene: a marine perspective. Journal of Geology, 101 (2), 191-213.

Zachos, J.C., Rohl, U., Schellenberg, S.A., Sluijs, A., Hodell, D.A., Kelly, D.C., Thomas, E., Nicolo, M., Raffi, I., Lourens, L.J., McCarren, H. \& Kroon, D. 2005. Rapid acidification of the ocean during the Paleocene-Eocene thermal maximum. Science, 308 (5728), 1611-1615.

Zeebe, R.E. 2005. Stable boron isotope fractionation between dissolved $\mathrm{B}(\mathrm{OH})(3)$ and $\mathrm{B}(\mathrm{OH})(4)(-)$. Geochimica et Cosmochimica Acta, 69 (11), 2753-2766.

Zhang, Y., Obata, H. \& Nozaki, Y. 2004. Silver in the Pacific Ocean and the Bering Sea. Geochemical Journal, 38 (6), 623-633.

Zharkov, M.A. 2005. Evaporite sedimentation in the Precambrian as related to changes in biosphere and seawater chemistry, article 1: evaporites of the Archean and lower Proterozoic. Stratigraphy and Geological Correlation, 13 (2), 134-142.

Zhu, X.K., Guo, Y., Williams, R.J.P., O'Nions, R.K., Matthews, A., Belshaw, N.S., Canters, G.W., de Waal, E.C., Weser, U., Burgess, B.K. \& Salvato, B. 2002. Mass 
fractionation processes of transition metal isotopes. Earth and Planetary Science Letters, 200 (1-2), 47-62.

Zhu, X.K., O'Nions, R.K., Guo, Y.L. \& Reynolds, B.C. 2000. Secular variation of iron isotopes in North Atlantic Deep Water. Science, 287 (5460), 2000-2002.

Ziegler, A.M., Eshel, G., Rees, P.M., Rothfus, T.A., Rowley, D.B. \& Sunderlin, D. 2003.

Tracing the tropics across land and sea: Permian to present. Lethaia, 36 (3), 227-254.

Zielinski, U., Gersonde, R., Sieger, R. \& Futterer, D. 1998. Quaternary surface water temperature estimations: Calibration of a diatom transfer function for the Southern Ocean. Paleoceanography, 13 (4), 365-383. 


\section{Figure Captions}

Figure 1: (a) Late Neoproterozoic and Phanerozoic climate modes of Frakes et al. (1992) from Table 1; (b) Intervals of glacial or cool (grey bars) and warm (white areas or bars) climates for the Late Neoproterozoic and Phanerozoic, modified from fig. $2 \mathrm{~b}$ of Royer et al. (2004) including additional intervals as discussed in the text and listed in Table 1, with the Palaeozoic-Recent palaeotemperature curve of Royer et al. (2004) based on $\delta^{18} \mathrm{O}$ calibrated with palaeo-pH based on $\mathrm{CO}_{2}$ proxies and palaeo-concentrations of $\mathrm{Ca}$ in seawater; cool intervals labelled c1-c29 (Table 1); warm intervals labelled w1-w5 (Table 1). Brackets above Fig. $1 \mathrm{~b}$ indicate the durations of high- and low- $\mathrm{CO}_{2}$ modes for Phanerozoic climate as discussed in the text and listed in Table 1.

Figure 2: HadCM3 coupled ocean-atmosphere GCM prediction showing the difference in December, January and February (DJF) \& June, July and August (JJA) surface temperatures $\left({ }^{\circ} \mathrm{C}\right)$ between a Mid Pliocene ( 3 Ma BP) and pre-industrial experiment (redrawn from Haywood et al. in press).

Figure 3: (a) Palaeo-CO2 atmospheric concentration as a multiple 'R' of pre-industrial values using the curve of Berner (2003a) superimposed on the climate modes of Frakes et al. (1992); (b) Intervals of glacial or cool (black bars) and warm (white areas) climates and durations of high- and low- $\mathrm{CO}_{2}$ modes for the Late Neoproterozoic and Phanerozoic modified from Fig. $1 \mathrm{~b}$ shown for reference.

Figure 4: Fig. 1a superimposed with (a) late Neoproterozoic and Phanerozoic tectonic events modified after Vaughan \& Livermore (2005) fig. 3; except age of Rodinia break-up (Murphy et al. 2004), Pan-African events (Thomas et al. 2002b; Heilbron \& Machado 2003; Meert 
2003), Ross-Delamerian (Boger \& Miller 2004), Grampian/Taconian (Pincivy et al. 2003; Dewey 2005), Scandian (Kirkland et al. 2006) and Acadian (Sherlock et al. 2003); (b) Intervals of glacial or cool (black bars) and warm (white areas) climates and durations of high- and low- $\mathrm{CO}_{2}$ modes for the Late Neoproterozoic and Phanerozoic modified from Fig. 1b shown for reference; (c) Phanerozoic intervals of "calcite" and "aragonite" seas for the Phanerozoic as suggested by Hardie (1996).

Figure 5: Reconstruction of Cenozoic opening of the Drake Passage and Tasman oceanic gateways and onset of the circum-Antarctic current (Redrawn after Kennett 1977).

Figure 6: (a) Fig 1b intervals of glacial or cool (grey bars) and warm (white areas or bars) climates for the Late Neoproterozoic and Phanerozoic overlain by the timing, and approximate, estimated areas of large igneous province flood basalt events (including Gondwana rhyolite magmatism; duration from Riley et al. (2001)) for the Neoproterozoic to Neogene modified from Ernst \& Buchan (2001) and on-line database at http://www.largeigneousprovinces.org/downloads.html (accessed 9/7/2006), except Ethiopia (Kieffer et al. 2004), North Atlantic volcanic province (Eldholm \& Grue 1994), Bunbury Basalts (Ingle et al. 2004), CAMP (McHone 2002), Nilufer unit (Genc 2004), Brazil (Santos et al. 2002) and Kalkarindji LIP (Glass \& Phillips 2006); Gondwana rhyolite magmatism shown as horizontal grey bar; (b) data as for (a) but showing large igneous province volumes instead. Names of continental flood basalts indicated in plain type; oceanic flood basalts indicated in italic type. Gradationally shaded area shows geological interval over which sea floor is preserved. 
Figure 7: Fig 1b intervals of glacial or cool (grey bars) and warm (white areas or bars) climates for the Late Neoproterozoic and Phanerozoic overlain by (a) Cumulative frequency plot (Ludwig 1999) of Phanerozoic ophiolite obduction events modified from Vaughan \& Scarrow (2003) (b) (Cumulative frequency plot (Ludwig 1999) of Phanerozoic kimberlite age data replotted from Griffin et al. (1999), Heaman \& Kjarsgaard (2000), Belousova et al. (2001), Davis \& Miller (2001), Heaman et al. (2003), Westerlund et al. (2004), and Jelsma et al. (2004).

Figure 8: (a) Fig. 1a superimposed with intervals of high galactic cosmic ray flux for the Phanerozoic from Wallmann (2004); (b) Intervals of glacial or cool (black bars) and warm (white areas) climates and durations of high- and low- $\mathrm{CO}_{2}$ modes for the Late Neoproterozoic and Phanerozoic modified from Fig. 1b shown for reference. 
Table 1: Climate modes and periods of contrasting climate for the Phanerozoic

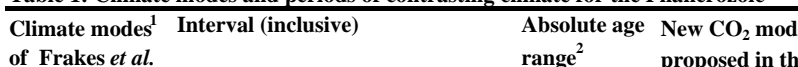

of Frakes et al.

(1992)

Interval (inclusive)

Absolute age range ${ }^{2}$ Intervals of contrasting climate $e^{4}$

Warm

Ediacaran to Late Ordovician

Warm,
fluctuating

Ediacaran-Visean (late Early Carboniferous)

600-326.4 Ma

mid-Ediacaran (c1)

$580 \mathrm{Ma}$

Steptoan (mid-Late Cambrian) (c2)

Tremadocian (Early Ordovician) (c3)

(Late Ordovician) (c5)

$455 \mathrm{Ma}$

late Katian stage, Early Ashgill (Late Ordovician) (c6)

Hirnantian (Late Ordovician) (c7)

Aeronian (Early Silurian) (c8)

Telychian (Early Silurian) (c9)

Wenlock (late Early Silurian) (c10)

$436 \mathrm{Ma}$
$\mathrm{cos}$

374 Ma

Cool, $\quad$ Serpukhovian (early Late Carboniferous)-Kungurian $\quad 326.4-270.6 \mathrm{Ma}$

Devonian-Carboniferous boundary (c12)

360 Ma

Tournaisean-Visean boundary (Early Carboniferous) (c13) $345 \mathrm{Ma}$

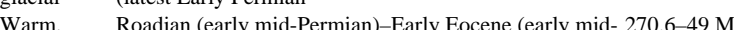
fluctuating Palaeogene)

late Pliensbachian (Early Jurassic) (c19)

Bathonian (mid-Jurassic) (c23)

late Callovian (mid-Jurassic) (c24)

Tithonian (Late Jurassic) (c25)

$164-16$

Valanginian (Early Cretaceous) (c26)

$150 \mathrm{Ma}$

late Early Aptian (Early Cretaceous) (c27)

$140 \mathrm{Ma}$

Early Albian (Early Cretaceous) (c28)
Late Albian (Early Cretaceous) (c29)

$120 \mathrm{Ma}$

Late Albian (Early Cretaceous) (c29)

$1105 \mathrm{Ma}$

mid-Cenomanian (Late Cretaceous) (c30)

$96 \mathrm{Ma}$

mid-Turonian (Late Cretaceous) (c31)

96-92 Ma

Campanian-Marl (c32) $\quad 70.6 \mathrm{Ma}$

Early Palaeocene (Early Palaeogene) (c33)

Early Eocene (mid 1 a palene (c34)

$65 \mathrm{Ma}$

Late Oligocene (Late Paloen) (c34)

$55 \mathrm{Ma}$

Late Miocene (Early Neogene) (w3)

latest Miocene-Early Pliocene (mid Neogene) (w4)

$11 \mathrm{Ma}$

mid-Pliocene (mid-Neogene) (w5) 


\begin{tabular}{|c|c|c|c|}
\hline Parameter & Proxy & Effective time range & Recent or key reference \\
\hline \multirow[t]{20}{*}{ Temperature } & $\delta^{18} \mathrm{O}$ & Archaean-Recent, but in practice only reliable from Late Cretaceous-Recent & Marshall (1992) \\
\hline & Foraminiferal $\mathrm{Mg} / \mathrm{Ca}$ & Late Cretaceous-Recent & Elderfield et al. (2002) \\
\hline & Belemnite $\mathrm{Mg} / \mathrm{Ca}$ & Jurassic-Cretaceous & Rosales et al. (2004) \\
\hline & Coralline $\mathrm{Sr} / \mathrm{Ca}$ & Late Cretaceous-Recent & Wei et al. (2004) \\
\hline & Belemnite $\mathrm{Sr} / \mathrm{Ca}$ & Jurassic-Cretaceous & Rosales et al. (2004) \\
\hline & Foraminiferal $\delta^{44} \mathrm{Ca}$ & Late Cretaceous-Recent & Gussone et al. (2003) \\
\hline & $\begin{array}{l}\text { Alkenones unsaturation } \\
\text { ratios UK'37 }\end{array}$ & Miocene-Recent & Bard (2001) \\
\hline & $\begin{array}{l}\text { Amino acid racemization } \\
\text { epimerization in molluscs }\end{array}$ & Late Pleistocene-Recent & Murray-Wallaceet al. (1988) \\
\hline & $\begin{array}{l}\text { Crenarchaeotal tetraether } \\
\text { lipids TEX86 }\end{array}$ & Cretaceous-Recent & Schouten et al. (2002) \\
\hline & Carbonate facies analysis & Cambrian-Recent & Sellwood et al. (1993) \\
\hline & $\begin{array}{l}\text { Pollen analysis using mutual } \\
\text { climatic range and climatic } \\
\text { amplitude techniques }\end{array}$ & l] Eocene-Recent & $\begin{array}{l}\text { Jimenez-Moreno et al. (2005), Klotz et al. } \\
\text { (2006) }\end{array}$ \\
\hline & $\begin{array}{l}\text { Taxonomic methods based } \\
\text { on plant macrofossils, } \\
\text { vertebrates, molluscs and } \\
\text { arthropods }\end{array}$ & Cretaceous-Recent & $\begin{array}{l}\text { Baghai \& Jorstad (1995), Friedman et al. } \\
\text { (2003), Moine \& Rousseau (2002), } \\
\text { Williams \& Eyles (1995) }\end{array}$ \\
\hline & $\begin{array}{l}\text { Nearest living relative } \\
\text { method on plant and animal } \\
\text { taxa }\end{array}$ & Early Jurassic-Recent & Wang et al. (2005), Moe \& Smith (2005) \\
\hline & $\begin{array}{l}\text { Ecological diversity spectra } \\
\text { of mammals }\end{array}$ & Pleistocene-Recent, but potentially applicable back to the Miocene & Fernandez \& Pelaez-Campomanes (2005) \\
\hline & Mammal cenograms & Eocene-Recent & Legendre et al. (2005) \\
\hline & $\begin{array}{l}\text { Transfer functions based on } \\
\text { benthic ostracods, benthic } \\
\text { and planktonic foraminifera, } \\
\text { and diatom assemblages }\end{array}$ & Pliocene-Recent & $\begin{array}{l}\text { Brouwers et al. (1991), Andersson (1997), } \\
\text { Zielinski et al. (1998) }\end{array}$ \\
\hline & $\begin{array}{l}\text { Molluscan faunal } \\
\text { assemblage analysis }\end{array}$ & Palaeocene-Recent & Kafanov \& Volvenko (1997) \\
\hline & $\begin{array}{l}\text { Climate-leaf analysis } \\
\text { multivariate program } \\
\text { (CLAMP) }\end{array}$ & Permian-Recent & Glasspool et al. (2004) \\
\hline & $\begin{array}{l}\text { Width of growth rings in } \\
\text { fossil wood }\end{array}$ & Carboniferous-Recent & Poole et al. (2005) \\
\hline & $\begin{array}{l}\text { Maximum latewood density } \\
\text { of tree rings }\end{array}$ & Recent & Briffa et al. (2004) \\
\hline \multirow[t]{8}{*}{ Salinity } & $\delta^{18} \mathrm{O}$ & Triassic-Recent & Korte et al. (2005) \\
\hline & $\mathrm{U} / \mathrm{Ca}$ ratios in corals & Pleistocene-Recent & Ourbak et al. (2006) \\
\hline & $\begin{array}{l}\text { Alkenones unsaturation } \\
\text { ratios UK'37 }\end{array}$ & Miocene-Recent & Schouten et al. (2006) \\
\hline & $\begin{array}{l}\text { Taxon analysis of } \\
\text { chironomid midges }\end{array}$ & Pleistocene-Recent, applicable only to lakes & Walker (1991) \\
\hline & $\begin{array}{l}\text { Faunal assemblage analysis } \\
\text { of insects }\end{array}$ & Cretaceous-Recent & Coram \& Jarzembowski (2002) \\
\hline & $\begin{array}{l}\text { Transfer functions based on } \\
\text { benthonic foraminifera }\end{array}$ & Pleistocene-Recent & Sejrup et al. (2004) \\
\hline & $\begin{array}{l}\text { Transfer functions based on } \\
\text { diatom assemblages }\end{array}$ & Holocene, applicable only in lakes & Roberts \& McMinn (1999) \\
\hline & $\begin{array}{l}\text { Zeolite analysis of sub- } \\
\text { glacial volcanic rocks }\end{array}$ & Miocene-Recent (potentially much further back) & Johnson \& Smellie (in press) \\
\hline \multirow[t]{10}{*}{ Circulation of oceans } & $\delta^{13} \mathrm{C}$ & Pleistocene-Recent & Lynch-Stieglitz \& Fairbanks (1994) \\
\hline & Foraminiferal Zn/Ca & Pleistocene-Recent & Marchitto et al. (2000) \\
\hline & $\begin{array}{l}\text { Foraminiferal } \mathrm{Cd} / \mathrm{Ca} \\
{ }^{9} \mathrm{Be} /{ }^{10} \mathrm{Be} \text { in manganese } \\
\text { crusts }\end{array}$ & $\begin{array}{l}\text { Pleistocene-Recent } \\
\text { Holocene }\end{array}$ & $\begin{array}{l}\text { Boyle (1988) } \\
\text { vonBlanckenburg et al. (1996) }\end{array}$ \\
\hline & $\begin{array}{l}\mathrm{Nd} \text { and } \mathrm{Pb} \text { isotopes in } \\
\text { manganese crusts }\end{array}$ & Miocene-Recent & Ling et al. (1997) \\
\hline & $\begin{array}{l}\text { Hf isotopes in manganese } \\
\text { crusts }\end{array}$ & Miocene-Recent & David et al. (2001) \\
\hline & $\mathrm{Nd}$ isotopes in foraminifera & Pleistocene-Recent & Vance \& Burton (1999) \\
\hline & $\mathrm{Ag} / \mathrm{Si}$ ratios & Recent & Zhang et al. (2004) \\
\hline & ${ }^{14} \mathrm{C}$ & Late Pleistocene-Recent & Henderson (2002) \\
\hline & ${ }^{231} \mathrm{~Pa}$ and ${ }^{230} \mathrm{Th}$ & Pleistocene-Recent & Henderson (2002) \\
\hline & Sortable silt & Palaeocene-Recent, but potentially back to the Jurassic & Pfuhl \& McCave (2005) \\
\hline \multirow[t]{9}{*}{ Productivity } & Biogenic barite & Pleistocene-Recent & Gingele \& Dahmke (1994) \\
\hline & Solubility of Th, $\mathrm{Pa}$, and Be & Pleistocene-Recent & Chase et al. (2002) \\
\hline & $\begin{array}{l}\text { Sedimentary U } \\
\text { concentration }\end{array}$ & Pleistocene-Recent & Francois et al. (1997) \\
\hline & $\begin{array}{l}\delta^{66} \mathrm{Zn} \text { ratio of manganese } \\
\text { crusts }\end{array}$ & Holocene & Maréchal et al. (2000) \\
\hline & $\begin{array}{l}\mathrm{Zn} / \mathrm{Si} \text { ratios in deep sea } \\
\text { hexactinellid sponges }\end{array}$ & Late Pleistocene-Recent & Ellwood et al. (2004) \\
\hline & $\mathrm{Mo} / \mathrm{Al}$ ratios in black shales & s Early Ordovician-Recent & Wilde et al. (2004) \\
\hline & REE in foraminifera & Untested & Haley et al. (2005) \\
\hline & $\begin{array}{l}\text { Transfer function based on } \\
\text { carbonate mass } \\
\text { accumulation rates of } \\
\text { nanoplankton }\end{array}$ & Palaeocene-Recent & Siesser (1995) \\
\hline & $\begin{array}{l}\text { Acritarch diversity analysis } \\
\mathrm{Cd} / \text { Ca ratio in foraminifera }\end{array}$ & $\begin{array}{l}\text { Proterozoic-Permian } \\
\text { Pleistocene-Recent }\end{array}$ & $\begin{array}{l}\text { Vecoli \& Le Herisse (2004) } \\
\text { Rickaby \& Elderfield (1999) }\end{array}$ \\
\hline
\end{tabular}




$$
\delta^{15} \mathrm{~N} \quad \text { Early Jurassic-Recent }
$$

$\delta^{30}$ Si of diatom silica Pleistocene-Recent

Transfer functions based on Early Holocene-Recent, applicable only to lakes

lake diatom assemblages

Carbonate alkalinity/weathering fluxes Foraminiferal Ba/Ca ratios Pleistocene-Recent

$\begin{array}{ll}{ }^{87} \mathrm{Sr} /{ }^{86} \mathrm{Sr} \text { in carbonate } & \text { Cambrian-Recent } \\ { }^{187} \mathrm{Os} /{ }^{186} \mathrm{Os} \text { in mudrocks } & \text { Jurassic-Recent } \\ { }^{87} \mathrm{Sr} /{ }^{86} \mathrm{Sr} \text { curve } & \text { Cambrian-Recent } \\ \mathrm{Ge} / \mathrm{Si} \text { ratios in diatom silica } & \text { Pleistocene-Recent } \\ \mathrm{Hf} \text { and Nd isotope ratio } & \text { ?Miocene-Recent } \\ \begin{array}{l}\text { time trajectories in } \\ \text { manganese crusts }\end{array} & \\ \begin{array}{l}\text { Clay mineralogy in ocean } \\ \text { sediments }\end{array} & \text { Triassic-Recent } \\ \begin{array}{l}\text { Mass of individual } \\ \text { foraminifera of a particular }\end{array} & \text { Late Pleistocene-Recent } \\ \text { size } & \\ \delta^{11} \mathrm{~B} \text { of foraminiferal and } & \text { Neoproterozoic-Recent, but in practice only reliable from Palaeocene-Recent } \\ \text { other carbonate } & \\ \text { calcium-ion concentration } & \text { Cambrian-Recent } \\ \text { of seawater and modelled } & \\ \text { atmospheric } \mathrm{CO}_{2} & \\ \text { concentrations } & \end{array}$

Atmospheric $\mathrm{CO}_{2}$

Precipitation/evaporation

Atmospheric circulation

Glaciation

Sea-ice cover $\delta^{13} \mathrm{C}$ of alkenones Eocene-Recent

$\delta^{13} \mathrm{C}$ of other organic Jurassic-Recent

materials

$\delta^{13} \mathrm{C}$ of marine, freshwater Devonian-Recent

or pedogenic carbonate

$\delta^{11} \mathrm{~B}$ and $\delta^{44} \mathrm{Ca}$ of carbonate Neoproterozoic-Recent

calibrated with $\delta^{18} \mathrm{O}$ and

$\delta^{13} \mathrm{C}$

Density of stomata in leaf Carboniferous-Recent

cuticle

Evaporite facies analysis Archaean-Recent

Coal, lignite and peat facies Devonian-Recent analysis

Fusain (fossil charcoal) in Devonian-Recent

clastic sediments

Palaeosols

Cambrian-Recent

Palaeocene-Recent

Transfer function from

depth to nodular, pedogenic

carbonate horizon

Clay mineralogy in ocean Triassic-Recent

sediments

Loess deposits Palaeogene-Recent

Pollen analysis using mutual Eocene-Recent

climatic range and climatic

amplitude techniques

Ecological diversity spectra Pleistocene-Recent, but potentially applicable back to the Miocene

of mammals

Mammal cenograms Eocene-Recent

Tempestite facies analysis Neoproterozoic-Recent

Windblown dust in marine Palaeogene-Recent

sediments, loess deposits

Dunes, windblown trees

Devonian-Recent

Archaean-Recent

Correlation of $\delta^{18} \mathrm{O}$ and Neoproterozoic-Recent

$\delta^{13} \mathrm{C}$ isotope excursions

and sea-level falls

Glendonite carbonate Neoproterozoic-Recent

nodules

Sub-glacial volcanic

deposits

Gibbsite concentration in Pleistocene-Recent

soils

C-25 highly branched Holocene

isoprenoid alkenes IP25

Transfer functions based on Late Pleistocene-Recent

dinoflagellate cyst

assemblages

Diatom faunal assemblages Late Pleistocene-Recent

Similarity maximum moderr Late Pleistocene-Recent analog techniques on

foraminiferal assemblages

Modern analogue

Late Pleistocene-Recent

techniques based on diatom
Reynolds et al. (2006)

Hausmann \& Kienast (2006)

Lea (1993)

Dessert et al. (2001)

Cohen et al. 2004

McArthur et al. (2001)

Jones et al. (2002)

van de Flierdt et al. (2002)

Thiry (2000)

Lohmann (1995)

Pearson \& Palmer (2000)

Royer et al. (2004)

Pagani et al. (2005b)

Hesselbo et al. (2000)

Buggisch (1991), Yemane \& Kelts (1996), Royer et al. (2001)

Demicco et al. (2003)

Thorn \& DeConto (2006)

Ziegler (2003)

Sellwood et al. (1993)

Scott (2000)

Retallack (2001)

Retallack (2005)

Ahlberg et al. (2003)

Sun \& An (2005)

Jimenez-Moreno et al. (2005), Klotz et al. (2006)

Fernandez \& Pelaez-Campomanes (2005)

Legendre et al. (2005)

Agustsdottir et al. (1999)

Kohfeld \& Harrison (2001)

Segalen et al. (2004)

Le Guern \& Davaud (2005)

Sellwood et al. (1993)

Miller et al. (2005)

Swainson \& Hammond (2001)

Smellieet al. (2006)

Ballantyneet al. (2006)

Belt et al. in press

Peyron \& De Vernal (2001)

Gersonde \& Zielinski (2000)

Sarnthein et al. (2003)

Crosta et al. (1998) 
Vaughan Figure 1

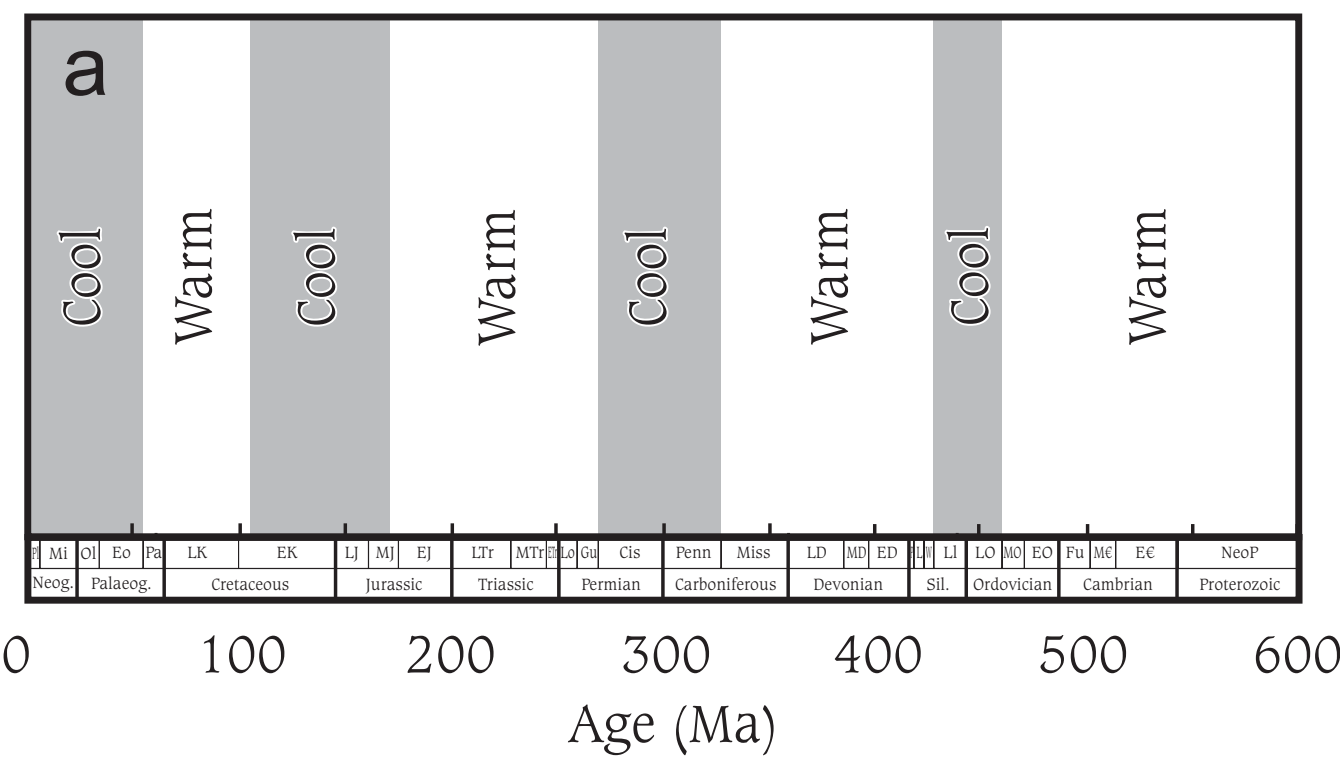

low $-\mathrm{CO}_{2} \quad$ high- $\mathrm{CO}_{2} \quad$ low- $\mathrm{CO}_{2} \quad$ high $-\mathrm{CO}_{2}$

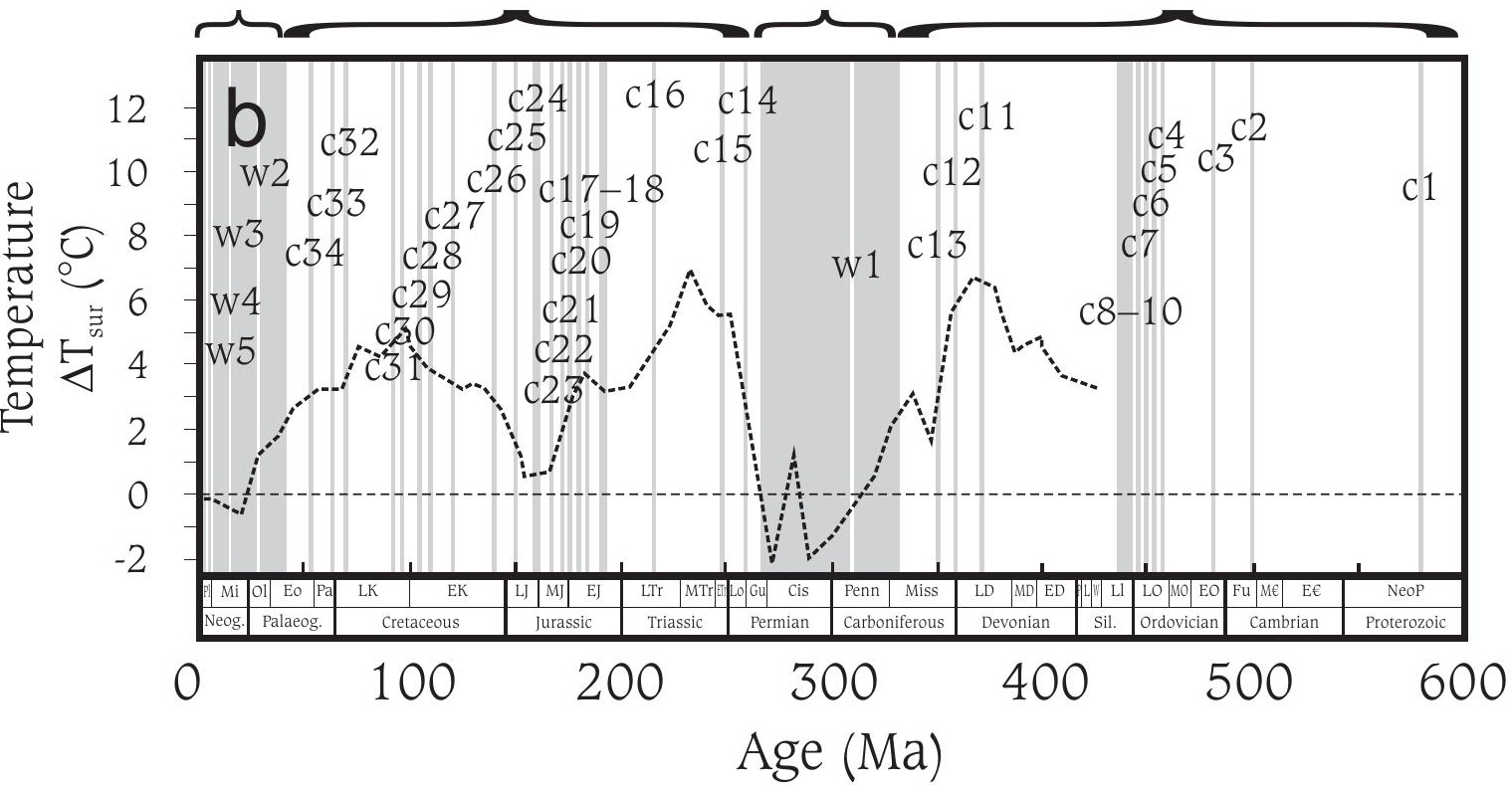


Surface Temp $\left({ }^{\circ} \mathrm{C}\right)$ Plio ${ }^{\text {Control }}$ minus Pre-Ind DJF \& JJA
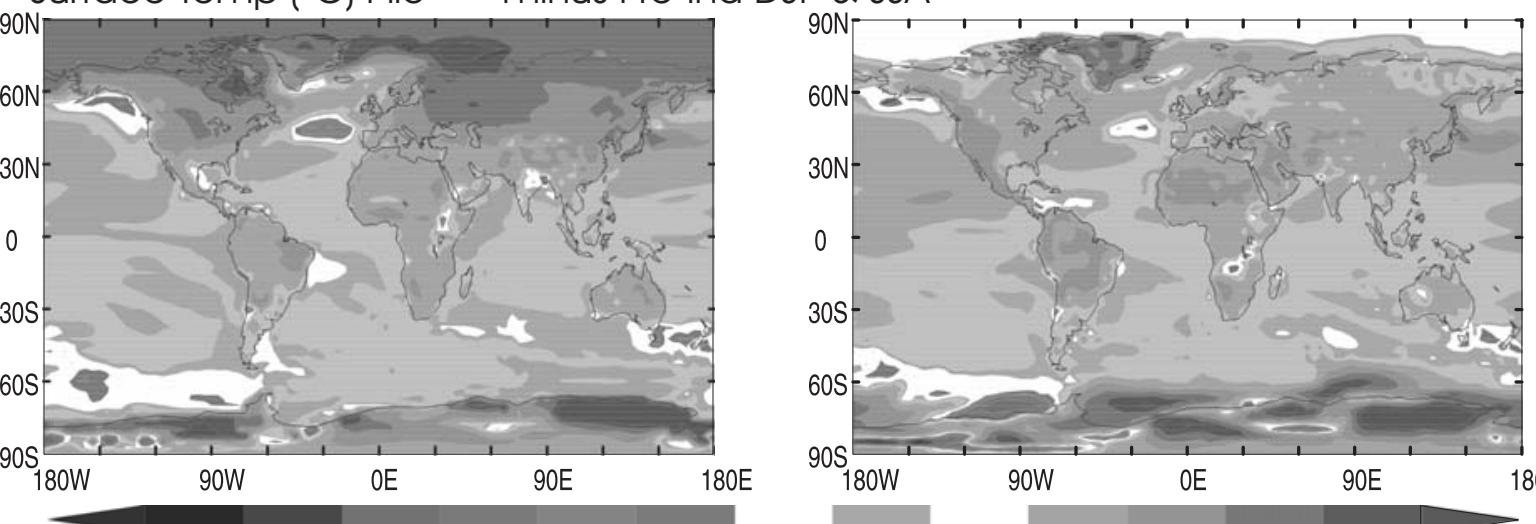
$\begin{array}{lllllll}-20 & -15 & -10 & -5 & -2.0 & -1.0 & -0.5\end{array}$

$\begin{array}{llll}0.5 & 1.0 & 2.0 & 5\end{array}$

$\begin{array}{lll}10 & 15 & 20\end{array}$ 


\section{Vaughan Figure 3}
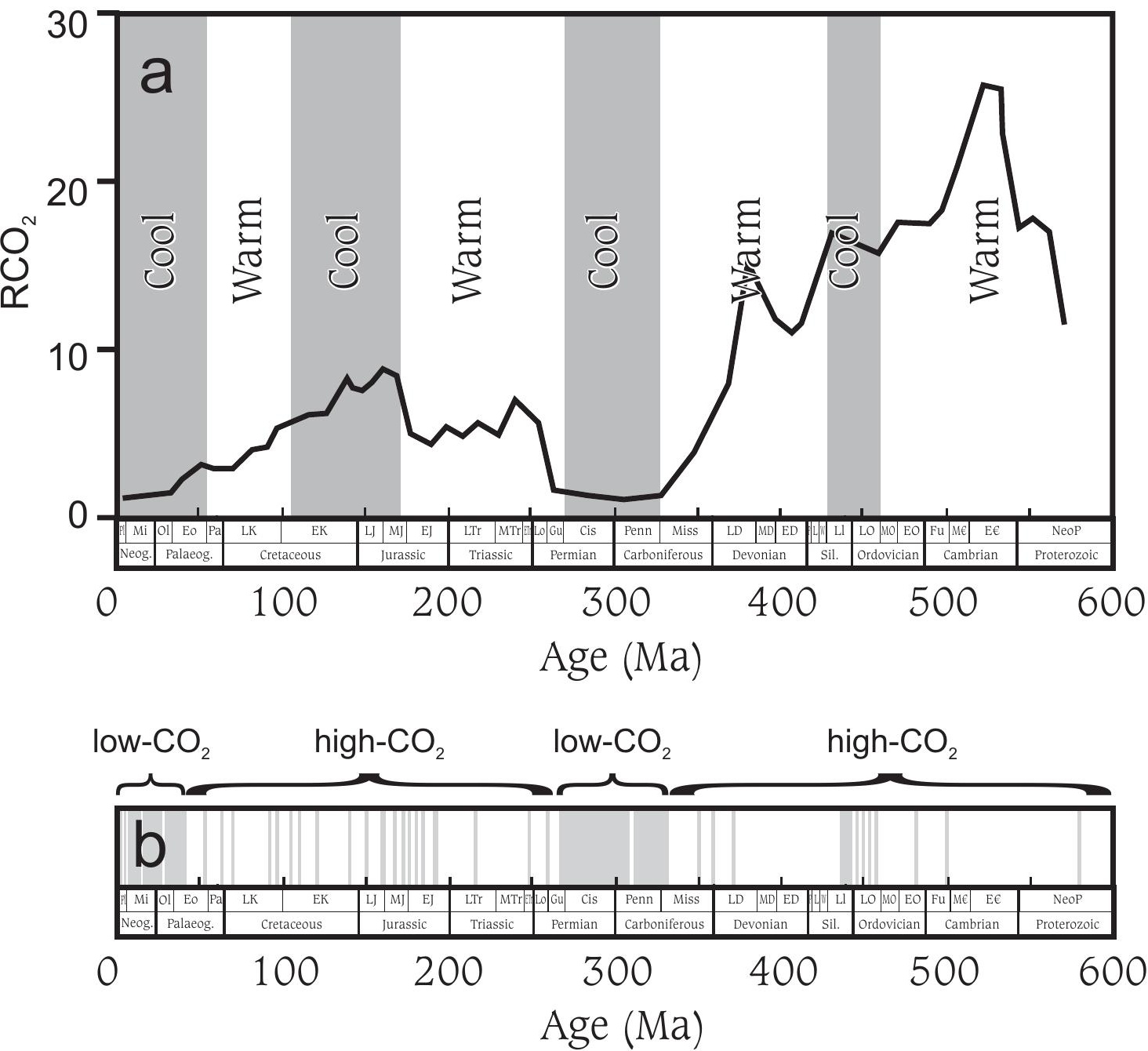
low $-\mathrm{CO}_{2}$ high- $\mathrm{CO}_{2} \quad$ low $-\mathrm{CO}_{2} \quad$ high- $\mathrm{CO}_{2}$

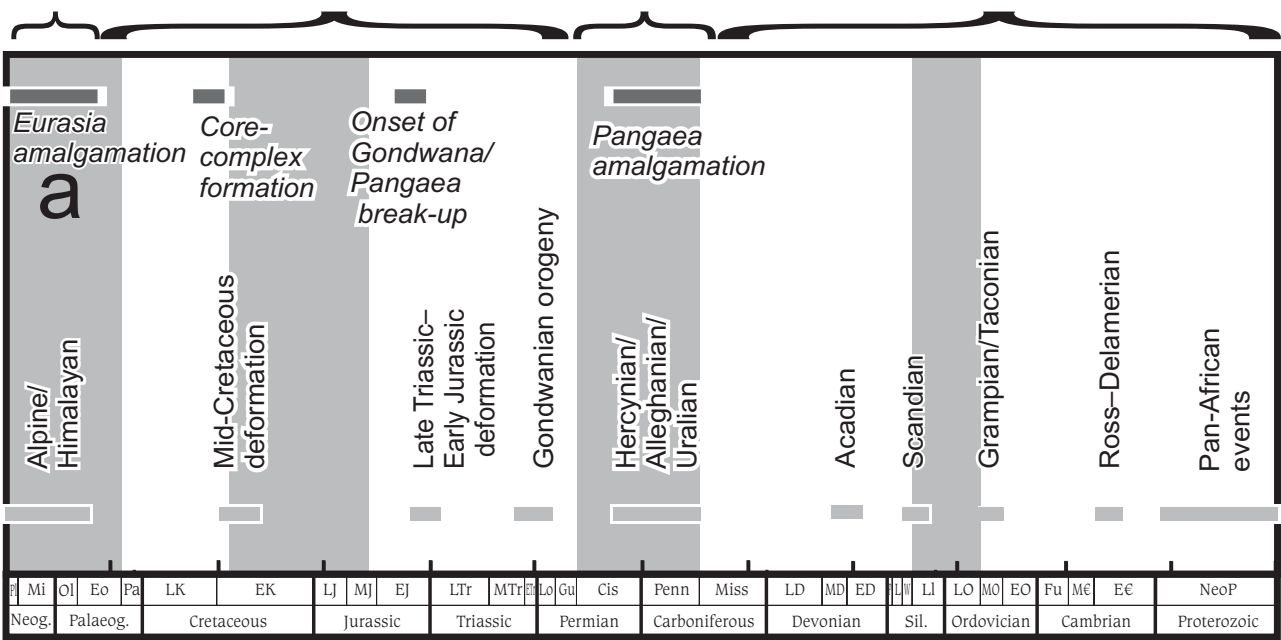

0
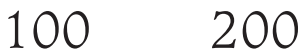

300

400

500

600

\section{Age (Ma)}

lo

high- $\mathrm{CO}_{2}$

low- $\mathrm{CO}_{2}$

high- $\mathrm{CO}_{2}$

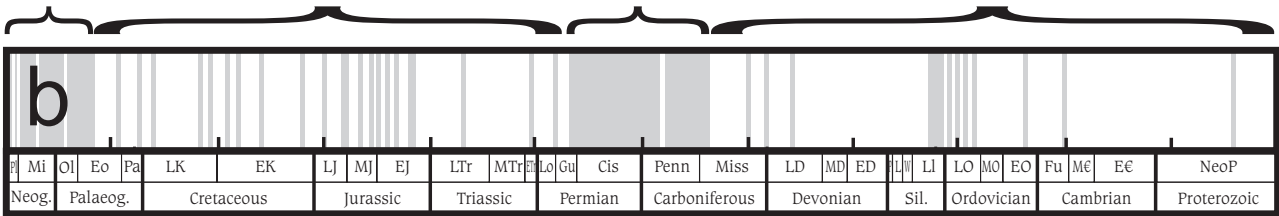

0

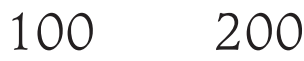

300

400

500

600

Age (Ma)

calcite

aragonite

calcite

aragonite

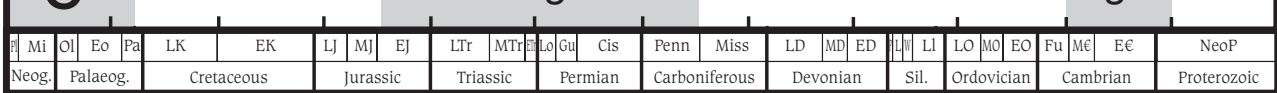

0

$100 \quad 200$

300

400

500

600 

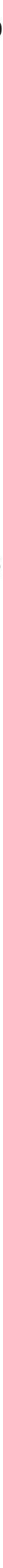
Vaughan Figure 6

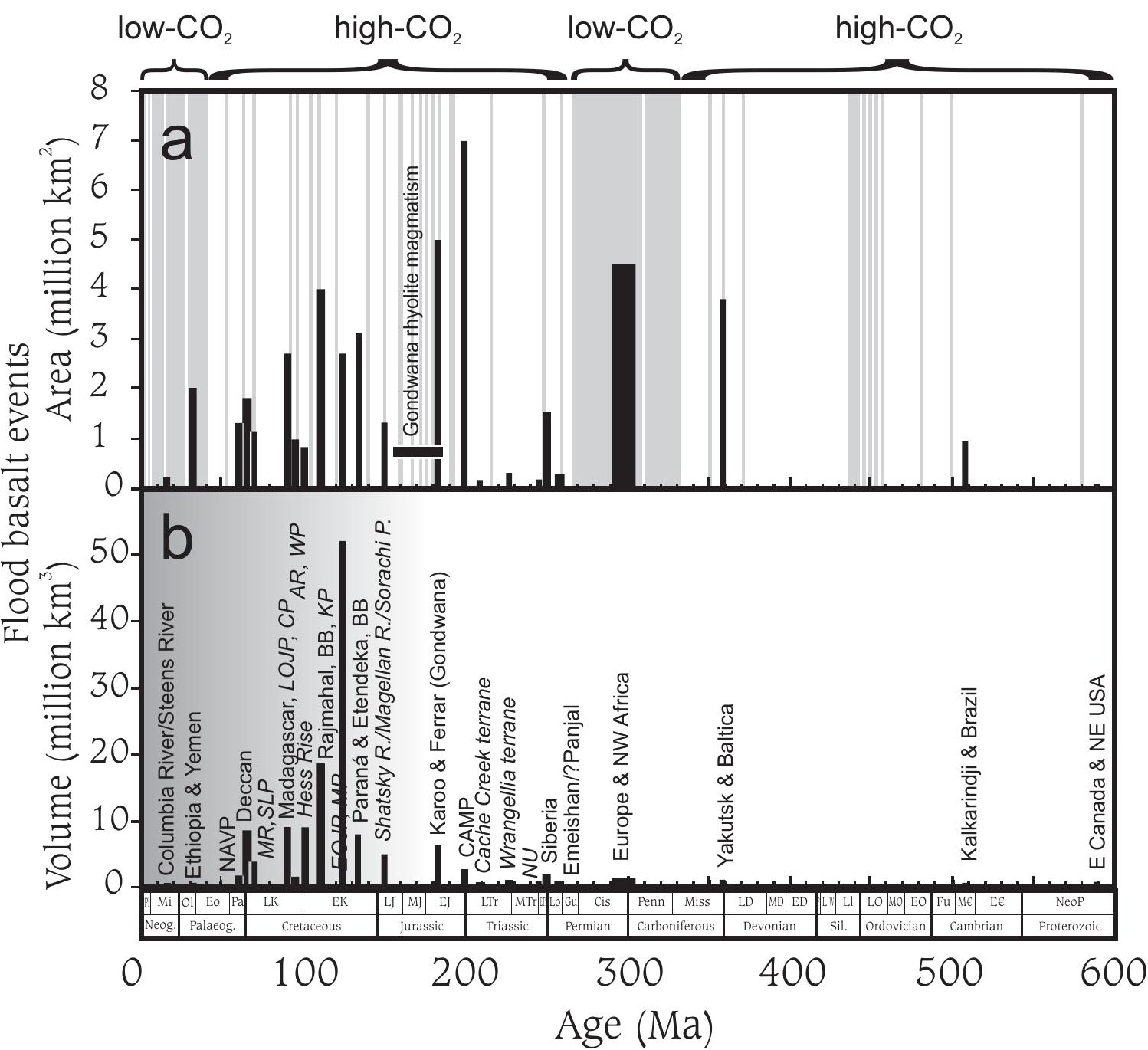


Vaughan Figure 7

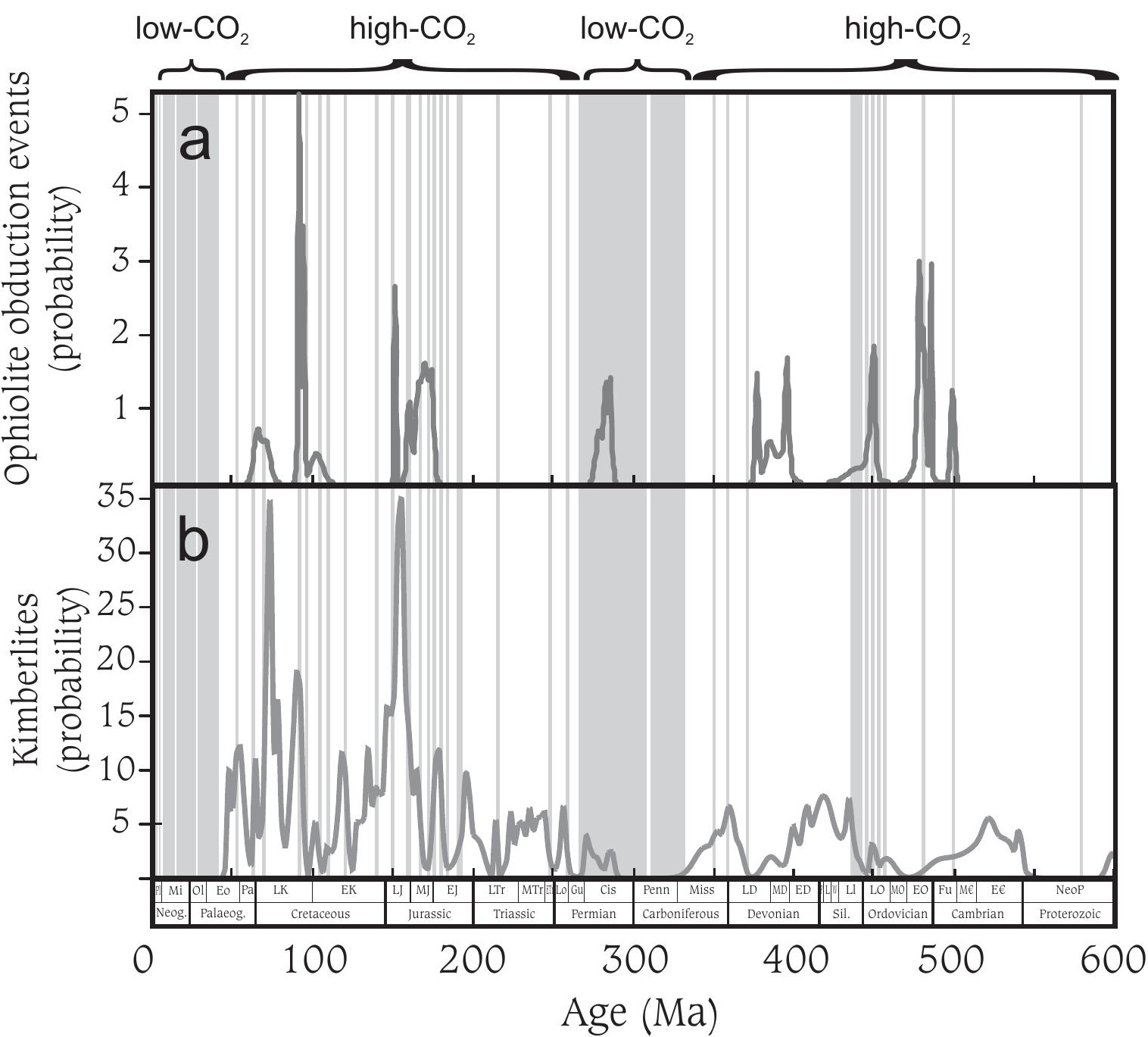


Vaughan Figure 8
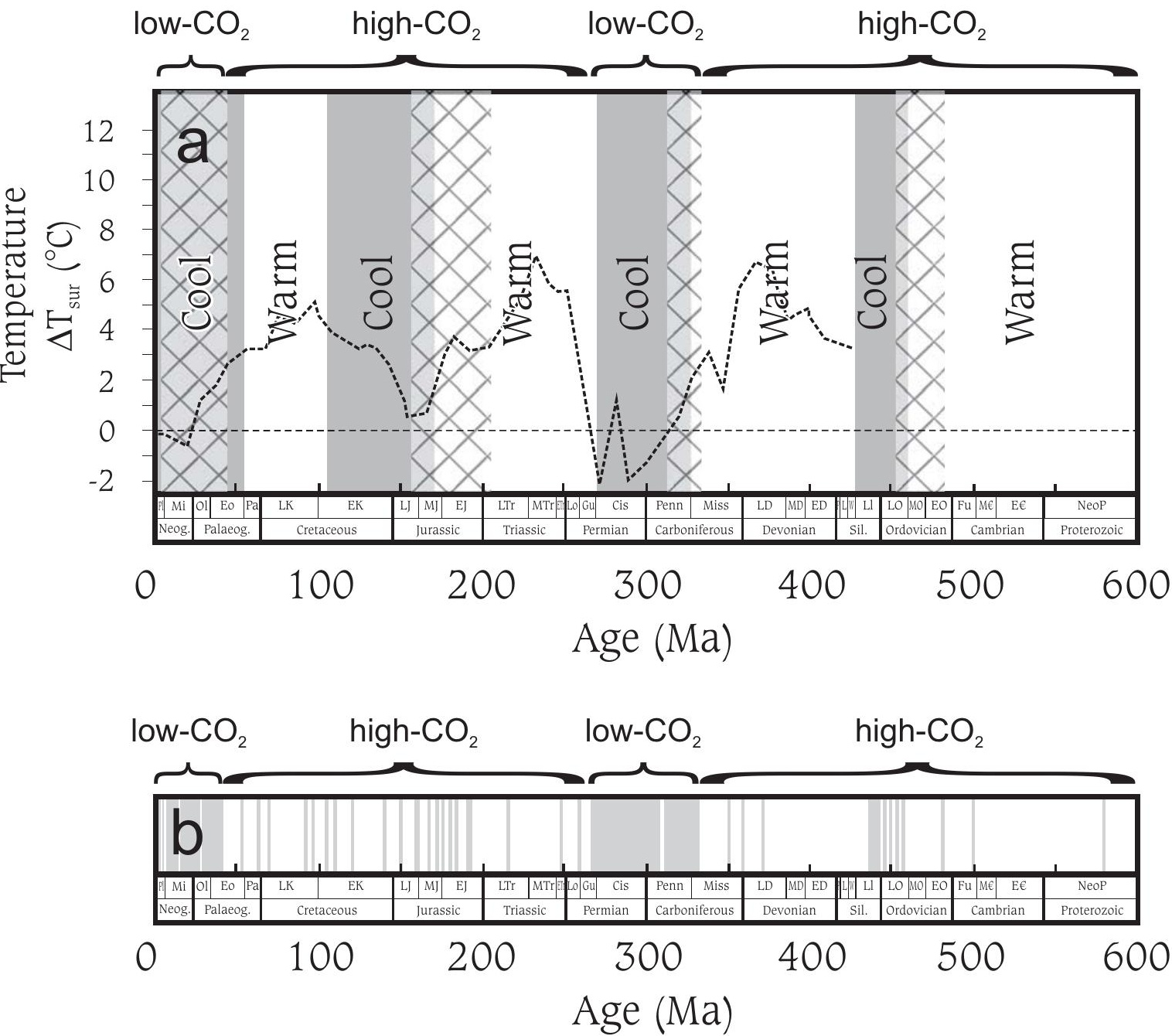